\title{
TOWARDS A NEW TOURISM: \\ A NEW TOURISM MANIFESTED ARCHITECTURALly IN DUISBURG, GERMANY
}

by:

Christina Taylor

A thesis submitted to the Faculty of Graduate and Postdoctoral Affairs in partial

fulfillment of the requirements for the degree of

Master

in

Architecture

Carleton University

Ottawa, Ontario

(c) 2014

Christina Taylor 


\section{TOWARDS A NEW TOURISM:}

A NEW TOURISM MANifESTED ARCHITECTURALLY IN DUISBURG, Germany

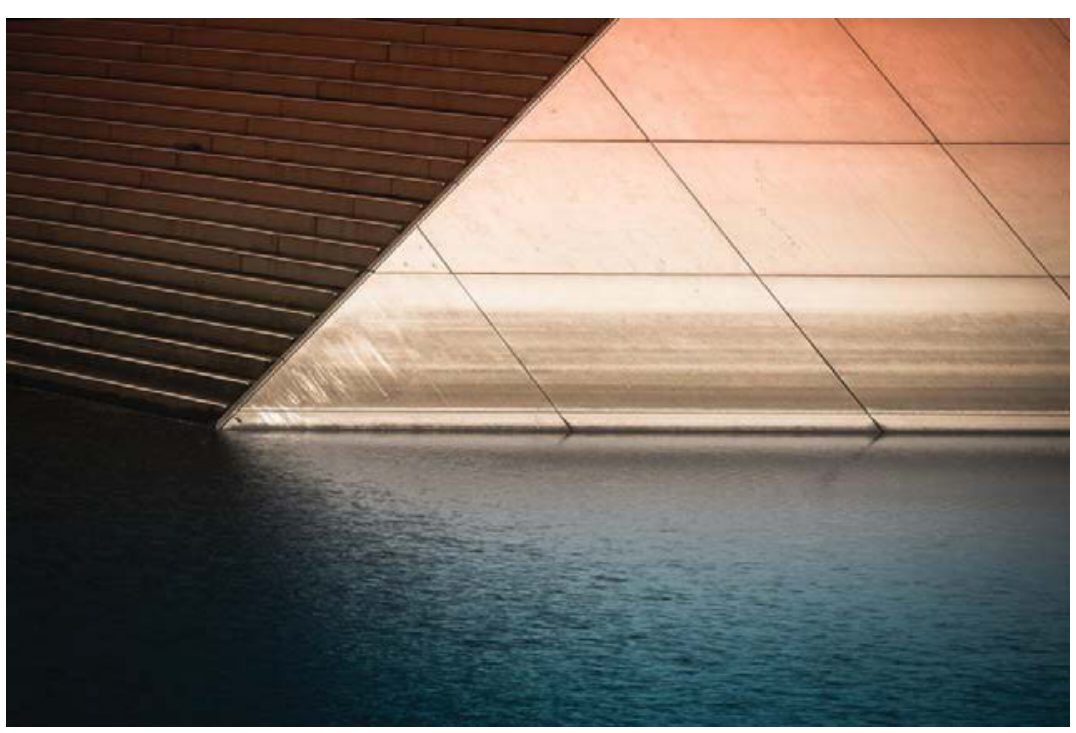

by: Christina Taylor 


\section{ABSTRACT}

The tourism industry, particularly the cruise ship industry, can be detrimental to the environment and encourages unsustainable patterns of consumption. This thesis proposes instead that this industry become a catalyst for change, working to protect the environment from which it is directly profiting from.

While the recent Slow Tourism movement (an offshoot of Carlo Petrini's Slow Food movement) is a step in the right direction, it falls short of what is needed: a new tourism model that is centered on true reciprocity, emphasizing a positive tourist contribution to the host city, its landscape and education.

This thesis is tested through the redesign of a barge and an abandoned site originally slated for a Norman Foster development in Duisburg, Germany. The intention of the design is to reverse the balance of give and take between the tourist and host city and focus on education relating to sustainable water treatment and decontamination practices. 


\section{ACKNOWLEDGEMENTS}

This thesis is dedicated to my parents, Bonnie and William Taylor, who, among many things, fostered my love for travel.

I am grateful to the faculty and staff of the Azrieli School of Architecture and Urbanism. In particular, I would like to express a very sincere appreciation to my supervisor, Lucie Fontein, for her critical eye and encouragement throughout the year.

I would like to thank my family and friends, in particular Katherine Cook for her constant support and of course countless hours of editing; Golnaz Karimi, Ardy Golshani, and Max Joon, my family in Ottawa; additionally I would like to thank all of those in the B.A.S graduating class of 2011. 


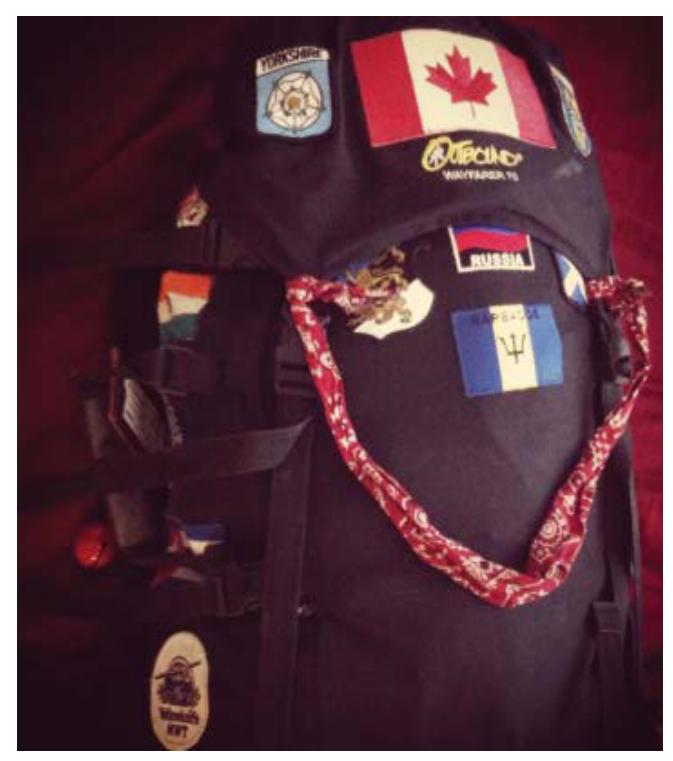

1. TALES ON A BACKPACK, C. TAYLOR, Feb 2014.

"The world is a book and he who doesn't travel only reads one page." - St. Augustine 
CHAPTER 1 - TOURISM

The Tourism Industry

The Cruise Industry

Slow Tourism

CHAPTER 2 - SITUATING THE PROJECT

The Rhine \& Ruhr Rivers

Duisburg

Innenhafen, Holzhafen

CHAPTER 3 - CASE STUDIES

Duisburg Landscape Park North

Professor Hollebone's Proposal for a living machine at Carleton University

Phytoremediation

The Living Water Gardens, Chendu, China

Viking River Cruises

CHAPTER 4 - DESIGN CRITERIA

Reciprocity

Education

CHAPTER 5 - DESIGN

Design of the Port

Design of the Barge

CONCLUSION 


\section{INTRODUCTION}

In the summer of 2012, I house-sat for a friend on a houseboat in Yellowknife Bay on Great Slave Lake. Living off the grid without electricity, waste removal, running water, or any of the conveniences the majority of Canadians have become accustomed to. I became much more aware of my lifestyle and the impact I was having on the environment. Over the short span of two weeks, I began to alter my daily habits, purchasing items in the grocery store that had less packaging, using candlelight instead of electricity produced by the generator, etc. I sat on the back dock of my houseboat and felt at ease for the first time in a long time, content with myself for how I had been living in a self-sustaining way.

Over the past five years, I have been living in and travelling to various locations around the world, never spending more than four months at a time in one location: Turkey, Australia, India, different countries in Europe. I am aware that my carbon foot print from travel alone have made me more of an environmental liability than the majority of people.

Having participated in numerous sectors of the tourist industry (cruises, bur tours, etc.), I am well aware of the detrimental role tourism can play in regards to global environmental change. However, I feel that the problematic aspects of the tourism industry should not be a deterrent to the experiences that new locations and

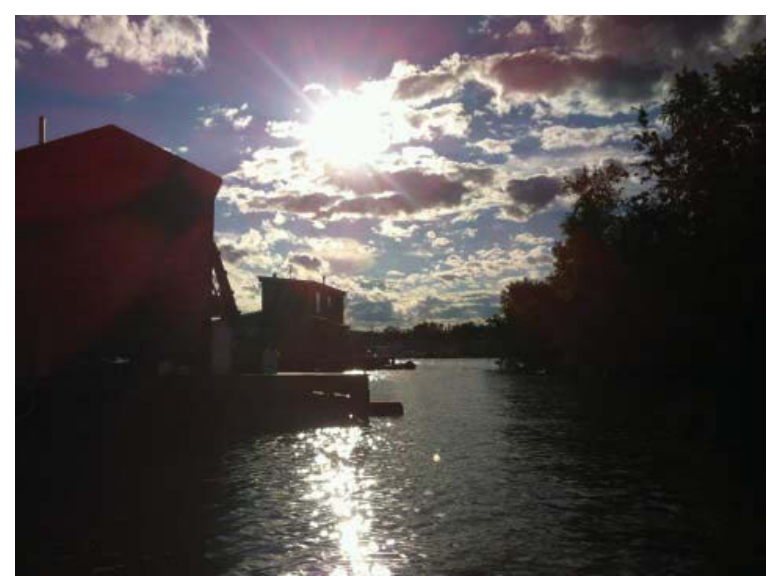

2. HOUSEBOATS UNDER THE MIDNIGHT SUN, C. TAYLOR, JULY 2012. 
cultures can provide to millions of people every year. Moreover, the tourism industry can and should be a catalyst for change, providing countries with critical sources of income, employment and development opportunities, particularly if its impacts on the environment can be minimized. With this in mind, my project will involve the redesign of a barge and an existing development in Duisburg, Germany that reverses the balance of give and take between tourist and host city, and focuses on education pertaining to sustainable water treatment practices.

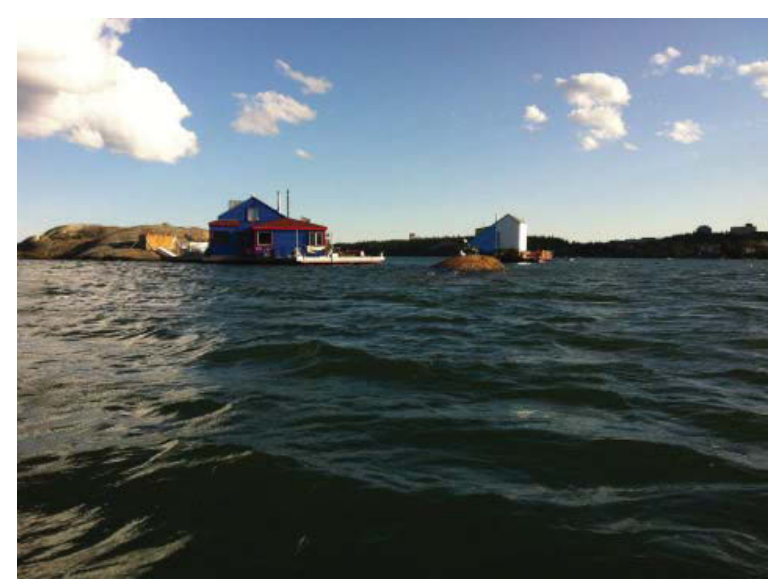

3. HOUSEBOATS ON GREAT SLAVE LAKE, C. TAYLOR, JULY 2012. 


\section{CHAPTER 1 - TOURISM}

\section{THE TOURISM INDUSTRY}

Tourism emerged as an industry during the industrial revolution in England. Since then it has continued to grow, really taking off

in popularity in the second half of the 20th century following the close of World War II. The tourist industry now represents a major economic force as well as a significant social institution. It wasn't until the 1960's and 70's that the environmental impacts of tourism were recognized as potentially harmful for individual environments at a local scale.

Environmental impacts of tourism was realized as 'local' in character -

focusing on erosion problems or beach crowding - and it was not until the publication of Swiss scientist and environmentalist Jost Krippendorf' The Landscape Devourers (1975) that the environmental impacts of tourism were perceived by a broader public in Europe. (Gossling \& Hall, 2006, p.13)

After Krippendorf's The Landscape Devourers, emphasis was placed on identifying the environmental problems that were caused by tourism on a much larger scale. During the 1980's and 1990's, as environmental issues and concerns regarding global warming became mainstream, ecotourism emerged as an influential force on the tourism market.

Gossling and Hall state that while greener tourism solutions are now available, some of the ecotourism industry partake in greenwashing. Greenwashing is when a company or industry deceptively uses marketing to convey that its products, policies or actions are environmentally responsible in order to promote itself and to generate profit. 
The word 'sustainable' is now seemingly a standard term to throw into tourism planning documents which is then seen to magically transform them into something that will make a better contributions to stakeholders. (Gossling and Hall, 2006, p.305)

While some sectors and companies are more environmentally friendly than others, it is a widely accepted fact that the tourism industry is contributing to global environmental change (please see figure 4 for the various hypothesized modes of expression of tourist development in relation to environmental quality). What is more interesting is that since the emergence of sustainable tourism the global evidence clearly demonstrates that things have gotten worse in terms of the environment. (Gossling and Hall, 2006, p.305) While the tourism industry seems to be improving as general environmental consciousness has increased over the past 25 years, it is still problematic and detrimental as a whole, promoting unsustainable patterns of consumption:

$$
\begin{aligned}
& \text { The fundamental question is whether or not tourism can prosper within } \\
& \text { a new paradigm, signified by a lower consumption of resources and } \\
& \text { substantially reduced environmental impact. This is the major challenge, one } \\
& \text { which the tourism sector is slow to address." (Gossling \& Hall, 2006, p.9) }
\end{aligned}
$$

It is unrealistic to assume that the population will refrain from participating in the tourism industry because it is detrimental to the environment. Instead it is important that not only changes in policy occur, but that fundamental changes in the industry occur to properly address the current environmental situation. Additionally it is imperative that the visibility of the current environmental issues and the effects of tourism be highlighted so that those participating in them are unable to casually ignore them. 


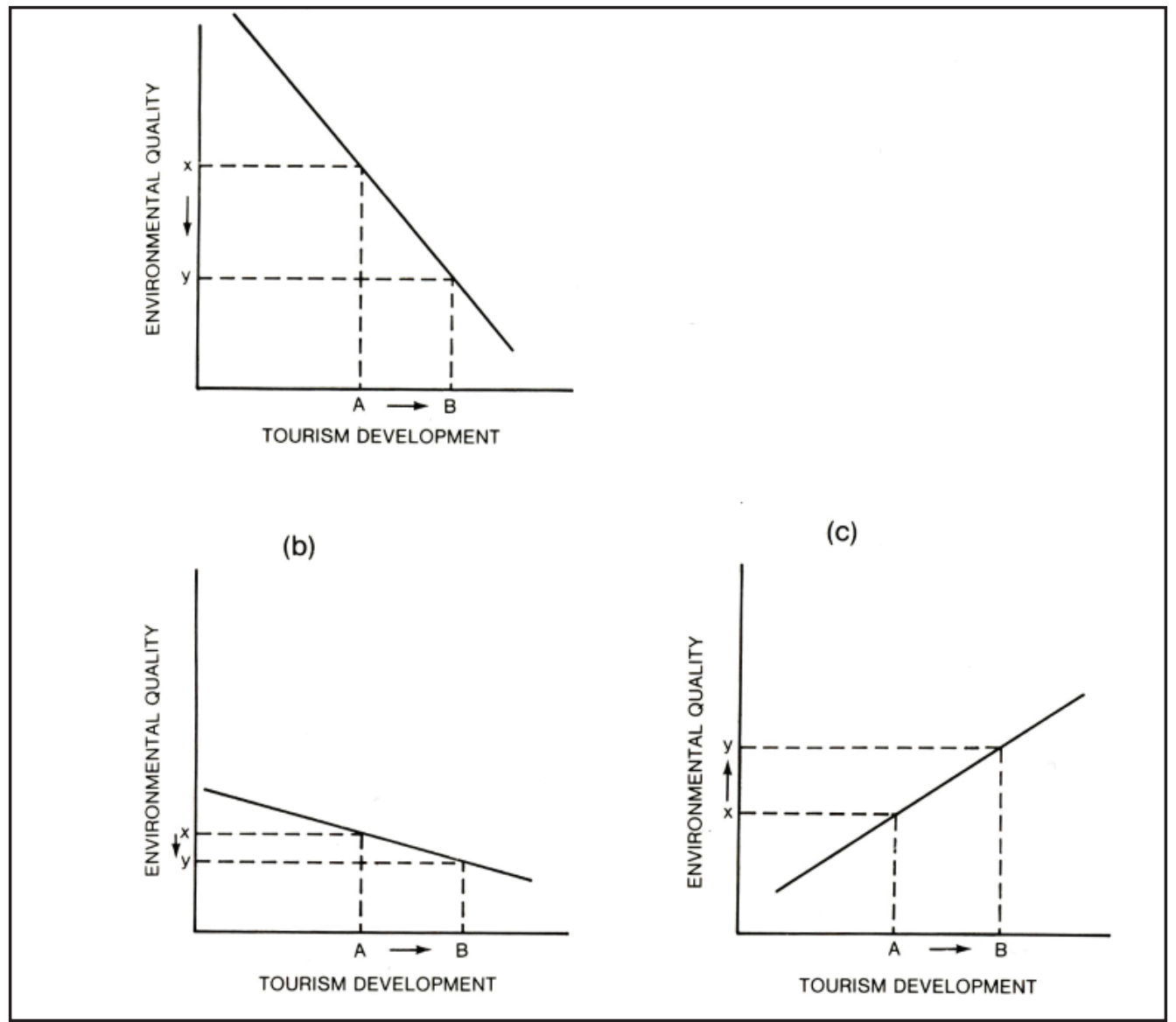

4. TOURIST DEVELOPMENT IN RELATION TO ENVIRONMENTAL QUALITY. ASHGATE. OCT 2013.

Various hypothesized modes of expression of tourist development in relation to environmental quality 


\section{THE CRUISE INDUSTRY}

Arguably the most detrimental sector of the current tourism industry is the cruise ship industry. Cruise vacations portray an image of extravagance (images 5-7) while maintaining very economically competitive prices when compared to similar onshore hotel accommodations. Despite a range of negative impacts on the environment, the cruise industry is frequently portrayed in the media as being a clean and environmentally responsible industry.

The image of a cruise vacation is idyllic. Cruise lines sell the idea of opulence and luxury while simultaneously green washing the industry through the use of multi-billion dollar a year advertising campaigns which is arguably unsurpassed by any other tourism sector... The cruise industry enjoys an image that is more positive than deserved. This is in part a product of collectively spending more than a billion dollars a year on advertising and public relations....The Industry also spends millions of dollars on lobbying federal and state/provincial governments and on political campaigns at all levels, including local port commissions. It effectively promotes itself and its interests and is efficient at countering messages it views as threatening to its clean and responsible image. (Klein, 2008, p.1)

This costly blend of public relations and lobbying seeks to hide the detrimental impacts of cruise ships on the environment. At the top of this list is the discharge that is created and dumped into the world's oceans. Cruise ships operate under relaxed rules and regulations which are rarely followed or enforced.

Operating on a much smaller scale than the large seafaring cruise vessels are river cruises, which operate primarily in Europe and Asia. While river cruises operate under much stricter regulations than those established for the large ocean cruise lines, and are

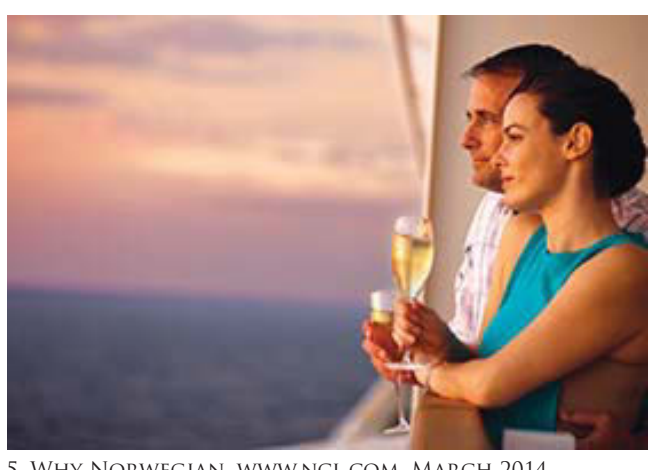

5. WHY NORWEGIAN, WWW.NCL COM. MARCH 2014.

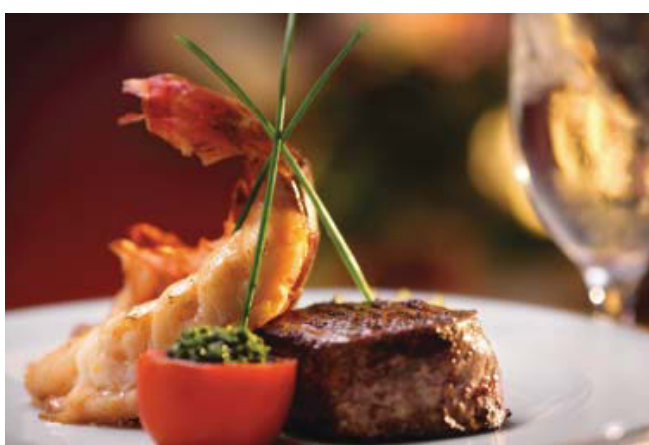

6. WHY NORWEGIAN, WWW.NCL.COM, MARCH 2014.

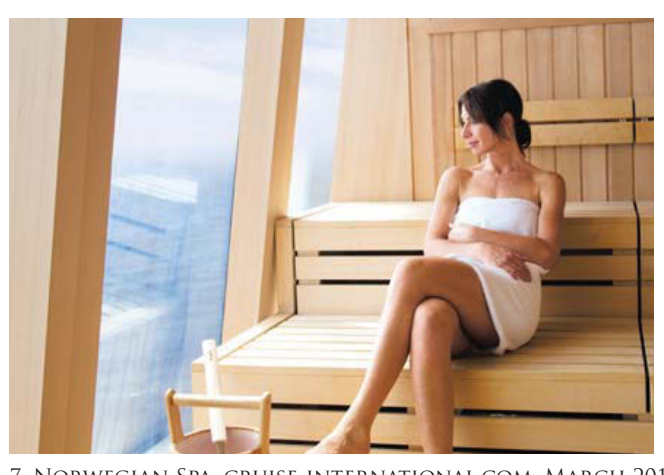

7. NORWEGIAN SPA. CRUISE-INTERNATIONAL.COM, MARCH 2014 
less damaging to the environment due to the smaller scale of the industry and boats themselves, there are some problematic issues that both the river cruise industry and the larger ocean cruise industry share. Cooper notes the similarities between the over indulgent experience and image of extravagance, "River cruises can offer a style of luxury similar to that found on large ocean cruise ships including swimming pools, saunas, fitness centers, spas, hair and beauty salons, library and media rooms." (Cooper, 2012, p.105)

As mentioned above, the most important issue that any floating vessel needs to address is the waste produced while on the water. Black water emissions consist primarily of sewage, which contains bacteria, pathogens, diseases, viruses, intestinal parasites and harmful nutrients. (Klein, 2008, p.52)

If not adequately treated [black water] can cause bacterial and viral contamination of fisheries and shellfish beds. In addition nutrients in sewage such as nitrogen and phosphorus promote algal growth. Algae consume oxygen in the water, which can be detrimental or lethal to fish and other aquatic life. (Klein, 2008, p.52)

Current regulations in the United States allow for treated waste to be dumped wherever convenient and untreated waste to be dumped at least three miles off shore.

Although not as toxic as black water, grey water is another biproduct of cruise-based tourism. Grey water consists of wastewater from showers, sinks, laundry as well as cleaning activities and is the largest source of liquid waste, with as much as 350 liters produced per day per person. (Klein, 2008, p.63) Until recently,

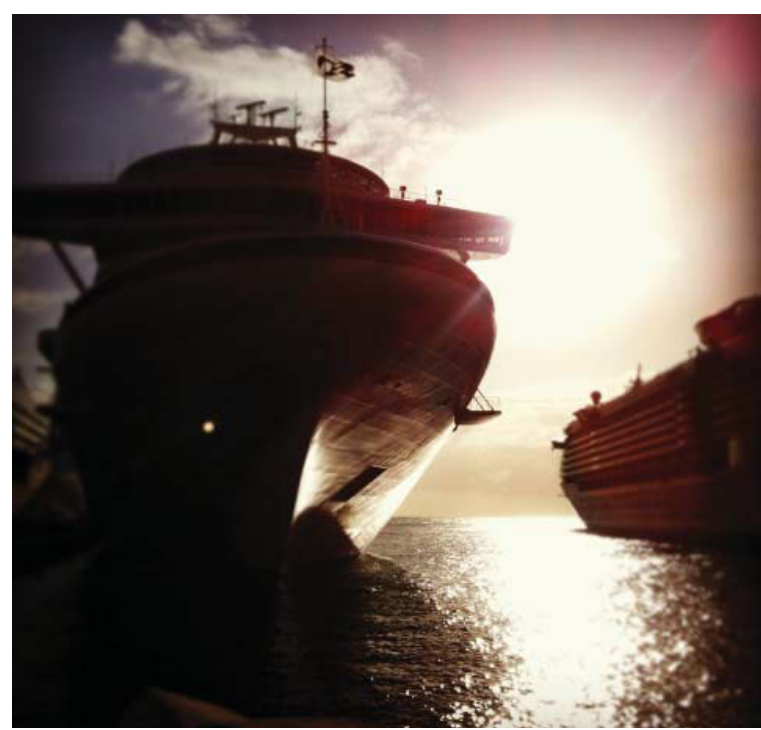

8. PRINCESS SHIP DOCKED AT ST. MARTIN, C. TAYLOR, JAN 2014. 
ships were uniformly designed with grey water piping emptying directly from the ship. Although not regulated or uniform, cruise ships typically hold grey water in a tank, and then filter solids and plastics before discharging into the surrounding waters. Apart from Alaska and fresh water systems in the United States, there are few or no regulations regarding grey water discharge emissions. According to the Environmental Protection Agency grey water discharge contains an unexpectedly large number of pollutants and its negative impacts on the earth's oceans are drastically underestimated:

Untreated ship gray water concentrations exceeded EPA standards for discharges from Type II MSDs (for fecal coliform and total suspended solids). In addition, untreated gray water concentration exceeded all wastewater discharge standards under Title XIV for continuous discharge from cruise ships in Alaska, and secondary treatment discharge standards from landbased sewage treatment plants. (EPA, 2007)

Cruise ships further produce a wide variety of hazardous wastes. These include oily bilge water, processing chemicals, dry cleaning waste, used paint, solvents, heavy metals, expired chemicals and pharmaceuticals, hydrocarbons, chlorinated hydrocarbons, used fluorescents and mercury vapor light bulbs and batteries. (Klein, 2008, p.55) The toxicity levels of these substances make them a major environmental concern.

A typical large cruise ship will generate an average eight metric tons of oily bilge water for each twenty-four hours of operation. According to Royal Caribbean's 1998 Environmental Report its ship produces an average of 25,000 gallons of oily bilge water on a one week voyage. (Klein, 2008, p.55)

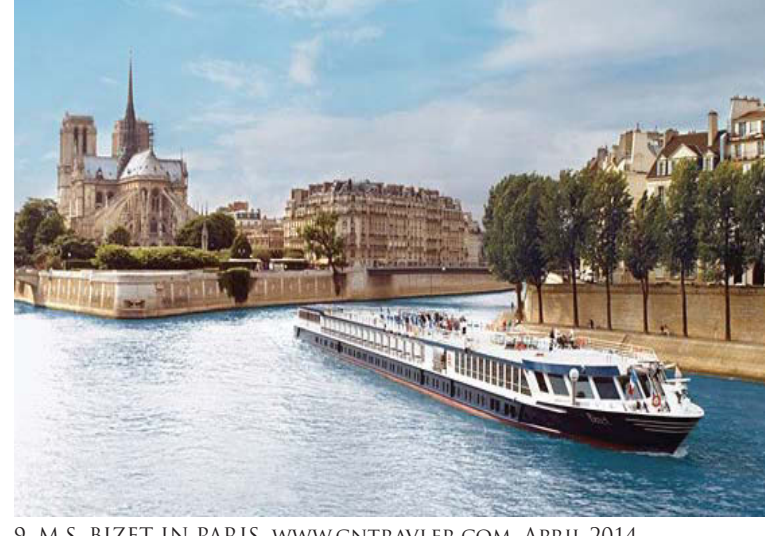

9. M.S. BIZET IN PARIS. WWW.CNTRAVLER.COM. APRIL 2014 
Oil and water collects at the bottom of the boats hull along with other toxic materials such as metal shavings, paint, glass, cleaning agents and ballast water. As the leading source of invasive species in U.S. marine waters, toxic emissions, ballast water and oily bilge water are highly detrimental to ocean and marine life, the environment, and public health. (Klein, 2008, p.58)

While there are regulations governing the discharge of hazardous waste, and oily bilge water, much like black and grey water discharge, they are rarely enforced and numerous ocean cruise lines have been found in violation of such regulations. There are monetary incentives for disobeying regulations. The machine that separates oily water is extremely expensive and requires a minimum of $\$ 80,000$ (USD) in upkeep per annum. It is within the cruise lines best financial interests to pay occasional fines associated with breaking the rules and regulations instead of following them.

Collectively from 1998 through 2002 the three corporations (Royal Caribbean Cruise Line, Norwegian Cruise Line, and Carnival Corporation) paid

fines and restitution of $\$ 50$ million for discharge (or falsifying records to

conceal discharging) oily bilge water and hazardous waste. (Klein, 2008, p.56)

Although the River cruise industry hasn't received nearly as much bad press when compared to large ocean faring vessels, this does not necessarily mean that it is acting in the environment's best interest. As Cooper notes, "compared to the research and industry attention that ocean cruising has attracted recently; rivers have apparently been of little interest to tourism academics and environmentalist." (Cooper, 2012, p.2) While not as damaging comparatively, river cruises are not innocent players either. Butt 
estimates that on average 20-40 litres of black water is produced per person everyday on river cruises in Europe. (Butt, 2010) And while current regulations set in Europe do not allow for vessels to dump any hazardous waste into the rivers they travel on, this does not necessarily mean that wastes (both water and solids) are being treated correctly;

\section{What happens to the waste once it is landed is, in most cases, outside the control of the ship or the ship-owner. In Europe, for example, the waste service of the port is responsible for the waste, and it is up to this company to decide its final destination. Usually waste is dealt with based on what the most economical solution for the port is, not necessarily what is the most environmentally responsible solution.( Hunt, 2010)}

Although relatively little is known about river cruising's potentially damaging effects on the environment because of the seemingly inconsequential effects of a much smaller industry, Cooper acknowledges that the river cruise industry is growing rapidly in popularity and becoming more influential on the water quality of the rivers traveled on.

In recent years, there has been growing interest in river cruising in Europe. Between 1996 and 2003, the numbers of river cruise passengers in Germany increased by $168 \%$. River cruises are important but surprisingly neglected aspect of the global tourism industry. Yet rivers form the basis for many of the ecosystems that underpin ecotourism and other recreational activities, in addition to providing water to sustain urban growth, farming, agriculturerelated experiences such as viticulture and the transport of goods and people. (Cooper, 2012, p.2)

With the river cruise industry on the rise, it is important that mistakes made by the ocean cruise industry are avoided. The sustainability of the river cruise industry relies on a balanced approach of responsible planning and management of the natural

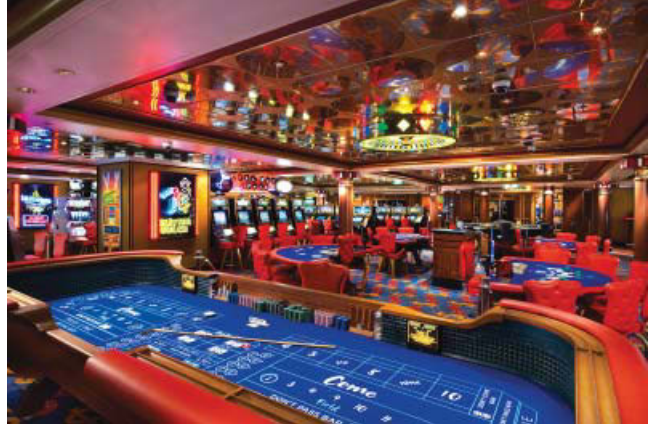

10. NCL CASINO, WWW.NCL.COM, MARCH 2014.

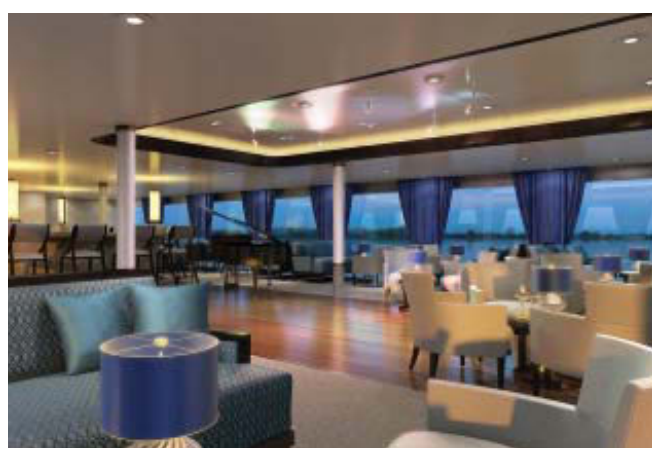

11. VIKING'S LUXURY INTERIOR, WWW.FROMTHEDECKCHAIR. COM, MAY 2014 
tourism resource, in order to prevent detrimental effects in the future.

Both the ocean cruise industry and the river cruise industry should be catalysts for change with respect to protecting the environment from which it profits directly. Green technologies are now widely available; there is no excuse for the current state of both industries. There must be not only a drastic shift in the physical aspects of the cruise industry (the ships themselves) but first and foremost there must be a shift in the mentality of the industry and travelers alike. Issues of visibility and awareness must be brought to the attention of travelers. These are issues that can be addressed through design. 


\section{SLOW TOURISM}

In contrast to the cruise industry and mainstream tourism there has been a push for a more eco-friendly way of approaching travel. Critical to the understanding of slow tourism is the Slow Food and Slow Cities movements, where slow tourism has its roots. The Slow Food and Slow Cities movements began in Italy in the 1980's with Carlo Petrini's protest against the opening of a McDonald's restaurant in a culturally significant area of Rome. In direct opposition to fast food, the Slow Food movement promotes the use of local ingredients as well as traditional recipes and methods of cooking. The Slow movement places emphasis on slowing the pace as a positive step both for the individual and society.

Being slow was once an entirely derogatory term that signified one's inability to 'keep up' in the competitive spheres of work and leisure. Yet curiously, the meaning of slow is now starting to shift, as slowness today has invoked a credible metaphor for stepping off the treadmill, seeking work-life balance or refusing the dominant logic of speed. Slowing down has become an antidote to the fast-paced global imperatives of global capitalism that urge the entrepreneurial self to speed up, become mobile and work harder in order to be valued as a successful, productive and conspicuous consumers (Fullagar et al., 2012, p.20)

Since the 1980's, the Slow Food movement has expanded to 132 countries and there are 100,000 members of the Slow Food International Organization (Fullagar et.al, 2001, p.3). The Slow movement encompasses numerous disciplines, including but not limited to: gardening, money, parenting, art, media, fashion, science, church, and counseling. More recently the Slow Tourism movement has begun to gain momentum and popularity. 
In contrast to a more traditional model of travel, Slow Tourism places emphasis on the sensory embodiment of the journey, as well as traveling shorter distances. Slow Tourism recognizes the inherent problematic fast-paced, ecologically damaging aspects of traditional tourism, and supports a more genuine level of community engagement for the traveler. Advocates for Slow Tourism suggest that, "visiting fewer destinations and staying longer in each location can assist slow tourists in their search for quality, deep, rich experiences instead of trying to see as much as possible superficially." (Fullagar et.al, 2001, p.87) Slow Tourism places emphasis on a genuine experience of a location and a shift away from the unsustainable levels of consumption that are present in the traditional model of tourism.

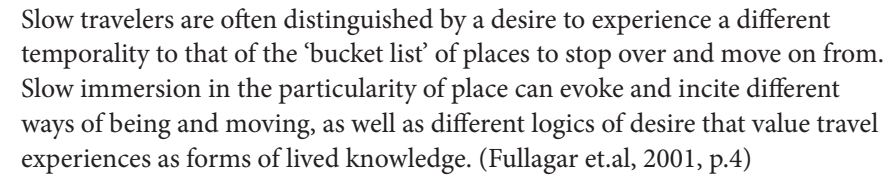

At the core of the Slow Tourism ideology is an emphasis on a responsible or ethical way of travelling with concern for the environment. There is a shift away from unsustainable levels of consumption present in the traditional mode of tourism and emphasis is placed on making positive contributions to the local environment. Slow Tourism emphasises that travel should not be at the expense of or have a negative impact on the environment; rather it should be in tune with the ecology of the area.

Slow travel is about making conscious choices, and not letting the anticipation of arrival undermine the pleasure of the actual 
journey. While Slow Tourism lacks a formal definition, various principles have been compiled and are meant to serve as a guide for Slow Tourism.

\section{Principles of Slow Tourism}

1. Start at home. The key to slow travel is a state of mind. That can be developed at home.

2. Travel slow. Speed destroys the connection with landscape. Slow travel restores it.

3. You may eagerly look forward to the arrival at your chosen destination, but do not let that anticipation eclipse the pleasure of the journey.

4. Check out local markets and shops.

5. Savor café culture. Sitting in a café, you become part of the cityscape and not merely a passing observer.

6. Take time to get a feel for the languages and dialects of the areas you visit. Learn a few phrases, use a dictionary and buy a local newspaper.

7. Engage with communities at the right level. Choose accommodation and eating options that are appropriate to the area where you are travelling.

8. Do what the locals do, not only what the guidebooks say.

9. Savor the unexpected. Delayed trains or missed bus connections create new opportunities.

10. Think what you can give back to the communities you visit.

(FULLAGAR ET AL, 2001) 
From the slow travel perspective, there is ongoing debate regarding the position of water-based travel within the slow paradigm: On the one hand, the connection to water is seen as an asset for meaningful travel:

Travel across water is relatively time-consuming and thus provides a platform for travel-based experiences. All forms of water-based travel have in common an engagement with water, whether this is the ocean, a lake or a small river. Given the importance of water to human survival it is a landscape feature that evokes a strong response. (Fullagar et.al, 2001, p.159)

However, the environmentally-detrimental nature of luxury cruise ships and its limited location encounters are inherently in direct opposition to Slow Tourism. While there is the potential for interaction with the crew and other passengers, and the opportunity to experience culture aboard the ship, time restraints spent at each port limit engagement with the culture of each location. As a result, ships become, "destinations in themselves and ports of call, in many cases, have become secondary, while the onboard experience is carefully managed." (Dickenson, 161) While travellers may partake in the cruise culture, it is an experience that is entirely fabricated, heavily staged, and in stark contrast to the values of slow tourism.

Alternative forms of travel aboard ships do fall within the parameters of Slow Tourism. While travelling via a commercial ship is relatively unknown to the general public, it is an economical mode of transportation. It also provides unique experiences:

Travelling on a cargo vessel is different to a typical cruise. While cabins are of a high standard, there is much less in the way of recreational 
Cruising as a cargo ship passenger is also a more environmentally viable option as the ship would be making the trip regardless of the additional passengers. The primary purpose of the ship is to transport cargo; including extra passengers to fill the ship does not alter the impact on the environment. Given the slow nature of the trip, the authentic experience that is offered, and the smaller ecological footprint, cargo ship cruising demonstrates that waterbased travel can encapsulate and embrace important aspects of Slow Tourism.

This thesis proposes to embrace the principles of Slow Tourism, but actually challenge the tourism industry to go even further. The proposed design will demonstrate that the tourism industry can do more than simply encourage authentic participation in local life. It can positively contribute to the host city by introducing a heightened awareness of the environment.

Redesigning an existing barge that is no longer in use and incorporating environmentally responsible design principles learnt from houseboat living make it possible to design a cruise vessel and port that not only adhere to the principles of slow tourism, but also serve as a model for new and bolder designs of eco-friendly ports and water based travel.

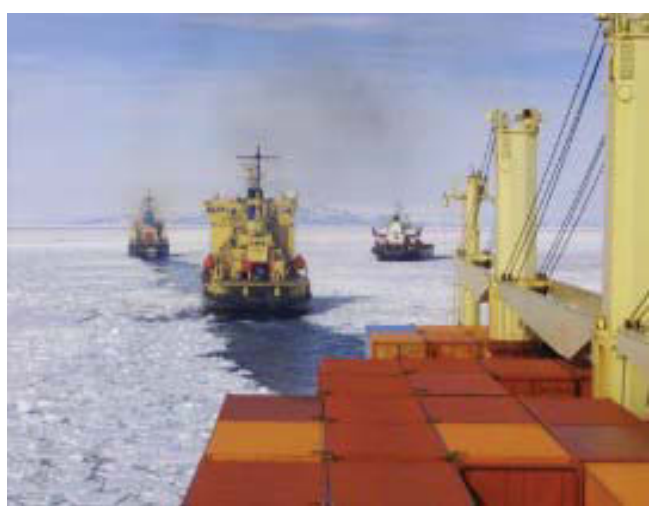

12. Cargo Ship, Flightlesstravel.com, March 2014. 


\section{THESIS QUESTION}

The River Cruise Industry has the potential to offer a new form of tourism that draws inspiration from the slow tourism movement but takes it a step further. Specifically how can a new tourism model that places greater emphasis on reciprocity and environmental education manifest itself architecturally along the Rhine River in Duisburg, Germany? 


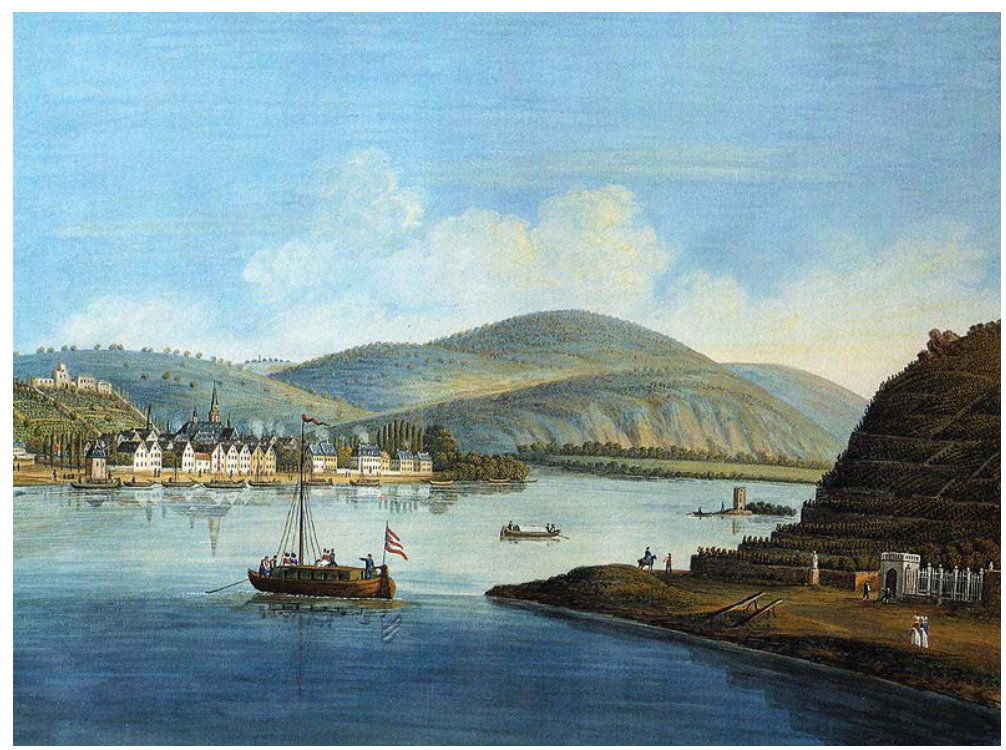

13. RHINE RIVER AND BINGEN. HTTP://WWW.WIKIPEDIA.COM. MARCH 2014.

The Rhine is the river about which all the world speaks but no one studies, which all the world visits but no one knows, which one sees as it passes but forgets as it flows, which everyone skins but no one plumbs. Still, its ruins lift the imagination and its destiny preoccupies serious minds; and below the surface of its current, this admirable river reveals to the poet and statesman alike the past and future of Europe. -Victor Hugo 


\section{CHAPTER 2 - SitUATING THE PROJECT}

\section{THE RHINE \& RUHR RIVERS}

Pollution of rivers in urban regions are caused by human, landbased activities which increased significantly with the start of the Industrial Revolution. Once dubbed Europe's romantic sewer, the Rhine is no exception. The 1250 kilometer long river is of vital significance for Western Europe, given the countries and tributaries it connects as well as the density of population located along its banks (approximately 40 million). (Hueting et. al., 1978, p.29) As Europe's undisputed busiest waterway, flowing from the Swiss Alps through France, Germany to the Netherlands (figure 14), the Rhine transports an average of 200 million metric tons of goods annually. (Cioc, 2002, p.24)

The Rhine has a long history of contamination and pollutants, which began with the steady increase of the population along the river coinciding with the industrial revolution. The pollution of the Rhine can be partially attributed to local governments and regional policies, and their slow reaction to industrial growth. Local governments were afraid that implementing restrictions would slow the pace of industrial growth and therefore be detrimental to local industries and economies. One of the greatest sources of pollution is the rust belt located on the Ruhr River, a substantial tributary that drains into the Rhine at Duisburg. The Ruhr is synonymous with coal, iron and steel:

Coal and iron transformed the Rhineland-Westphalian region from an agrarian to an industrial landscape in a remarkably short time. By 1900, mines, factories, and smokestacks filled the space where only a few decades earlier trees, birds, orchards, grains, and root crops (principally potatoes)

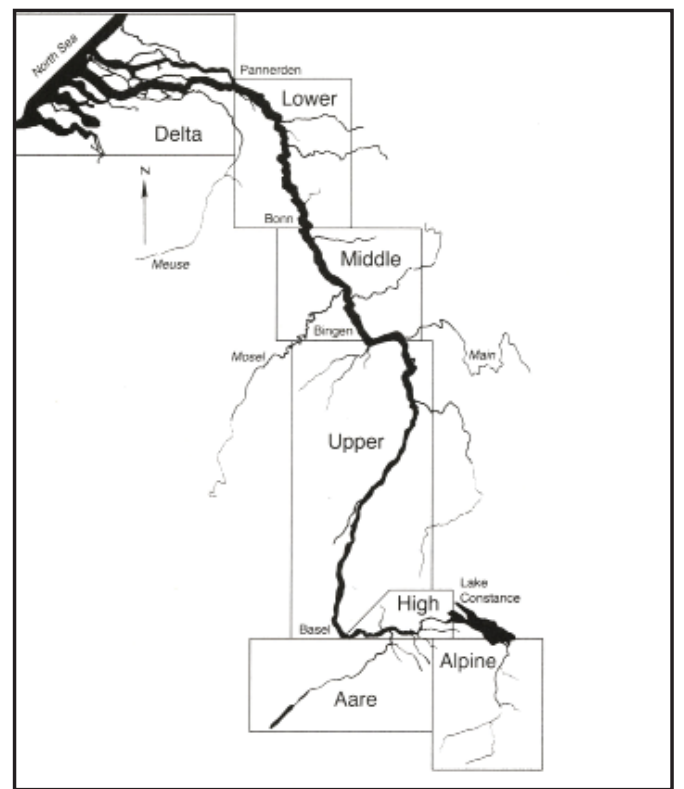

14. Full MAP OF THE RHINE, CIOC 1, NOV 2013.

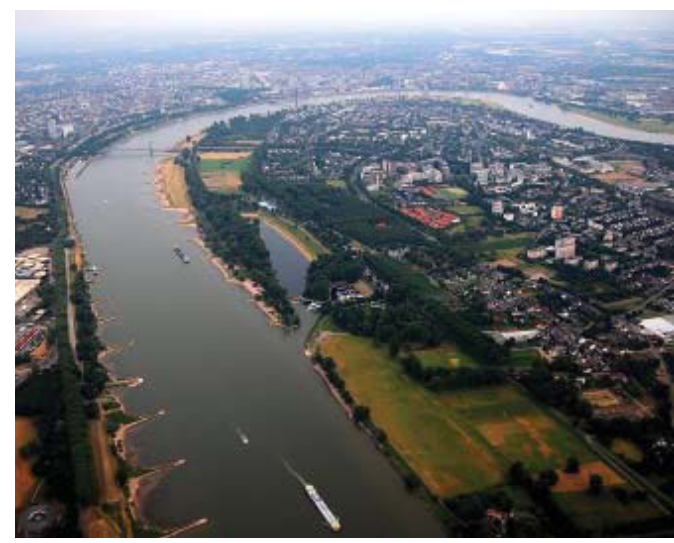

15. RHINE AT DUSSELDORF WIKIPEDIA.ORG, MARCH 2014. 
From the early to mid-20th century, Ruhr became the industrial rustbelt of Europe, with numerous heavy industrial cities lying along its banks, Duisburg being the heaviest industrialized city. (figure 16)

\section{By 1911 the Ruhr was so polluted that it's water was being described by the fisheries association at the time as "yellow soup with foam", "milky grey mud, "oil slick" or "nothing but sewage". (Fullagar et. al, 2012, p.92)}

The Ruhr is now a much cleaner river, thanks to a combination of stricter environmental controls, a transition from heavy industry to light industry, and cleanup measures, including the reforestation of slag and brown fields. The Rhine has also improved drastically in recent years, following the decisions of Rhine Ministers to pass the first environmental protection conventions. Since these were implemented, water testing has indicated that the water quality has been improving every year. Optimists suggest that, "it may even be possible to restore the river to [a] living space inside and outside its channel, with a diverse food plain and corridor, and with animals and plants thriving amid the coalfields, chemical factories, hydro dams, and cities." (Mann, 1973, p.201) Regardless of the improvements that have been made, by the time the Rhine reaches the Netherlands, the water is still heavily polluted. (Mann, 1973, p.156)

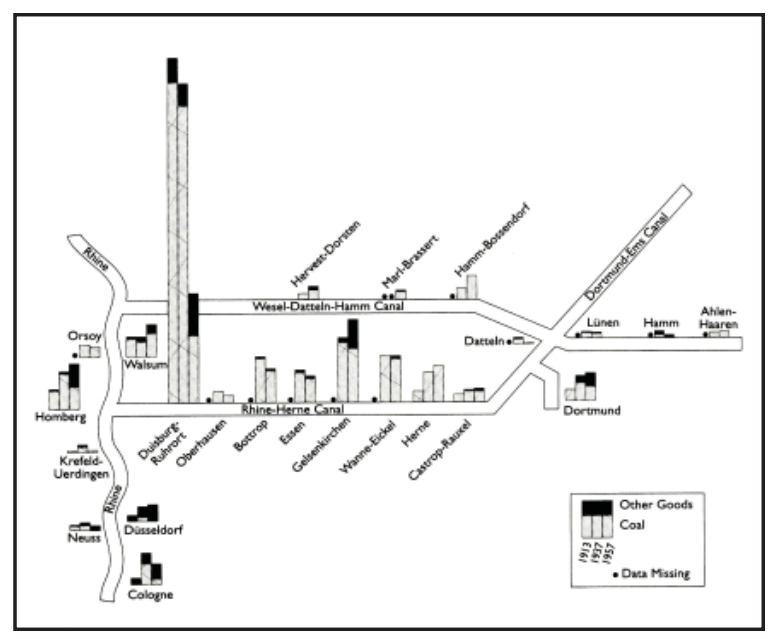

16. INDUSTRIES ON RUHR, CIOC 1, NOV 2013. 

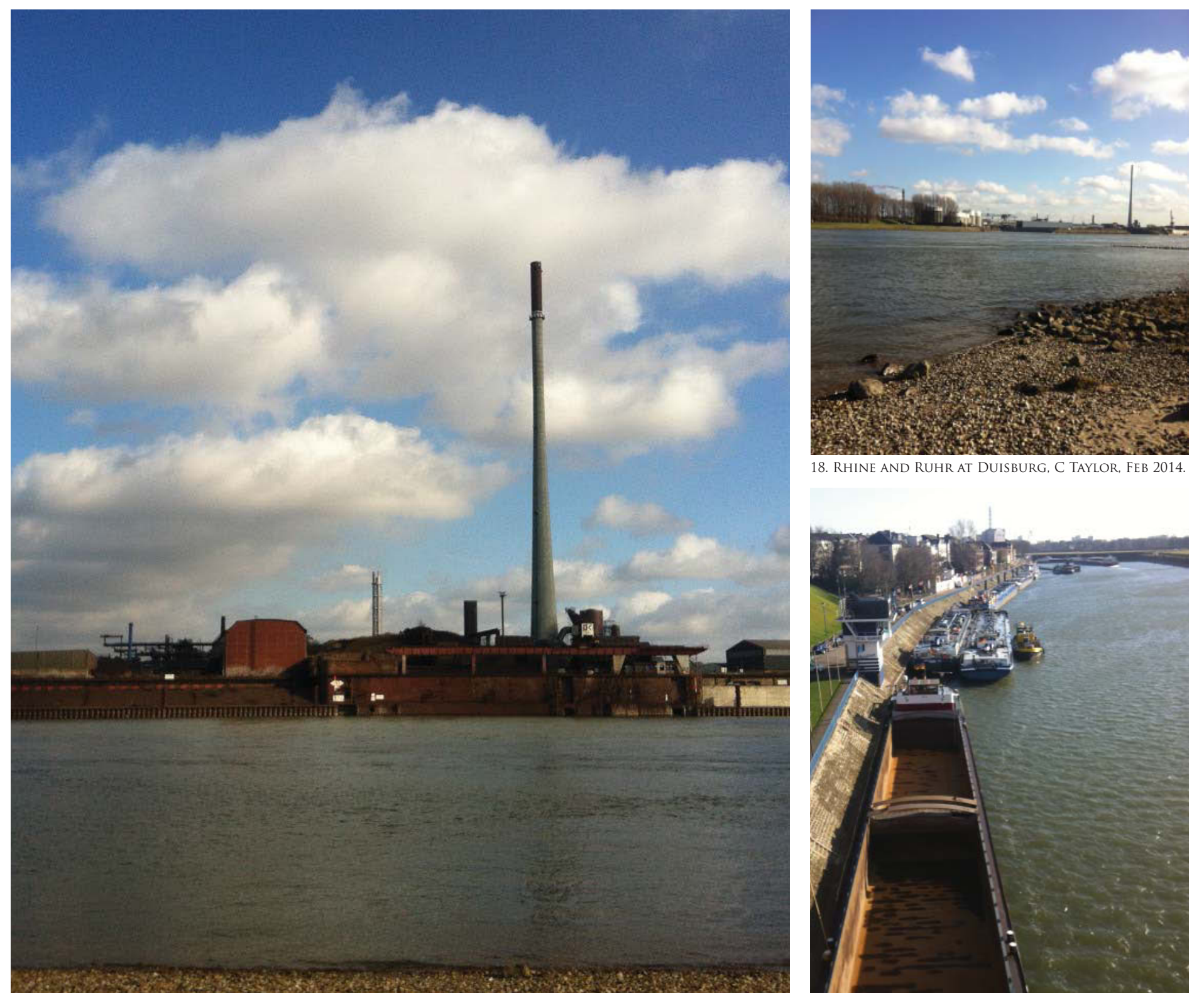

18. RHINE AND RUHr AT DUISBURG, C TAYLOR, FeB 2014

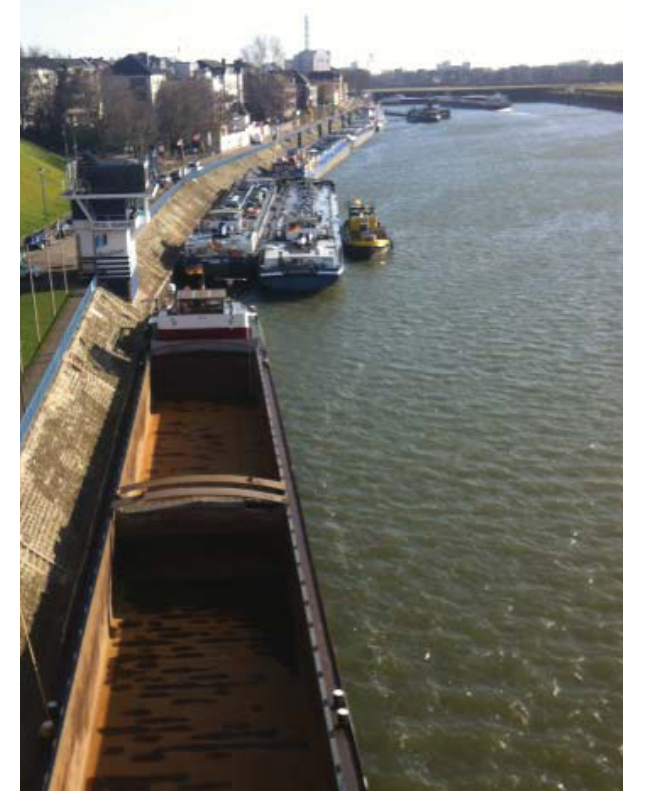

19. Abandoned barge on RuHr, C TAYLOR, Feb 2014 


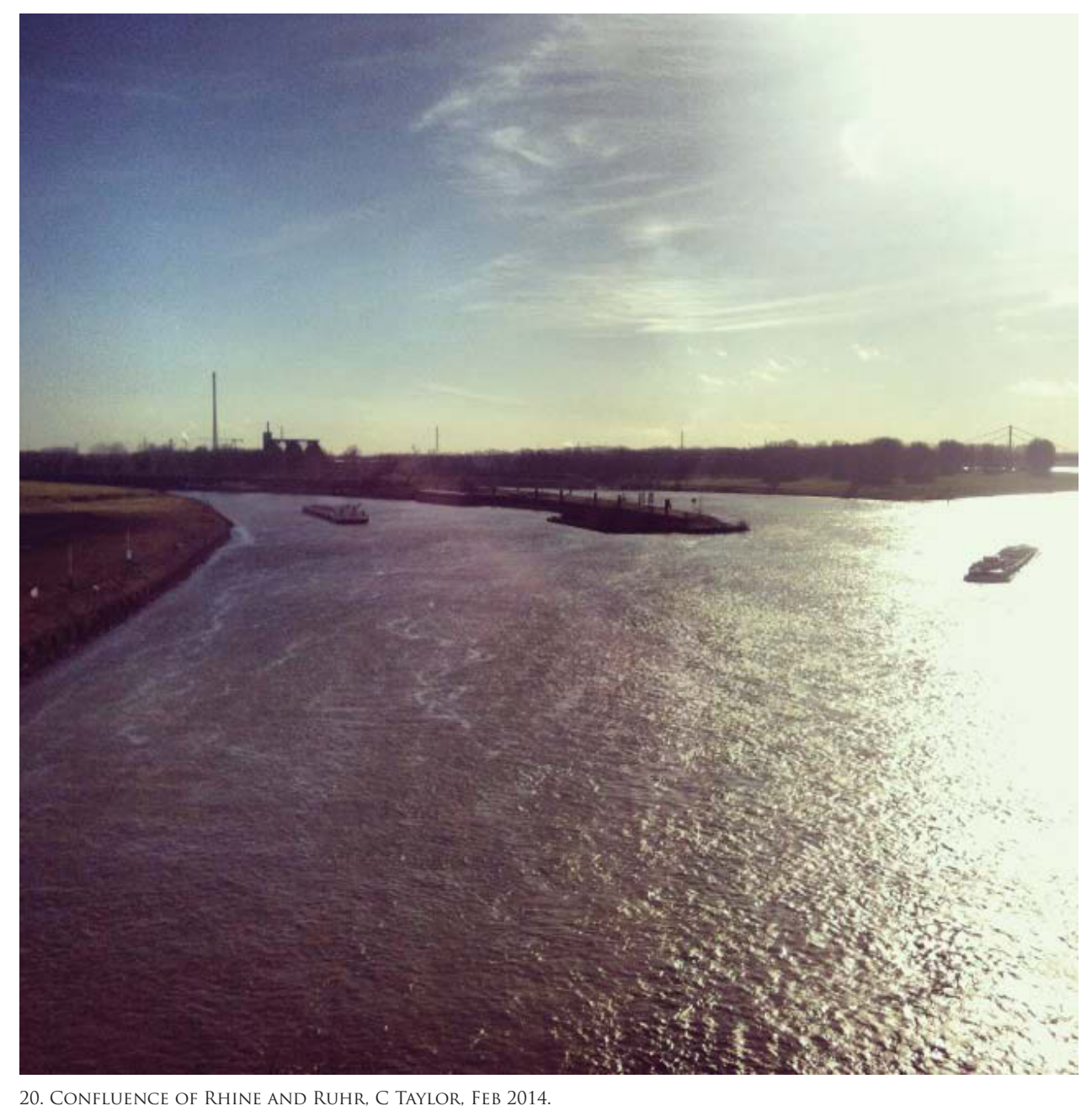




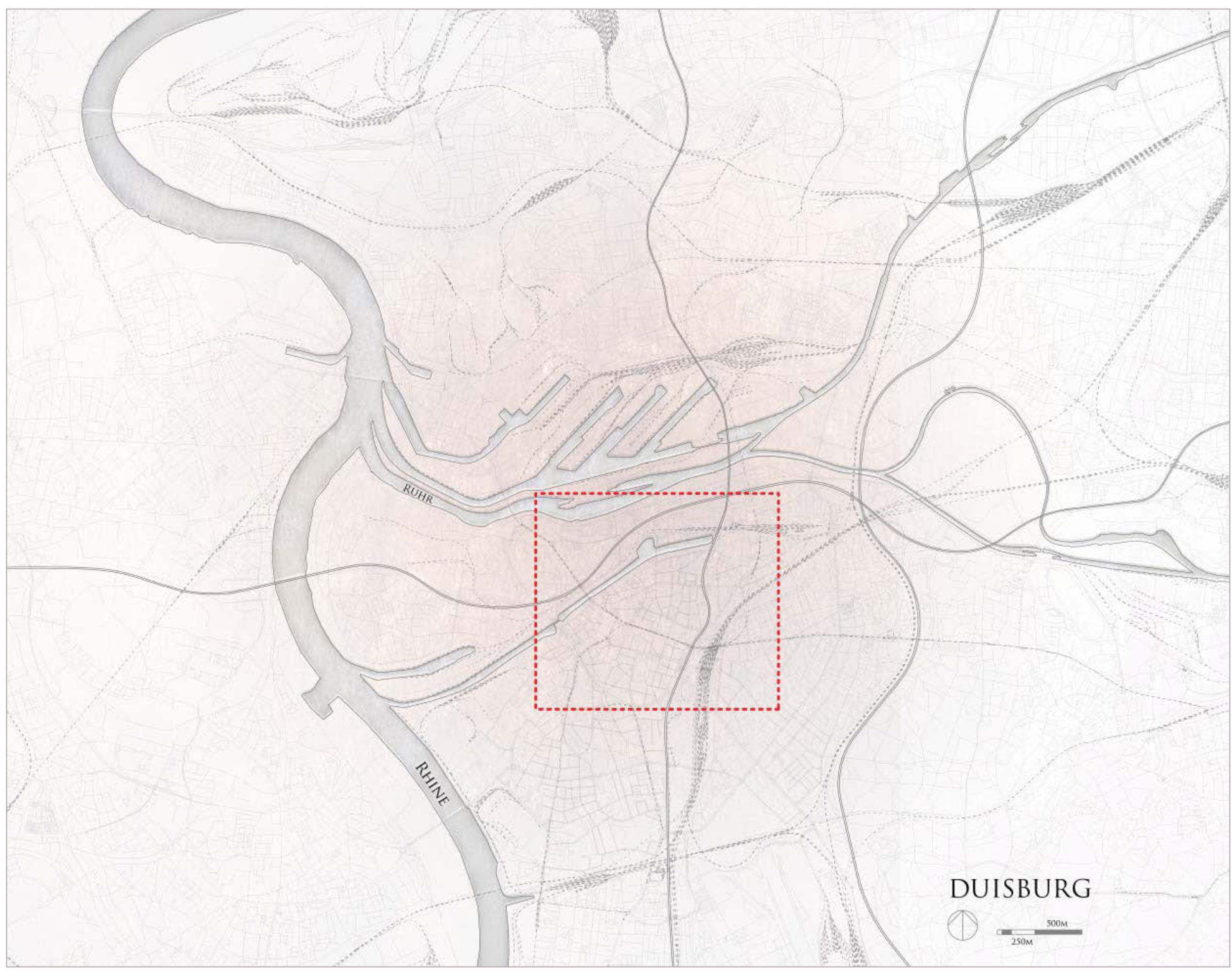

21. THE RUHR, RHINE AND DUISBURG - SITE PLAN, C TAYLOR, MARCH 2014 


\section{DUISBURG}

Duisburg is a city steeped in its industrial past. Located at the confluence of the Rhine and Ruhr Rivers, Duisburg marks the beginning of a steel belt that continues on until Dortmund; "the regional fabric is one of tightly clustered, heavy clouds of smoke and steam have been the classical sky-scape above the blast furnaces and mining shafts of the Ruhr." (Mann, 1973, p.141)

Today's Duisburg is a result of numerous incorporations of surrounding towns and cities. It is the fifteenth-largest city in Germany and the fifth-largest city in North Rhine-Westphalia, with 488,218 residents as of the end of 2010. With the world's biggest inland harbor (Duisport) and its proximity to Düsseldorf International Airport, Duisburg has become an important venue for commerce and is renowned for steel production. As of 2000, $49 \%$ of all hot metal and $34.4 \%$ of all pig-iron in Germany was produced there. (Kalinoski, 2011, p.4) While the last remaining coal mine closed down in the summer of 2009, and no coal products are produced in Duisburg anymore, it is still a thriving centre of trade.

At Duisport, large sea faring ships transfer goods onto smaller boats that travel up the Ruhr and vice versa. It is in this transfer and trading of cargo that the city now makes its money.

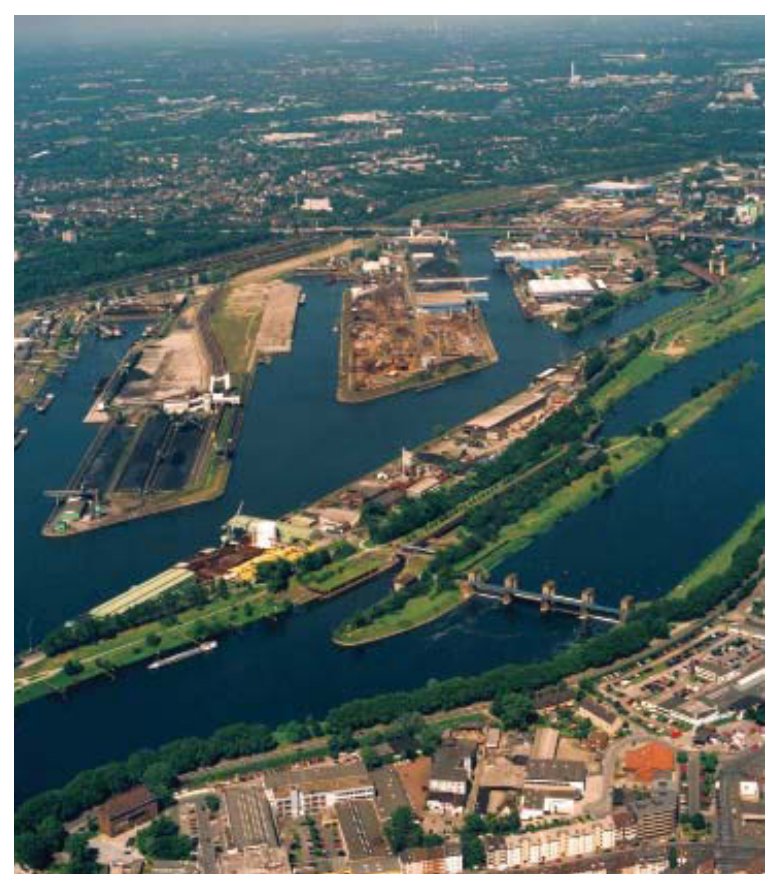

22. DUISPORT AND RUHR htTP://WWW.PORTSTRATEGY.COM, FEB 2014.

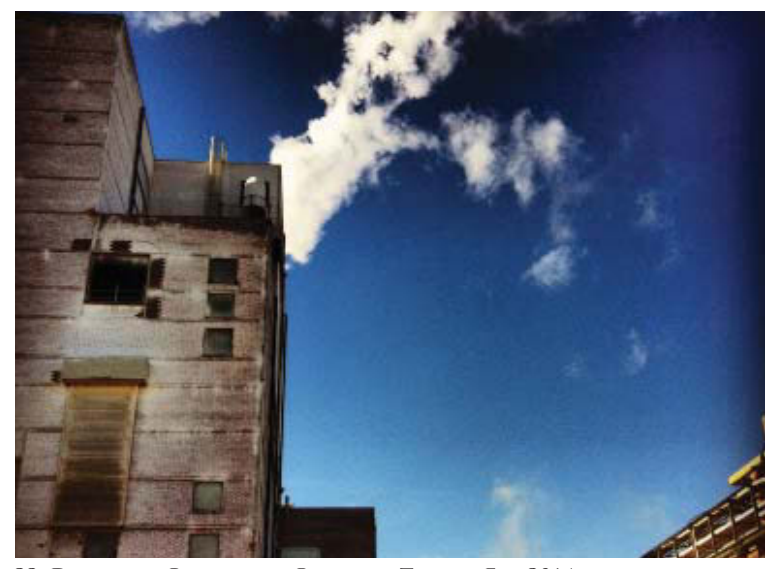

23. Duisburg ReCyCling Plant, C. TAYLOR Feb 2014. 


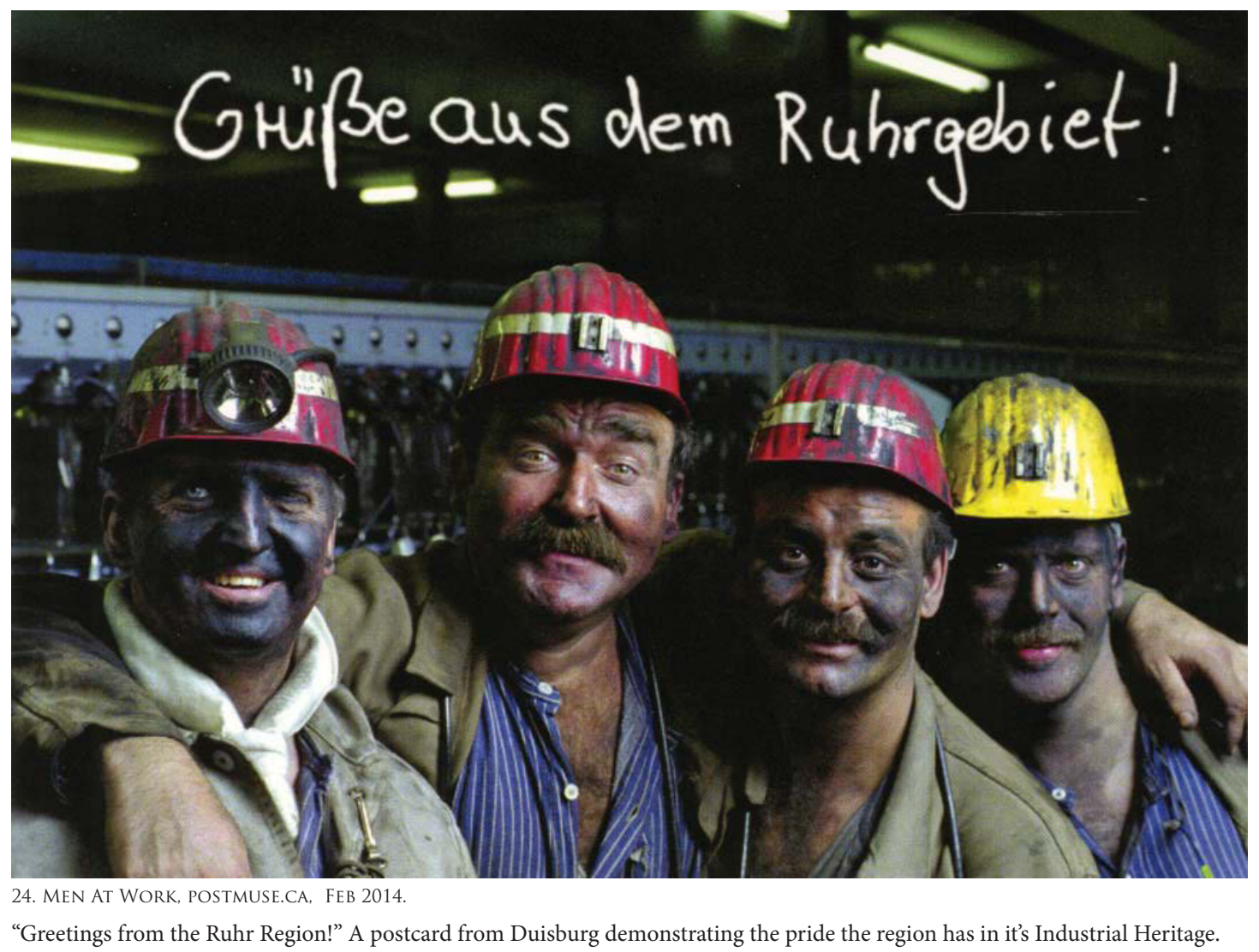




$$
\pi
$$




\section{INNENHAFEN, HOLZHAFEN}

Duisburg's Innenhafen (Inner Harbour) encompasses an area of 89 hectares and is approximately 4 kilometers in length. Bounded by important pedestrian pathways, the Inner Harbour is the closest waterway to downtown Duisburg, making it an ideal location to propose a tourist port development. Populated by former industrial buildings that are now being converted into restaurants and museums, the Inner Harbour is one of the main tourist attractions in the Rhine region. (figure 26)

With a rich history, Duisburg's Inner Harbour dates back to the mid-19th century. 1000 years ago, the Rhine shifted significantly westward, leaving Duisburg connected to the Rhine by only a dead arm. This shift caused trade to decline significantly and continued to do so until the 19th century when the Duisburg Inner Harbour was created, re-establish trade and Duisburg as a major hub for industry. Initially the Inner Harbour was used primarily for the timber industry, which supplied timber to the mining industry that was already established on the Ruhr River. Gradually grain mills, as well as storage warehouses began to populate the banks of the Inner Harbour. At the height of the industrial revolution, the Inner Harbour was the primary point of trade and commerce in the Ruhr region. During the mid-20th century the grain mills began to decline, leaving the inner harbour with countless abandoned industrial buildings. The waterway also became abandoned and rendered the harbour economically insignificant.

As part of an initiative by the city to rejuvenate Duisburg and the

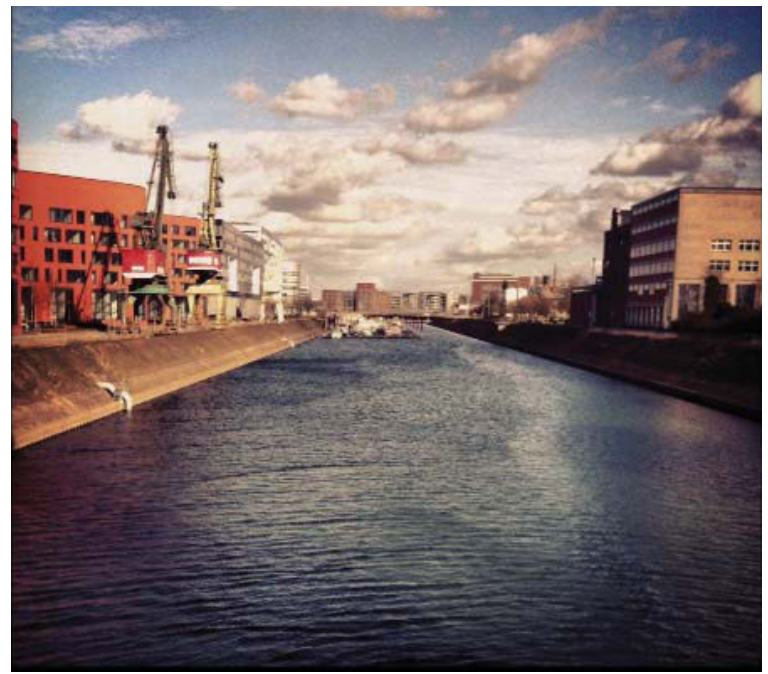

26. DUisburg InNer harbour, C. TAYlor, Feb 2014. 


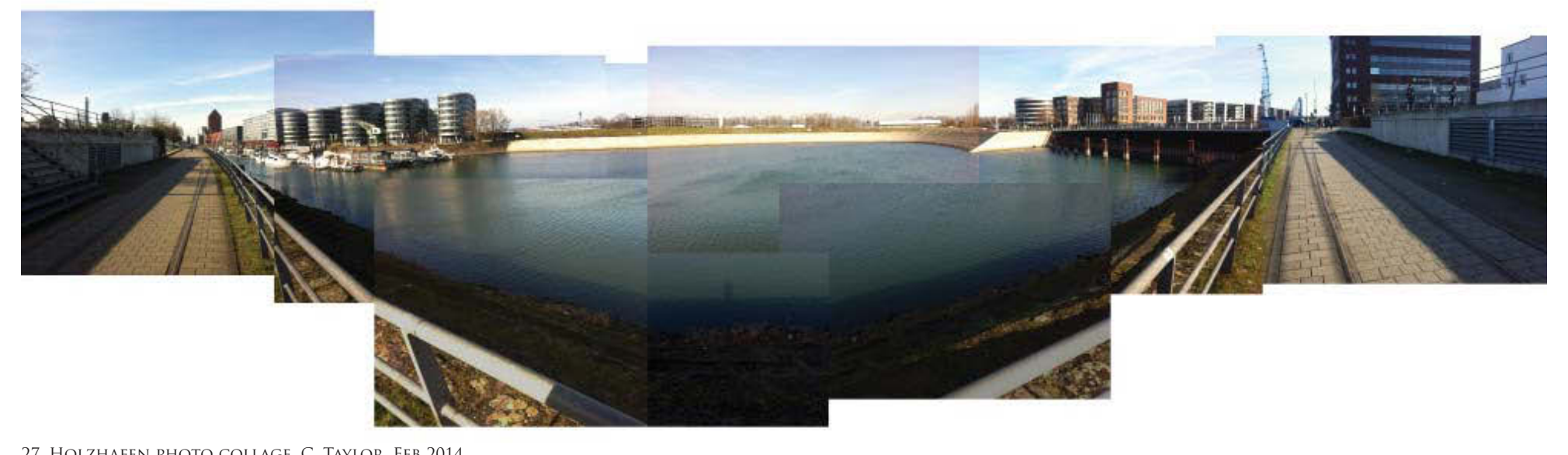

27. Holzhafen photo collage. C. Taylor, Feb 2014 
Ruhr region once the steel and coal industries began to decline, a design for the transformation of the entire Inner Harbour was implimented as part of the International Building Exhibition Emscher Park. The International Building Exhibition Emscher Park, begun in 1983, was a ten year program intended to address the future of the North Rhine-Westphalia region. It included 17 municipalities in the Ruhr region, produced approximately 120 projects consisting of industrial monuments, housing and urban development projects, creation of parks and recreational areas, as well as social initiatives. Over the course of ten years, approximately 5 billion dollars were invested into this initiative. In 1991, an international competition was held to establish a master plan for the Inner Harbour, aimed to draw life to the waterfront and to help revitalize Duisburg. British architect, Norman Foster won the competition and was appointed the head architect by Duisburg's City Council (figure 28 for Foster's site plan proposal). Foster's guiding principle for the project was to create a flexible framework that allowed different elements to be developed independently over time by various architects.

\begin{abstract}
The practice's work in Duisburg demonstrates that the trend towards a clean, quiet industries has the potential to reinvigorate declining urban areas and create sustainable communities for the future, where home, workplace and recreation are all close by. In the place of the zoned and functionally segregated city of the twentieth century, it offers a twenty-first century urban paradigm of mixed-use. With many cafes and restaurants, an art museum, new housing, offices, converted historical buildings and a new park, Duisburg Inner Harbour is becoming a thriving commercial and residential centre in its own right. (Foster, + Partner, 2014)
\end{abstract}

Foster's primary development proposal for the Inner harbour was a development called Eurogate, a ten story, semi-elliptical building, that would serve as multi-functional space, addressing the needs

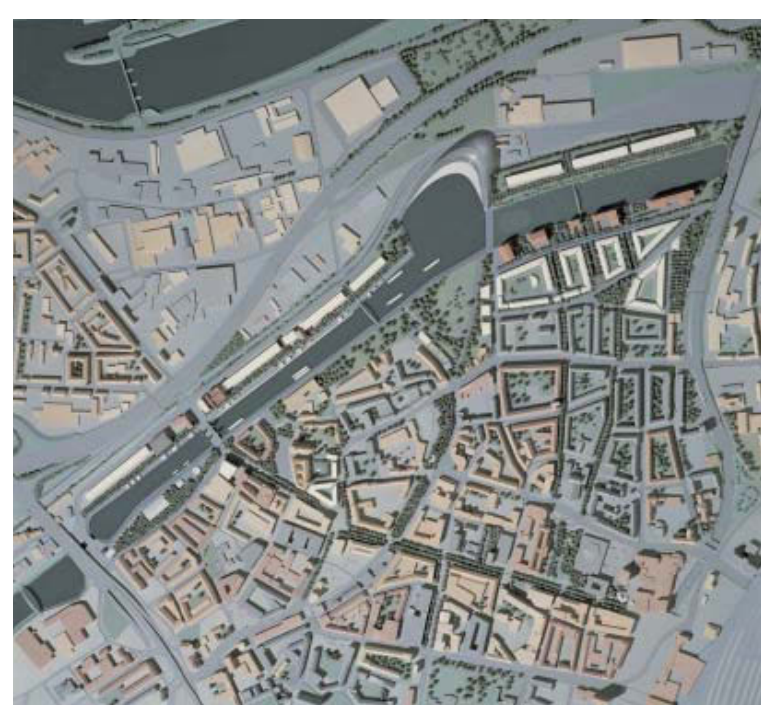

28. Eurogate Site Plan, wwW.Fosterandpartner.com, Feb 2014. 
of the Duisburg community located in Holzhafen. Holzhafen is a large oval area between the marina and the Portsmouth dam in the Inner Harbour that historically was used as a timber port. Today Holzhafen exists as a turnaround area for boats,. It is also located on a stretch of waterway that is a very popular area for fishing.

Eurogate is an estimated 80 million euro proposal that includes $20,000 \mathrm{~m}^{2}$ floor space for offices, $9,000 \mathrm{~m}^{2}$ hotel space offering 150 rooms, as well as conference rooms $\left(1,500 \mathrm{~m}^{2}\right)$, retail \& restaurant space $\left(5,000 \mathrm{~m}^{2}\right)$ and a car park with 720 parking spaces. Eurogate would also include a $7,500 \mathrm{~m}^{2}$ photovoltaic surface that would utilize the harbor water as cold and heat storage and would be approximately $40 \%$ more energy efficient than a typical building. (figure 30 and 31 for the Eurogate building plan and elevation) Foster promotes Holzhafen as the ideal location for development in Duisburg and boasts that the Eurogate is a key element to the successful revitalization of Inner Harbour waterfront.

\begin{abstract}
A crescent shaped building, the volume is punctuated with courtyards and atria to ensure natural ventilation, maximum daylight penetration and views to the water. Within the advanced geometry of the shell, rational rectangular floor plates enable fast and cost-effective construction. Striving to be zero-emission, the building has an ideal south facing orientation, and extensive use of photovoltaic technology gives Eurogate its distinctive façade while generating income from electricity to power up to 200 family homes. At ground level, there will be cafes, a promenade and steps abutting the water, while the configuration of offices inside remains a working brief that can be tailored to suit specific tenants. (Foster, + Partner, 2014)
\end{abstract}

Land development for Eurogate began in October 2007. The construction of promenade steps was completed in 2008 but further construction of Eurogate has been postponed several

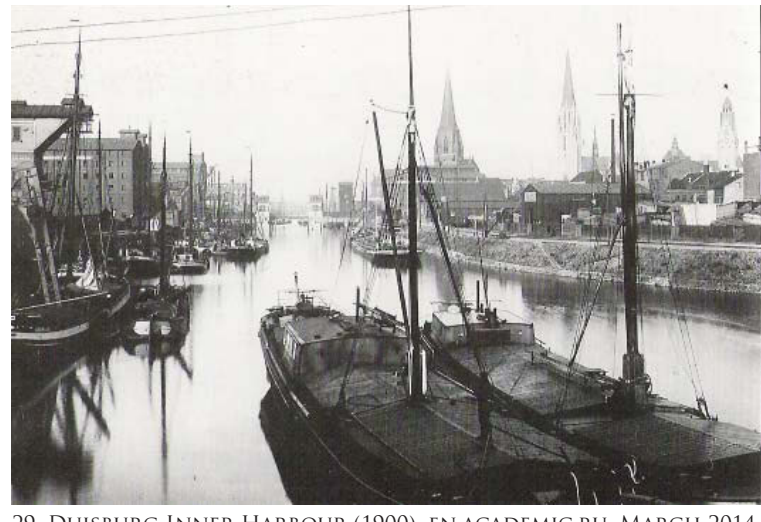

29. DUisburg InNer HARbour (1900), EN.ACADEMIC.RU, MARCH 2014 


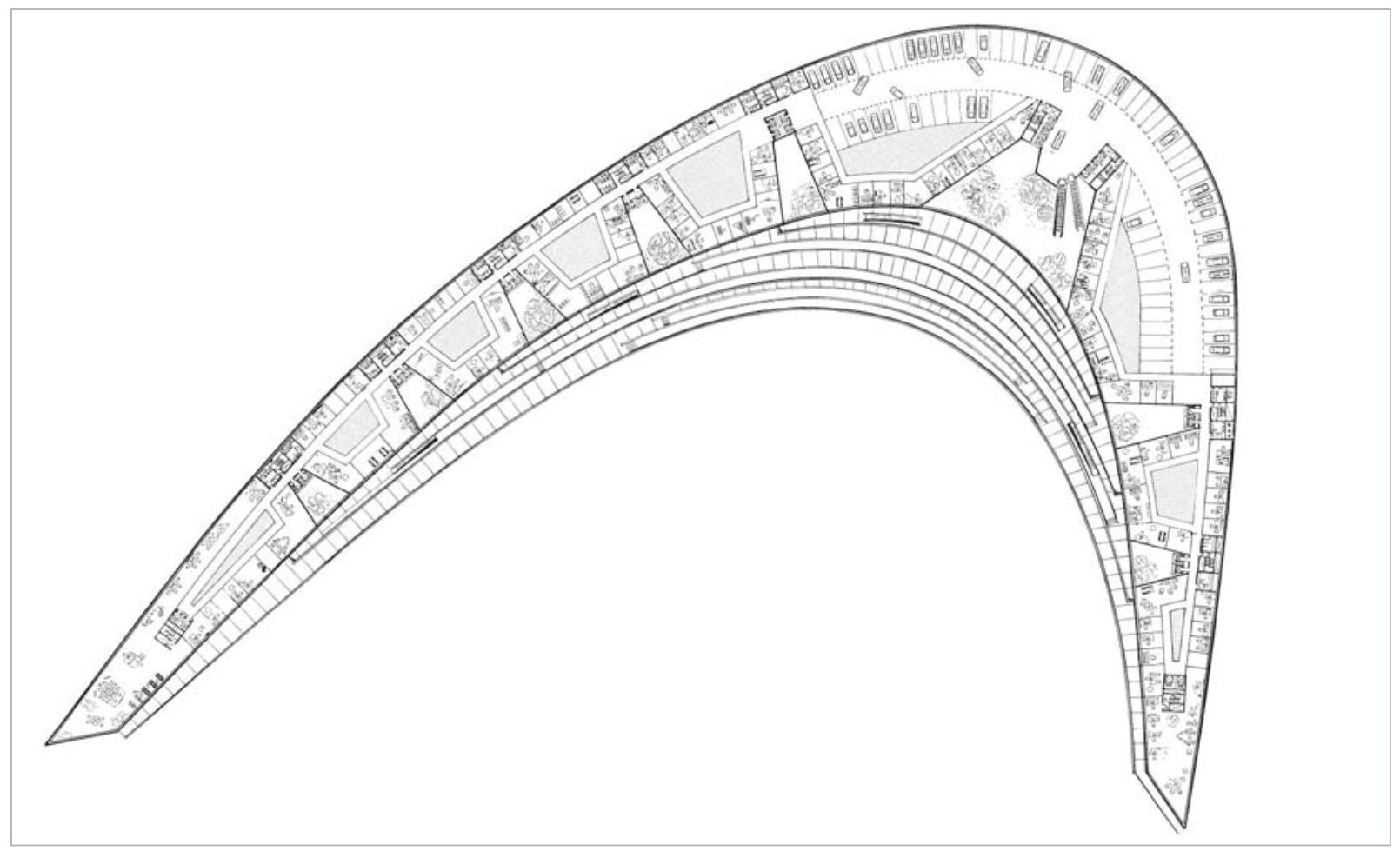

30. Eurogate Building Plan, WwW.Fosterandpartner.com, Feb 2014

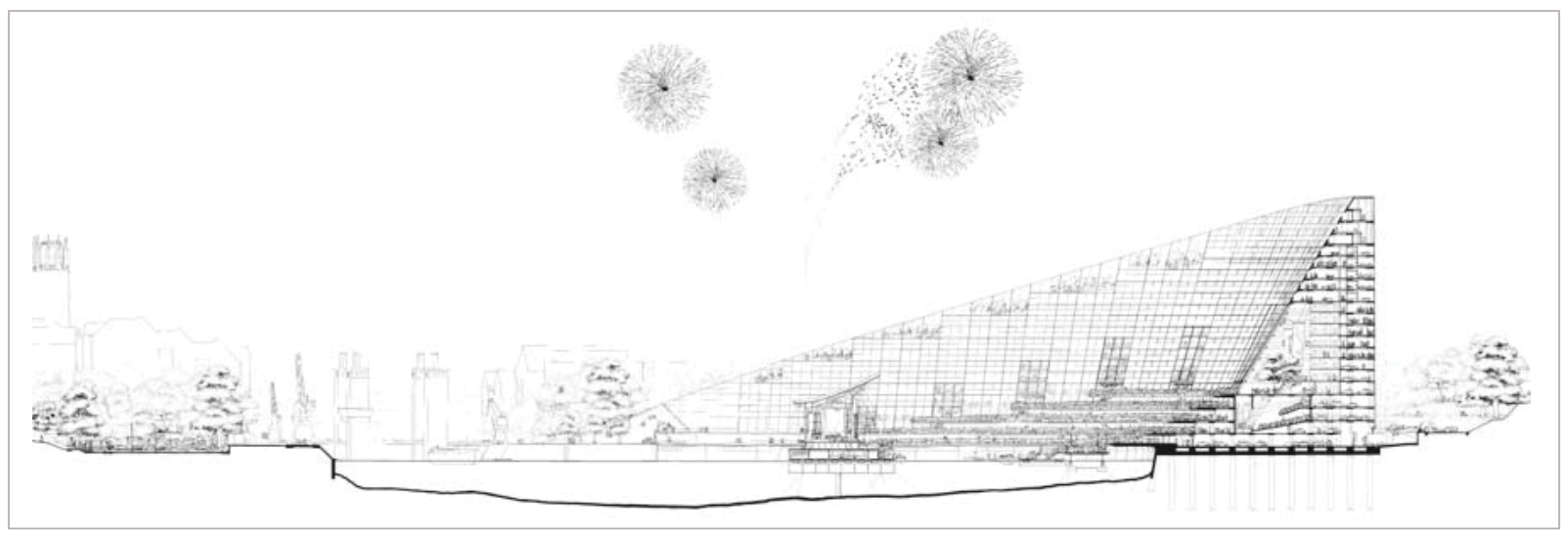

31. Eurogate SeCtion, WWw.FosterandPartner.com, Feb 2014. 
times due to a lack of investors. Thus far, 9 million euros have been spent on site development and the construction of the promenade steps that consists of 574 precast concrete elements (see figures 3234). At this point it appears that the Eurogate development will be postponed indefinitely, leaving the stepped promenade area without purpose and the harbour area inaccessible to pedestrians.

The current (and seemingly permanent) state of this project is a terrible misuse of, arguably, the best site in Duisburg's Inner Harbour. Located directly west of the tourist visitor's centre for Duisburg and directly east of the Inner Harbour Marina, Holzhafen, or the former timber harbour is a prime location for a multi-functional pedestrian space for the people of Duisburg as well as a tourist port. The current blockade around the promenade disrupts the pedestrian movement around the harbour, forcing people to take an alternative route 50 meters out of the way, away from the waterfront. This new promenade begs for pedestrian interaction and engagement at a much smaller, local scale than that of the Eurogate proposal. Holzenhafen is the ideal location to design a public space that all of the residents of Duisburg can enjoy and easily access. Being located well within the harbour, it is a good location for a cruise ship to dock as it allows for the passengers to experience the industrial past on their venture in, and is located within a five minute walk to downtown Duisburg. 

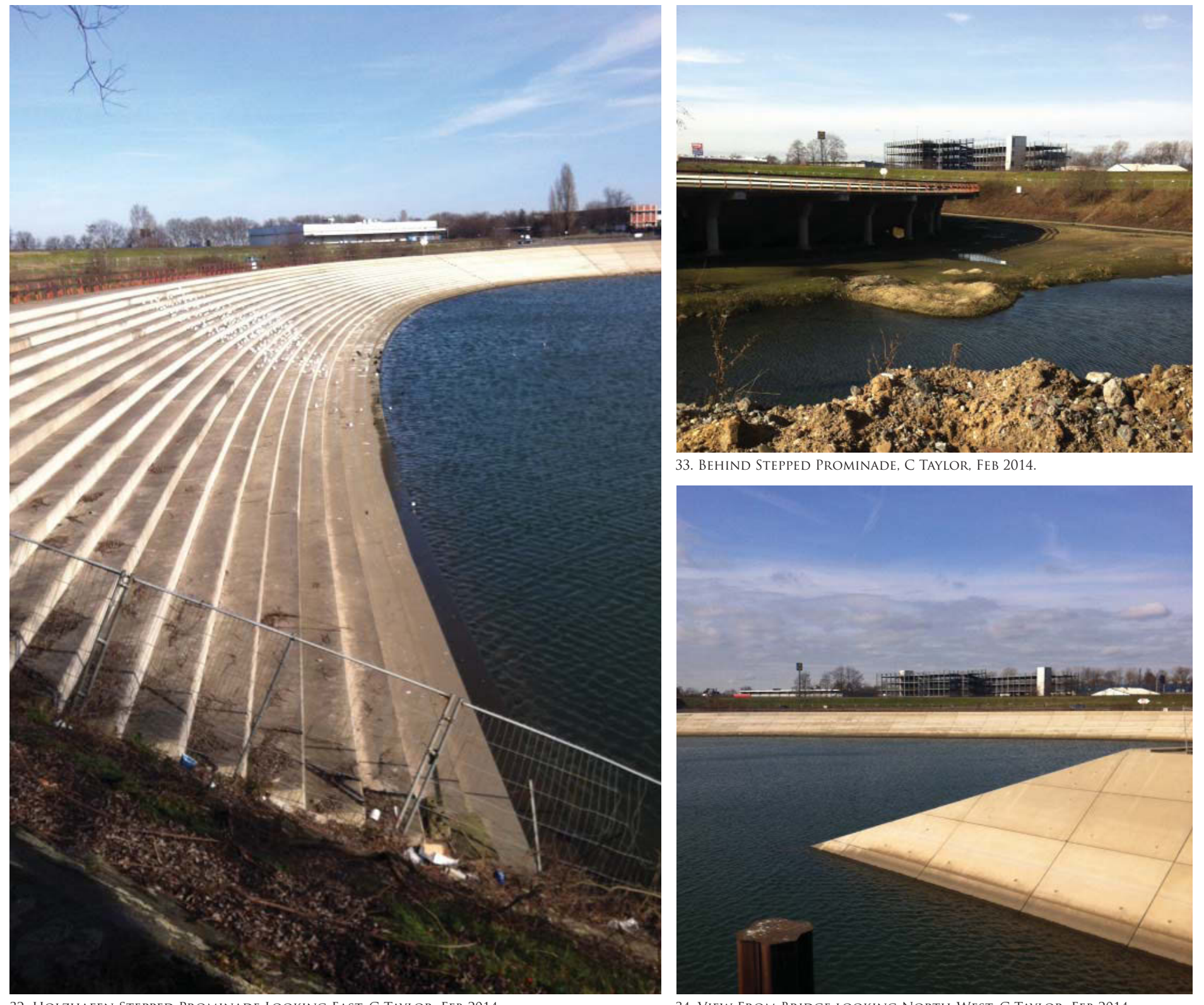

34. View From Bridge LoOking North-West, C TAylor, Feb 2014. 


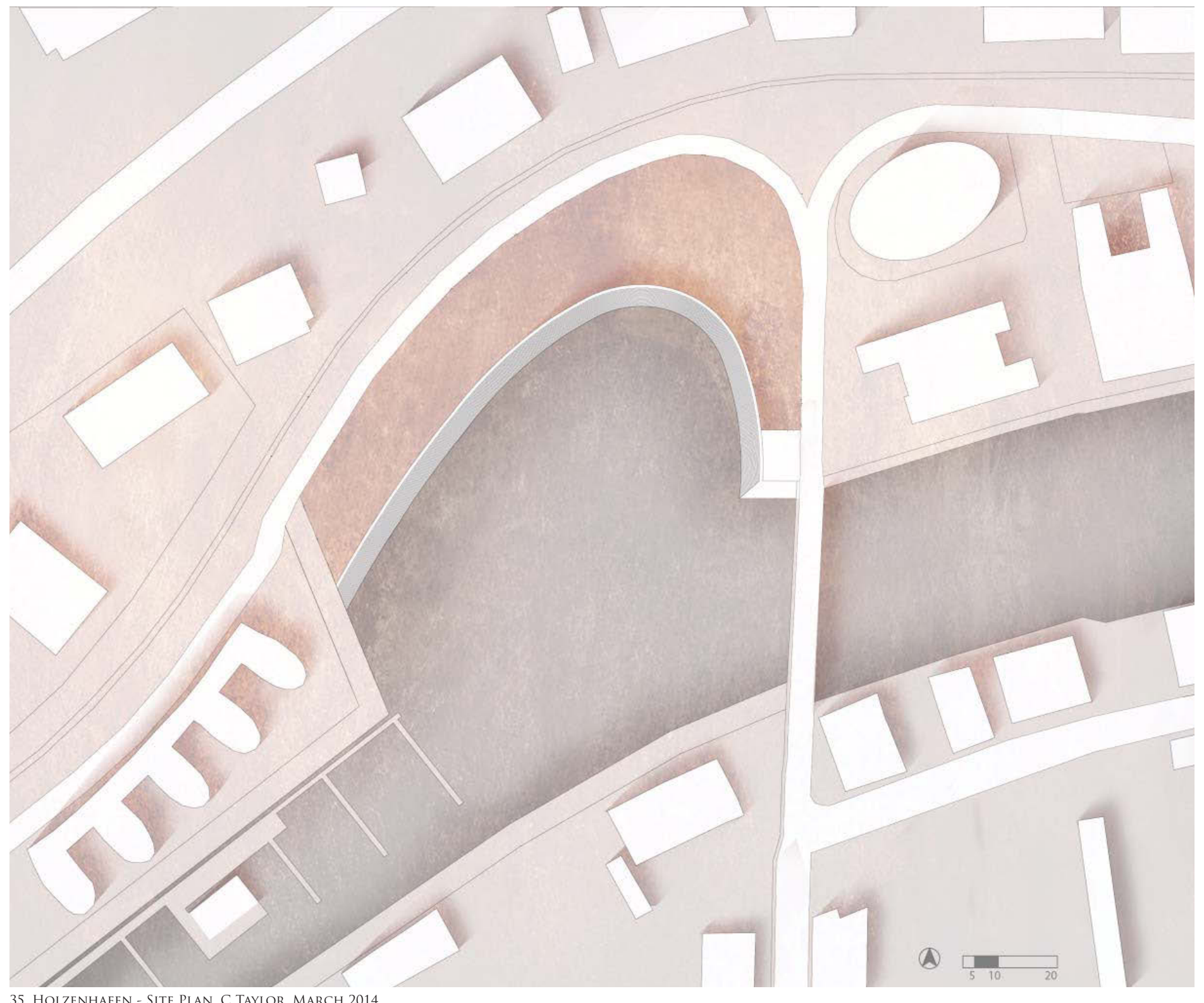




\section{CHAPTER 3 - CASE STUDies}

\section{DUISBURG LANDSCAPE PARK NORTH}

Duisburg along with Dortmond, Essen and Bochum make one of the largest conurbations in Europe today. As Duisburg previously marked the beginning of a steel belt, it now marks the beginning of Germany's Industrial Tourism Trail, which is a $400 \mathrm{~km}$ network of former industrial sites that have been renovated as vibrant tourist attractions along the Ruhr River. As a way of addressing unused industrial buildings and the damage that was done to the environment, these new adaptive reuse projects serve to protect the Rhine from detrimental development while preserving its industrial heritage. The abandoned Norman Foster site is the ideal location for a tourist port as a centre for the numerous adaptive reuse projects located along Germany's Industrial Tourism Trail.

Landscape Park North, located in Duisburg is the most well known and arguably the most successful example of one such project. What originally began as a design competition, developed and grew to become an internationally renowned adaptive reuse project. The initial concept was to integrate, shape, develop, and interlink the existing patterns from their industrial use and to suggest a new interpretation. The initial design criteria also sought to use vegetation to decontaminate the one highly polluted Ironworks site. The end product was a large-scale adaptive reuse project that met and exceeded these design parameters: Duisburg Landscape Park North serves as an exemplary model for what future adaptive reuse products can and should be.

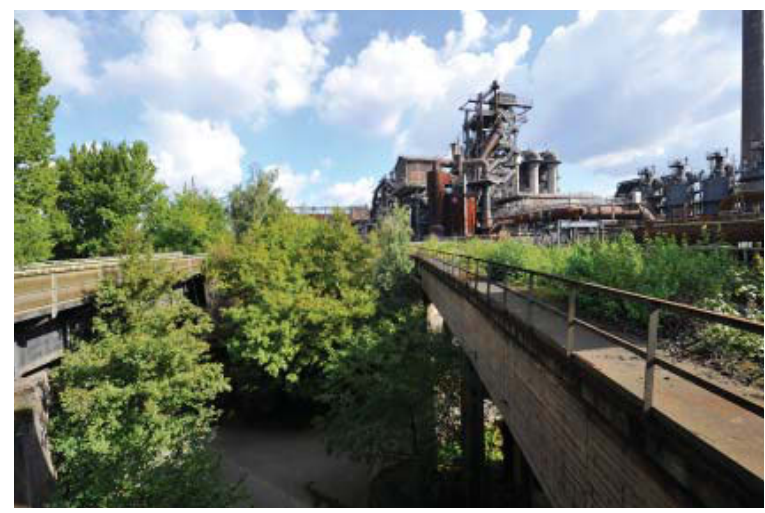

36. LANDSCHAFTSPARK . HTTP://EN.LANDSCHAFTSPARK.DE, NOV 2013 


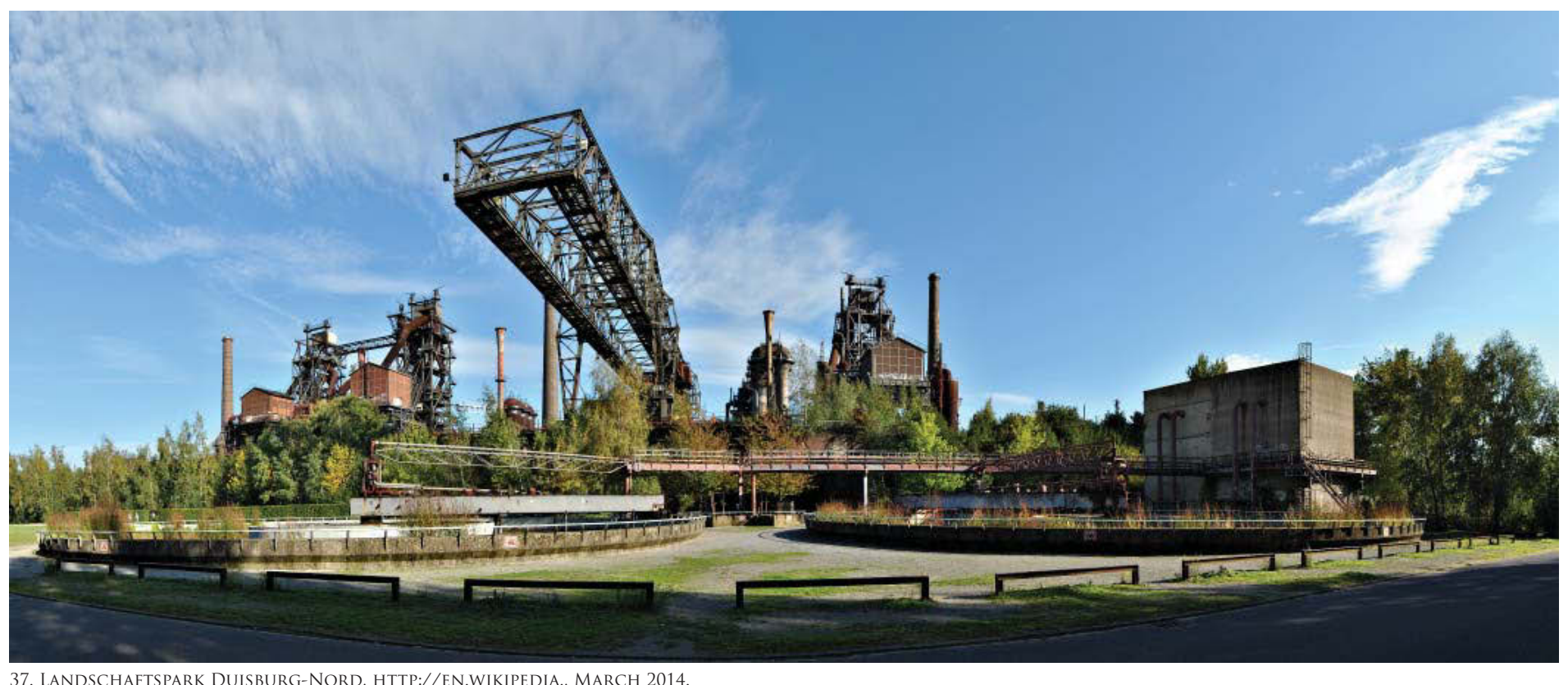

37. LANDSCHAFTSPARK DUISBURG-NORD, HTTP://EN.WIKIPEDIA., MARCH 2014 
The Parklands at the Duisburg Landscape Park North are one of the region's most popular attractions, regardless of season (Kalinoski, 2011, p.9). Here individuals are able to experience Duisburg's unique history while surrounded by lush greenery:

Visitors walk past the blast furnaces and casting houses, the full extent of the former industrial park opens up. Green cycle trails and footpaths on former railway lines, play areas and climbing walls, expanses of water filled with life, areas for the very latest sports. (Landschaftspark Duisburg-Nord, 2010)

Latz and Partners, who won the competition for the redesign in 1991, state that memory was the central concept and imperative in the design. Emphasis was placed on, "the site's current condition and [they] designed it with the idea that a grandfather, who might have worked at the plant, could walk with his grandchildren, explaining what he used to do and what the machinery had been used for" (Kalinoski, 2011, p.12). Previous buildings used to house coal and ore now serve as a garden that is open to the public and is now well on its way towards decontamination (figure 38). Latz and Partners have successfully used both formal and informal vegetation to rehabilitate and quickly transform a once brownfield site into a hospitable environment.

The Gasometer, which was built in 1920 and originally used as a storage tank for blast furnace gas (a bi-product of the smelting process), has been ingeniously reused as a scuba diving school. In adapting this existing structure, divers can learn and discover a truly unique underwater landscape (figures 39 and 40). This artificial landscape provides the opportunity to explore a shipwreck, an aircraft wreck, two cars, an artificial reef, and other objects, while experiencing night time diving conditions rarely
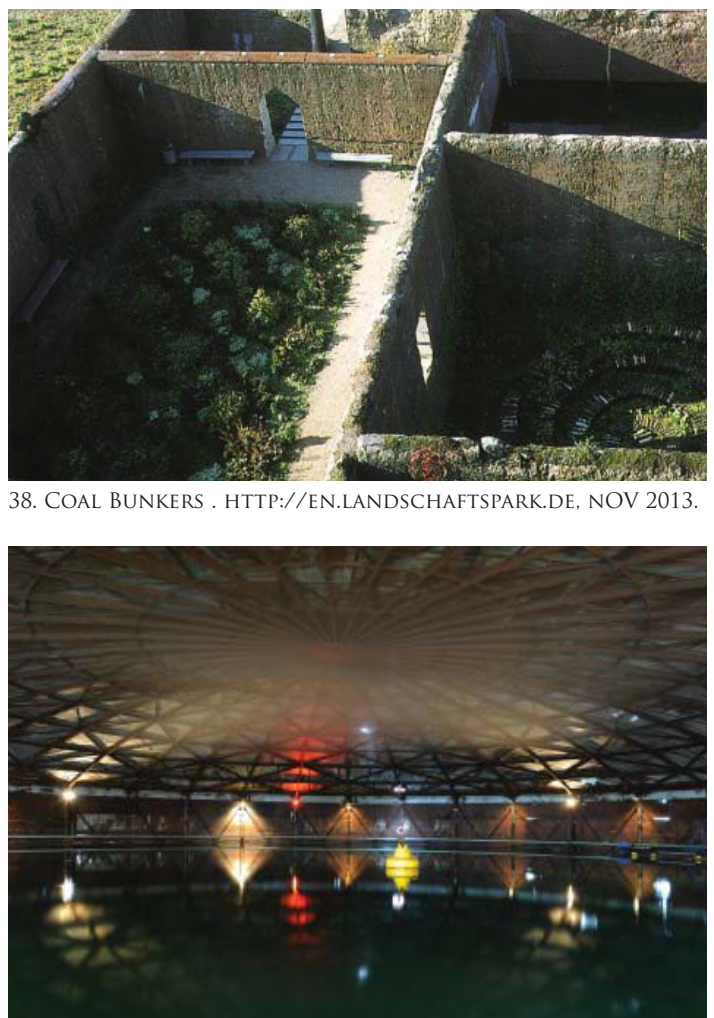

39. GASOMETER . HTTP://EN.LANDSCHAFTSPARK.DE, NOV 2013.

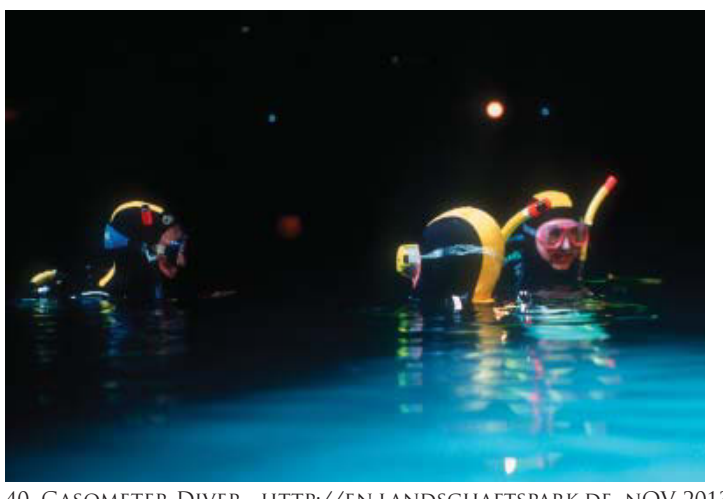

40. GASOMETER DiVER . HTTP://EN.LANDSChAFTSPARK.DE, NOV 2013. 


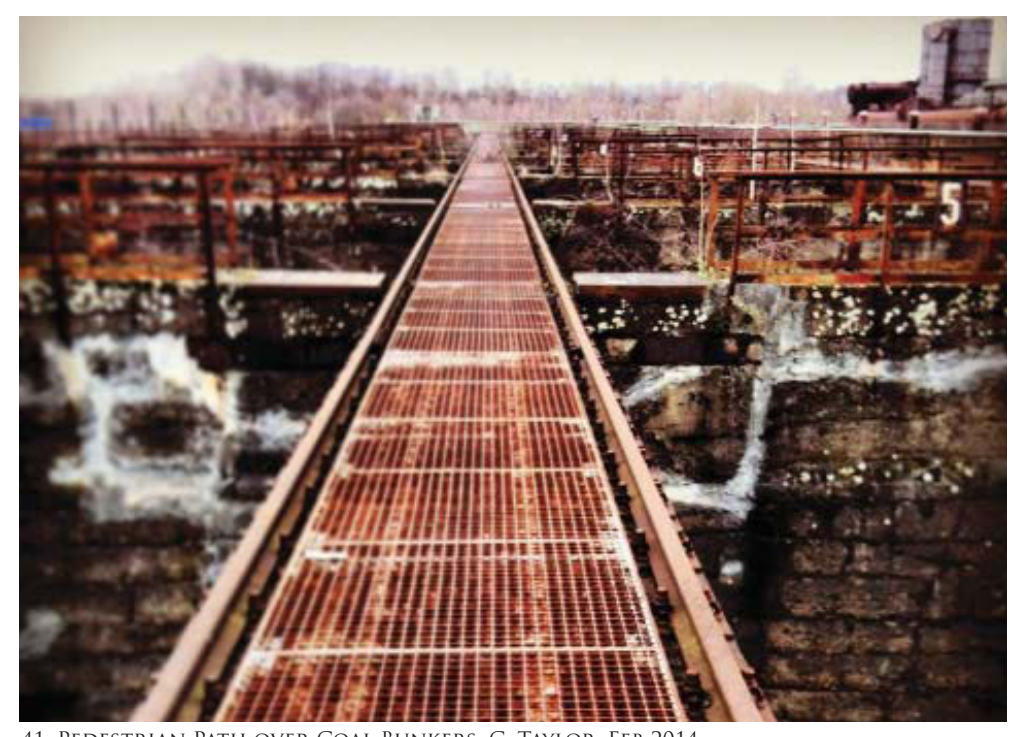


available for scuba schools (Kalinoski 2011, p.9).

The key to a successful adaptive reuse project is allowing a user to experience an existing structure in an entirely different context and use than its original design, without neglecting its past or previous programming. The Gasometer diving school is one such example of how the public can experience Duisburg's industrial heritage in an original and functional way.

Jonathan Park's light installation (in association with Fisher Park Design) is the highlight of the Duisburg Landscape Park North. Jonathan Park and Fisher Park Design have previously choreographed the lighting for numerous major performing artist concerts, including Tina Turner, Pink Floyd, U2, and the Rolling Stones, to name a few. The iron works factory is their first permanent installation. For 6-7 hours every night throughout the year, the ironworks factory is lit up in countless energy-saving LED lights. Visitors are also able to explore the ironworks exterior while experiencing a sea of ever-changing colours (figure 42). The experience of discovering the Ironworks factory lit up with this light installation has been called breathtaking and awe-inspiring by visitors and is quickly putting Duisburg on the map as a major tourist destination.

The aforementioned projects in Duisburg Landscape Park North are just a few of the reuse projects that exist on site. The former blasting hall has been converted into a 700 seat theatre, the central power plant has been converted to a very successful performance venue, which is hired out for events, and the former office building

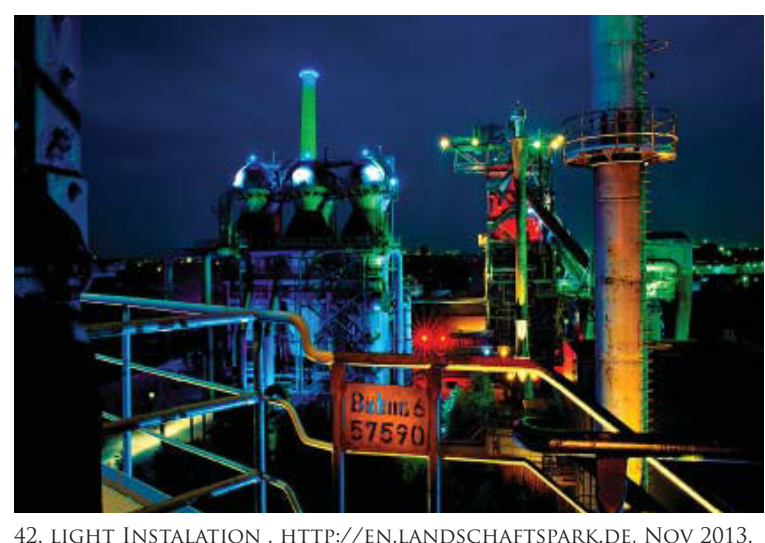

42. LIGHT INSTALATION . HTTP://EN.LANDSCHAFTSPARK.DE, NOV 2013. 
of the iron works facility has been transformed into a hostel to support the rapid influx of tourists to the area (Kalinoski 2011, p.8).

There are numerous additional adaptive reuse and redesign projects in the Ruhr region, taking advantage of the abundance of abandoned, unused industrial buildings that still exist. These projects have made Duisburg renowned for innovative adaptive reuse designs and have made Duisburg an emerging international tourist destination. There is now a determination to protect the Rhine and the Ruhr from detrimental development while emphasis and focus is placed on preserving its industrial heritage. 


\section{LIVING MACHINE}

A Living Machine is a patent trademark for a form of ecological wastewater treatment that is designed to mimic the cleansing functions of wetlands. This waste management technique is a bioremediation system that involves the use of hundreds of organisms such as snails, plankton, bacteria, algae, fish and plants to accelerate the water cleansing process. There are numerous advantages of living machines over conventional wastewater treatment systems. Traditional treatment utilizes harmful chemicals to treat the effluent, and often produces a toxic byproduct that is usually incinerated, which in turn creates air pollution. This sludge by-product is highly toxic and usually mismanaged, as Smith explains:

Traditional processes do not adequately sequester heavy metals, and the sludge can also contain manmade organic compounds that are extremely difficult to break down. Some critics assert that the disposal of this sludge is not responsibly overseen in the United States, so the excess sludge is sometimes spread on public forest or even agricultural land, dumped in landfills or the ocean, and sometimes incinerated (Smith, 2008, p.23)

Living Machines produce beneficial by-products, such as plant products as well as pure heavy metals that, although highly toxic, can be moved off site and properly recycled in a way that would not be at the environment's expense.

Living machines are typically located in temperate or tropical climates. However, Professor Hollebone's proposal for a living machine at Carleton University employs a system of tanks housed in a greenhouse to prevent freezing in the winter. In addition to preventing freezing, the placement of some of the tanks in a

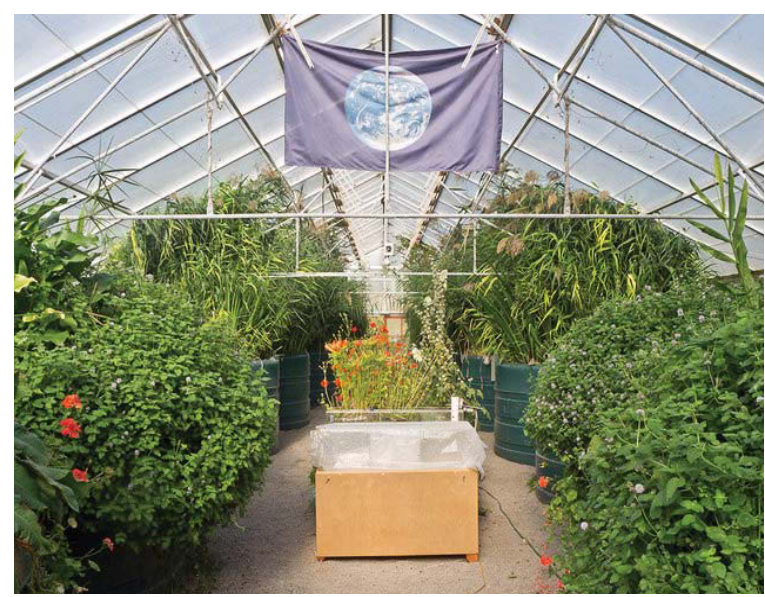

43. INTERIOR OF FINDHORN LIVING MACHINE. HTTP://WWW.GEOGRAPH.ORG.UK/. FEB 2014 
greenhouse raises the rate of biological activity as well as increases the speed at which the living machine functions. Duisburg has a climate that is similar to Ottawa, with somewhat milder winters, thus Professor Hollebone's extensive research on creating a Living Machine in a northern climate serves as a good example of how the living machine could be incorporated into in the design of the port and how it would perform.

Professor Hollebone's proposal for a Living Machine at Carleton University spans just over 2 acres, roughly the size of a football field (figure 44). It was created to handle the wastewater of the entire population of Carleton University, of approximately twenty thousand people. It requires a minimum population of two thousand people to maintain and would require five full-time biologists to oversee the system. In this design, the effluent makes its way through five different processes starting in the solar tanks and gradually making its way to the marshes.

Although Living Machines vary in terms of specific processes and stages of water treatment, they are typically comprised of six stages:

Stage 1: Anaerobic Reactor.

The initial stage of the Living Machine, the Anaerobic reactor, is similar in appearance to a septic tank and is usually buried underground beside the anaerobic septic tank where the sewage is initially collected and stored. "The main purpose of the anaerobic reactor is to reduce the concentrations of BOD5 (biochemical

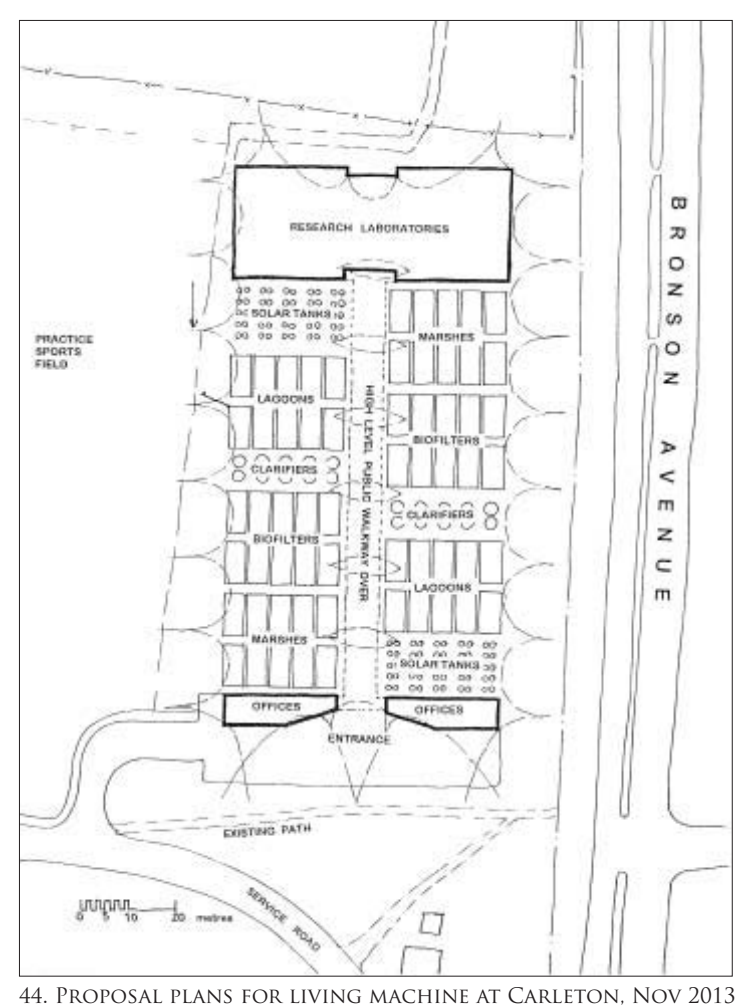

44. Proposal PLANS For LIVING MACHINE AT CARLETON, NOV 2013 


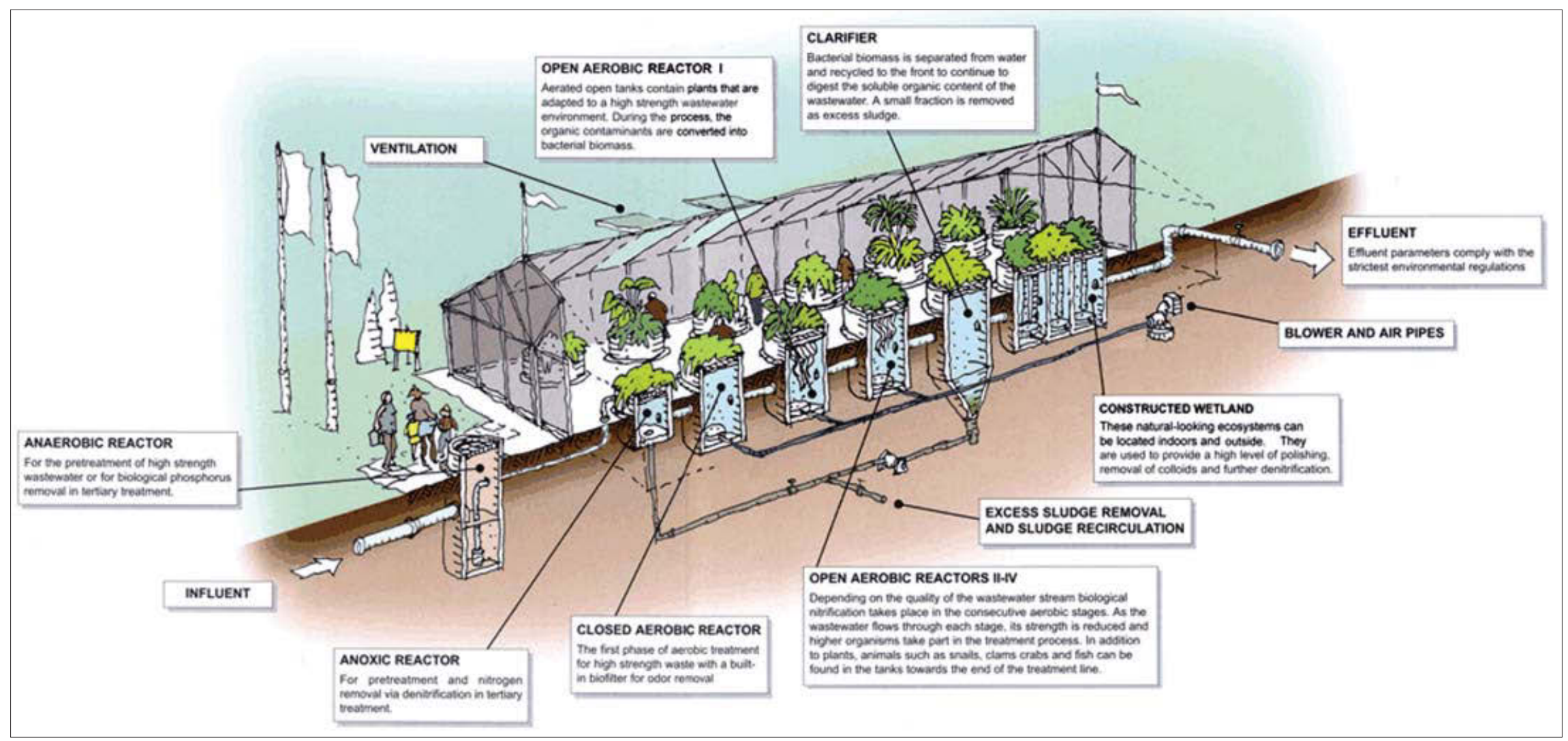

45. SCHEMATIC DIAGRAM OF THE STAGES OF THE FINDHORN LIVING MACHINE, HTTP://WWW.THEECOLOGIST.ORG/ MARCH 2014 
oxygen demand) and solids in the wastewater prior to treatment by the other components of the process." (United States Environmental Protection Agency, 2) In this initial stage, solids and toxins are broken down. Additionally, some Living Machines contain a carbon filter for odor control.

\section{Stages 2-4 Tidal Cells}

After being treated by the Anaerobic reactor, the water is now classified as grey water (no longer black water) and stages 2-4 are hosted in a Green House. It is at this stage that River water can be introduced for cleansing and to help with the flow consistency of the system. While commonly referred to as tidal cell beds, the specific stages are referred to as Step 2: Anoxic Reactor, Step 3: Closed Reactor and Step 4: Open Aerobic Reactors. The design of these beds, as well as size and number are determined by the characteristics of the influent characteristics, which vary considerably based on the site. The purpose of these beds is to reduce $\mathrm{BOD} 5$ to better than secondary levels and to complete the process of nitrification.

Stage 5: Clarifier

An additional settling tank is housed in the greenhouse before the influent is passed to the final stages of the living machine. The clarifier collects the remaining solids and pumps them back to the closed tidal cell. 
Stage 6: Horizontal Flow Wetlands

In the final stage of the Living Machine, horizontal flow wetlands are used for the final polishing of the water. One bed (typically simulating marshland qualities) is required for this stage but many living machines have multiple beds as the water quality increases with their number. After this stage, the water can be returned to the landscape or water system, or can safely be used as grey water.

While Living Machines vary in terms of stages, they all consistently carry out the same basic processes of sedimentation, filtration, clarification, adsorption, nitrification, gentrification, volatilization, and anaerobic and aerobic decomposition. (EPA, 2007) 


\section{PHYTOREMEDIATION}

Phytoremediation describes the treatment of environmental problems through the use of mitigating plants without the need to excavate the contaminant material and dispose of it elsewhere. In particular, "this process is accomplished with specific plants that are able to contain, degrade or eliminate metals, pesticides, solvents, explosives, crude oil and its derivatives, and various other contaminants from the media that contain them." (Baker, 2004) Phytoremediation was originally being tested in 1990 but since then has been successfully implemented in over 200 different sites worldwide. It has proved to be highly effective in the remediation of abandoned metal mines and factories and specifically in removing lead, uranium, arsenic and other industrial chemicals.

Hyperaccumulators are plants that are not only able to survive in soils that contain high levels of metal and other toxins, but are typically able to extract toxins and leave the environment in a less toxic state. Many plants are resilient to toxins, but only a few are defined as a hyperaccumulators according to Baker:

A plant is said to be a hyperaccumulator if it can concentrate the pollutant in a minimum percentage which varies according to the pollutant involved (for example: more than $1000 \mathrm{mg} / \mathrm{kg}$ of dry weight for nickel, copper, cobalt, chromium or lead; or more than 10,000 $\mathrm{mg} / \mathrm{kg}$ for zinc or manganese). (Baker, 2014)

Numerous types of Hyperaccumulators have been identified, including over 150 varieties of flowering plants as well as ferns, mustard plants, hemp, pigweed and alpine pennycress, to name a few. 
There are some potential disadvantages for using Phytoremediation. The actual process of phytoremediation takes a considerable amount of time. Although each site is unique, rough estimates range from 15 to 30 years to fully remediate a toxic site. Moreover, as a relatively new technology, there remains a number of unknown factors and consequences. For instance, the extent to which leaves, wood, or other by-products of the hyperaccumulators contain contaminants is undetermined. Depending on the environment, contaminants in the hyperaccumulators can be passed on to the local wildlife. Additionally if the contaminant concentrations are too high,. There also is the question of how to dispose of the highly toxic plants once site remediation has been successfully achieved. As a result, a lot of research, analysis and experimentation is required before a successful solutions in site remediation can be achieved.

There are, however, many advantages for using phytoremediation versus other methods of toxin removal. It is by far the most cost efficient method of toxin removal, and it is visually appealing. In many cases, native plants have been highly successful and thus phytoremediation provides an opportunity to bring back the natural heritage of the affected site as well as restoring biodiversity. 


\section{THE LiVing WATER GARDEN IN CHENGDU, CHINA}

The primary programming of the port in Duisburg Germany will be the living machine, which will not only treat the sewage produced by the river barge and community of Duisburg but will also serve to cleanse the water of the Ruhr and Rhine Rivers. The Living Water Garden in Chengdu, China is therefore an important precedent to study.

Chengdu is a densely populated city in central China with approximately 11 million people and located on the very polluted Fu and Nan Rivers. It was built by The Chengdu Fu \& Nan Rivers Comprehensive Revitalization Project, a five-year plan to rebuild Chengdu's infrastructure to support its growing population for the next 200 years. The Living Water Garden is a landscape park that was designed by American artist Betsy Damon and American Landscape Architect Margie Ruddick.

The six-acre Living Water Garden is a fully functional water treatment plant that treats approximately 200 cubic meters of polluted water a day. While this is not enough to affect the overall quality of the Fu and Nan Rivers, its primary function is to bring awareness to water quality issues and serve as a fully functional environmental education centre:

The park design centers on filtering polluted river water through a series of aeration surfaces, constructed wetlands and water features that enable people to observe how these natural processes can remove pollutants from the river. Visitors can step down to the river, along terraces that also allow the river to flow into the park; they can stroll along the riverbank or sit in an amphitheatre on the river edge. (Place Design Awards, 2013)

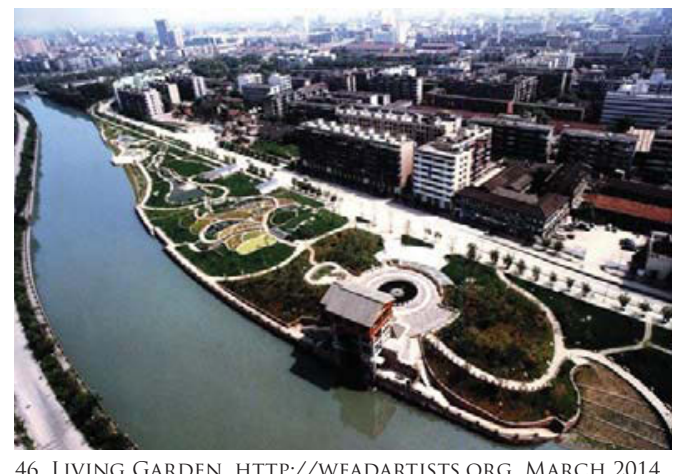

46. LIVING GARDEN, HTTP.//WEADARTISTS. ORG, MARCH 2014 
From above, the park resembles a giant fish (figure 46), The water is first pumped into the eye of the "fish", working its way through the entire garden, while being subjected to numerous filtration processes throughout the sculptural fish, before returning to the river cleansed of pollutants. Throughout the garden the public is encouraged to engage with the water and the landscape through an education centre, an amphitheatre and interactive water sculptures (figures 47,48 ).

The Living Water Garden is successful in reconnecting people with nature and also drawing attention to water quality issues.

The Living Water Garden proves that people around the world will care about their natural resources when they are given the chance to experience, enjoy and appreciate those resources. When the cultural significance of a river is restored, when the water is no longer a forgotten channel of dirt and grime, when the river is once again a gathering space and a giver of life, then people will cherish and protect it like the great resource that it is. (Place Design Awards, 2013)

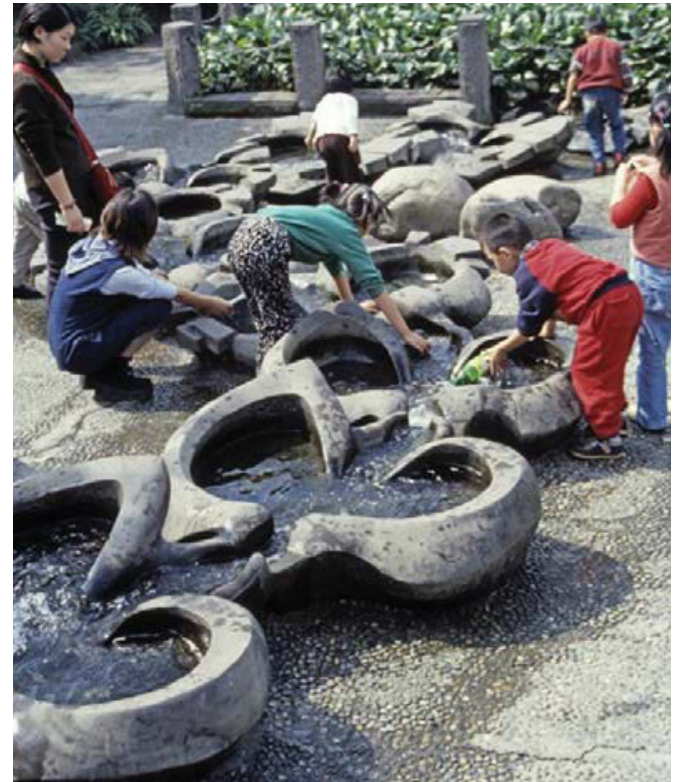

47. DAEMON, HTTP://WEADARTISTS.ORG, MARCH 2014

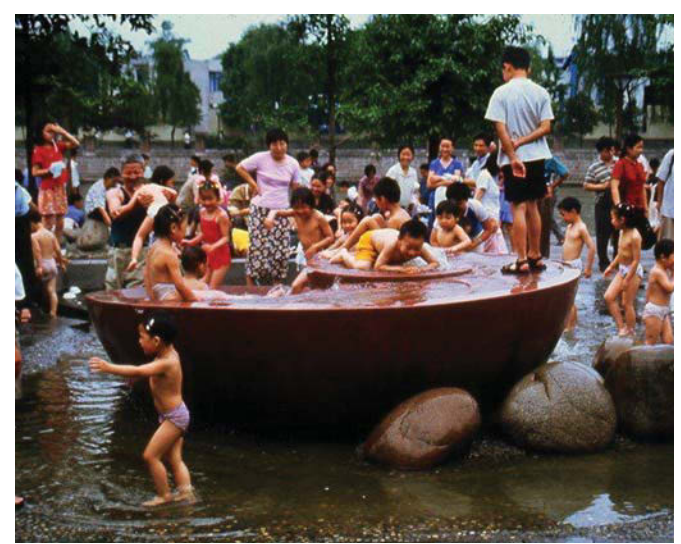

48. LIVING GARDEN, CODAWORX.COM MARCH 2014 


\section{VIKING RIVER CRUISES}

Given that the redesign of the barge and port will be located in Germany, it is important to include a study of Viking River Cruises, a company more closely related than large ocean cruise liners to developing a sustainable tourist network in Duisburg. In addition to larger ocean vessels, Viking River Cruises offers smaller longships that navigate various rivers around the world, including the Rhine. With a main operational headquarters in Basel, Switzerland, and established in 1997, Viking River Cruises boasts cruise ships that, "are destination-focused and carefully crafted with a mix of cosmopolitan and smaller ports of interests" (Viking River Cruises, 2013). The company claims to offer a more authentic way of travelling and experiencing place:

Itineraries are specifically designed to offer longer hours in port than competitors, including late evening stays and overnights to take advantage of night life in select ports, and river cruise itineraries are similarly planned. The company also ensures a focus on enrichment through shore excursions by local guides, regional foods, and privileged access for in-depth exploration of the destinations. All Viking cruises include the exclusive Viking Culture Curriculum program that brings history and culture to life through onboard enrichment lectures; language classes; hands-on cooking demonstrations an classes; and local entertainment to complement included shore excursions. (Viking River Cruises, 2013)

Designed by naval architects Yran \& Storbraaten, a design firm based out of Oslo, Norway, Viking River Cruises claim their vessels provide passengers with numerous sailing accommodations. Typical river cruise ships that follow Rhine itineraries can accommodate between 150-200 passengers. The majority of the Viking Line Cruise ships claim to be environmentally responsible citing energy-efficient hybrid engines, the use of solar panels and

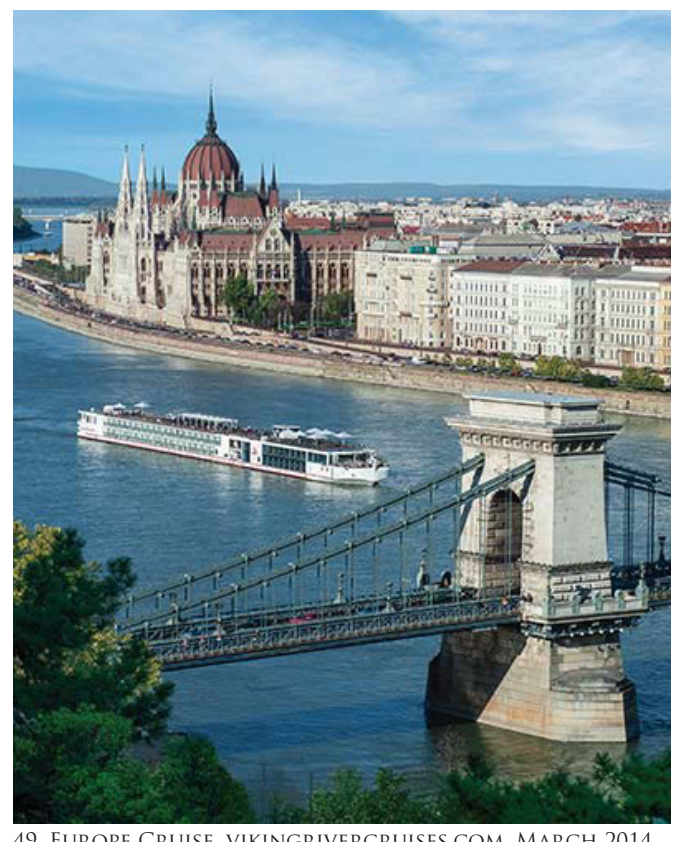

49. EUROPE CRUISE, VIKINGRIVERCRUISES.COM, MARCH 2014 
the inclusion of an organic herb garden. When questioned about their environmental practices, Viking River Cruises addressed the issue by stating:

Our ships have the most stringent emission standards, a hydro-dynamically optimized streamlined hull and bow for maximum fuel efficiency, onboard solar panels, and equipment that minimizes exhaust pollution and meets the strictest environmental regulations. (Viking River Cruises, 2013)

With regards to grey water treatment, Viking River Cruises state that grey water is treated onboard and after being treated, it is released. While this exceeds standards set by Germany, which are stricter than North America, releasing grey water is never positive.

Viking Cruise Line appears to be following much stricter regulations then the majority of the major cruise ship lines and is a better environmental steward, but like Slow Tourism this is not a sufficient model for the future. Viking Cruise lines is still based on the model of tourists taking from the land they visit and not giving back anything besides financial contributions. In order for tourism to be truly sustainable in the future, a more reciprocal relationship is needed whereby the tourist plays the role of contributor. 


\section{CASE STUdies CONCLUSION}

The Duisburg environment is highly contaminated and suffers from chronic pollution from years of heavy industrialization. Given the objectives of the proposed new form of tourism, the main intention behind the port design is to benefit the community of Duisburg and its local environment, including the Ruhr and Rhine Rivers. In keeping with its educational intentions, the proposed port program will incorporate an information centre for the adaptive reuse projects in the Ruhr region. It will also include a living machine that will not only manage the waste created by the cruise industry but also assist with the sewage treatment in Duisburg. Finally it will employ phytoremediation techniques to fully clear the site of contaminants. The port design will not only strive to decontaminate the existing site but will also serve as a catalyst for the revitalization and decontamination of Duisburg for years to come. 


\section{CHAPTER 4 - DESIGN CRITERIA}

The design for the new tourist port in Duisburg, Germany provides a new model for those wishing to participate in a more ethical form of water travel. At the most fundamental level it addresses issues of reciprocity and education.

\section{RECIPROCITY}

Reciprosity: The idea that the tourist industry should give more to the host location than it receives back. In this case:

1. Stimulated by the need to deal with sewage produced by the tourists, it offers an infrastructure that provides water treatment for the local population as well;

2. Rather than a one-way relationship of tourists taking from the local population and only providing monetary value, the locals are invited to share events offered by the tourist vessel via the inclusion of the restaurant progamming on the barge.

3. The infrastructure needed for the tourist vessel's primary function is to improve the public space of the city, even when the tourists are not in port. 


\section{EDUCATION}

Education: the idea that the tourist industry offers an opportunity for discourse regarding sustainable development and design. In this case:

1. The selection of this inceptive site celebrates Duisburg as a centre for innovative adaptive reuse projects and a model for industrial land remediation;

2. The specific site of Holzenhafen uses similar strategies to address the abandoned project by Norman Foster: retaining a memory of the original water edge, speaking to the idea of a river as a natural water treatment element;

3. The adapted design of the barge will serve to educate the tourists and the local population as to environmental issues regarding water travel;

4. Through the accessibility, visibility and elaboration of the processes of the living machine and constructed wetlands, educating both tourists and locals about alternative and more sustainable ways to treat water and rejuvenate polluted waterways. 


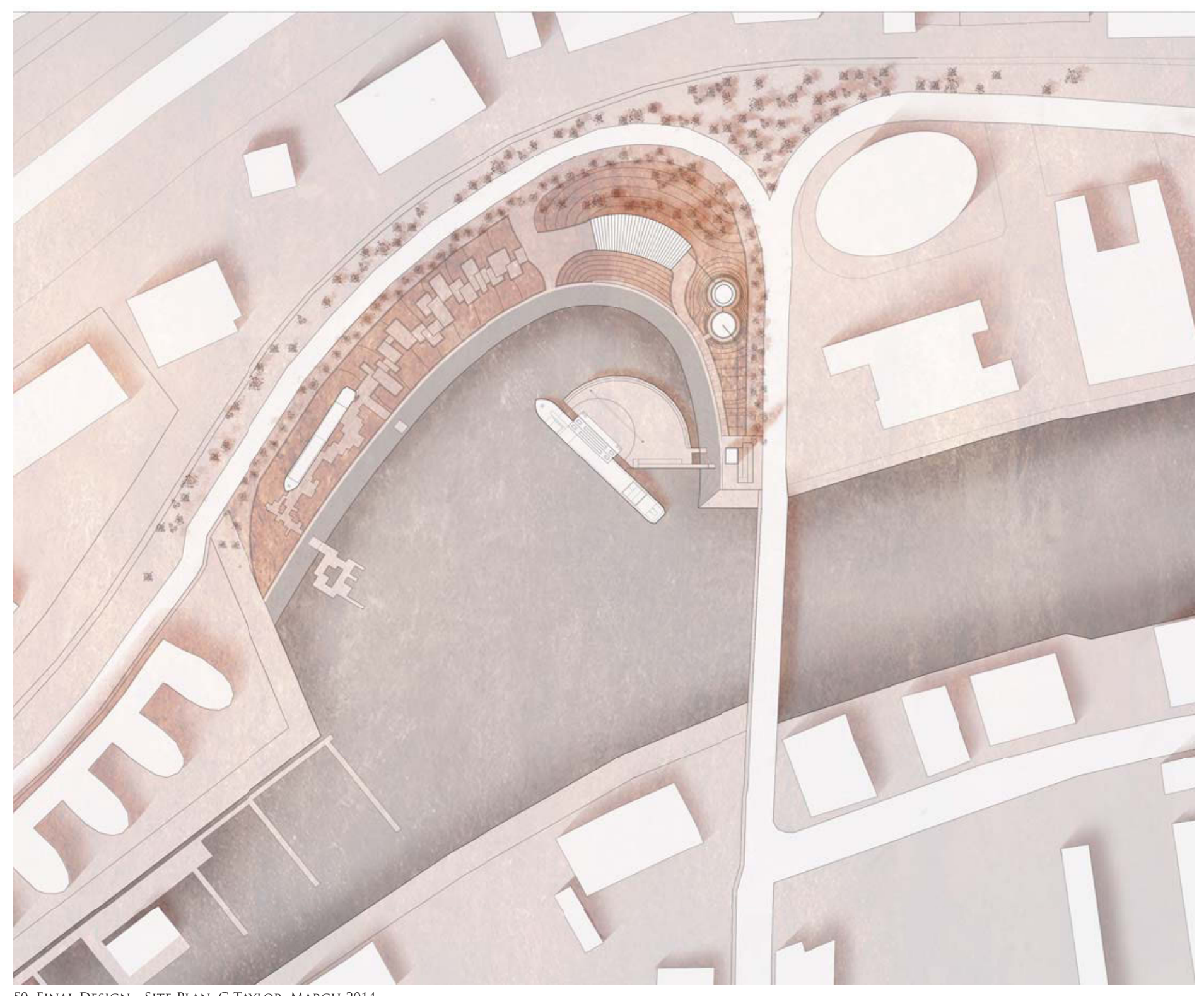



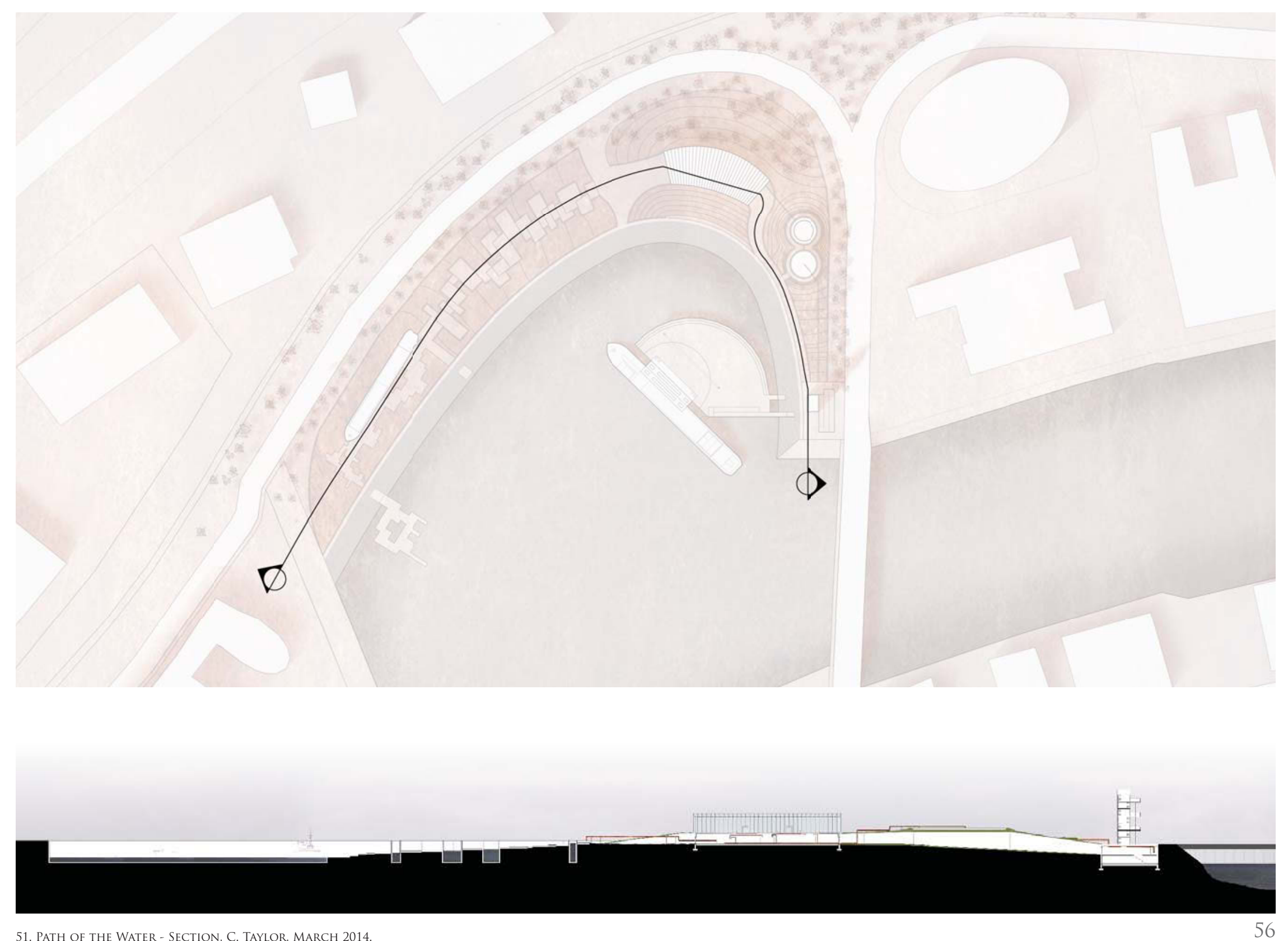


\section{CHAPTER 5 - DESIGN}

\section{FOLLOWING THE PATH OF THE WATER}

The living machine addresses the two main objectives of the new tourism model: that the land-based tourism program be beneficial to the local community and that it be environmentally sustaining. In addition, it provides an opportunity to include important educational opportunities. From the passenger vessel dock, tourists and community members are directed along the site following the path of the contaminated influent through the cleansing stages to its return to Duisburg's Inner Harbor as cleansed water. (figure 51)

Essential to the educational aspect of the living machine is the visibility of each stage of the process. Visitors to the site are able to see the contaminated affluent being pumped from the tourism vessel through exposed piping, past the visitors centre and observatory tower to the first stage, the Anaerobic Reactor. (figure 52) Anaerobic Reactors are typically kept underground for technical or logistical purposes; additionally they are not aesthetically pleasing. For practical purposes the Anaerobic tanks will be kept underground but made visible via a glass roof.

After passing through stage 1, visitors are directed to the green house via a path in the landscape where stages 2-5 occur. Here, individuals access the greenhouse on the second level giving them optimal visibility of the green tidal cell tanks below as well as making visible other processes that are housed in the green house (figure 53). The green house also serves as the circulation hub of the site, allowing users cross-access to the main road, the path of 

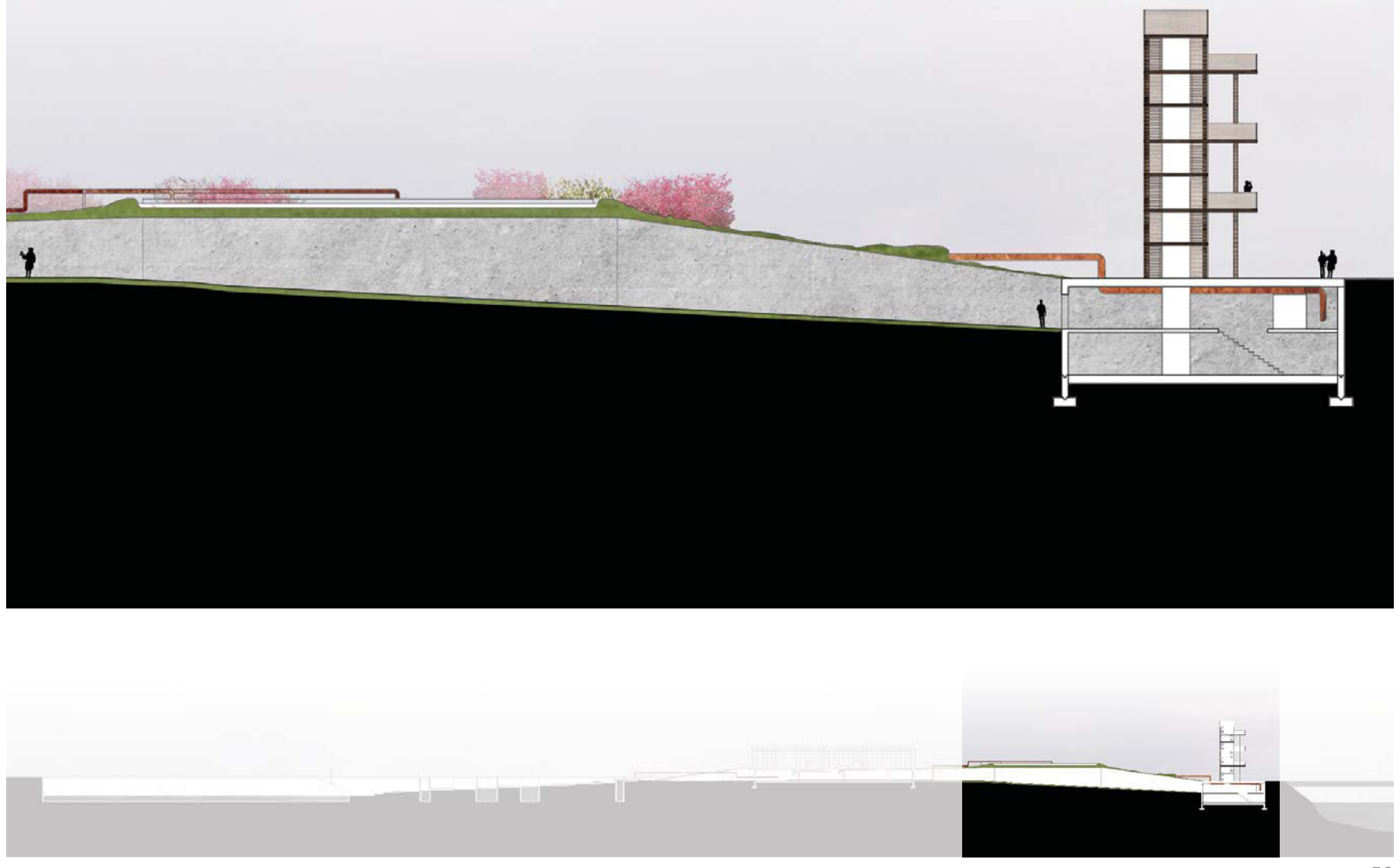

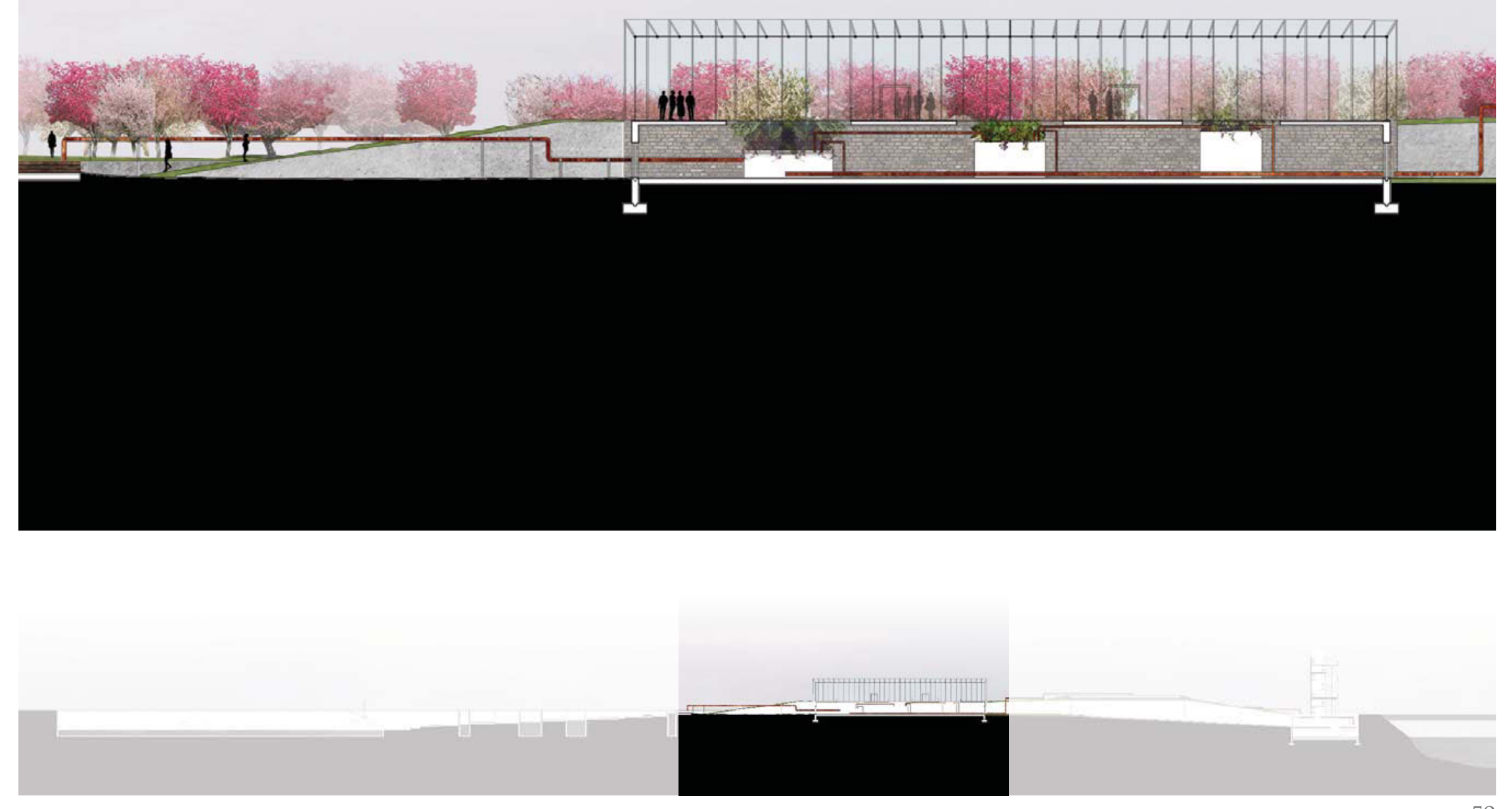
the water and the stepped promenade area.

Continuing on from the green house, visitors are guided to the horizontal flow wetlands, step 6 (figure 54). Here visitors enter the pathway and slowly descend below the water level through a series of shallow steps as the water moves slowly through a series of tiered water beds. The walkway will be constructed using reclaimed wood and will include glass reveals that allows the viewer to experience the cross section of the wetlands giving them an understanding of the water condition.

From here the visitor is directed to an additional reed bed, which is the final stage of the living machine. Users will experience this space through the use of a wharf and a docked historic barge that is no longer used to ship materials along the Rhine. A cut is made through the stepped promenade and the wharf extends into Duisburg's Inner Harbour so that the visitor can see the cleansed water return into the harbour (figures 55 and 56). 

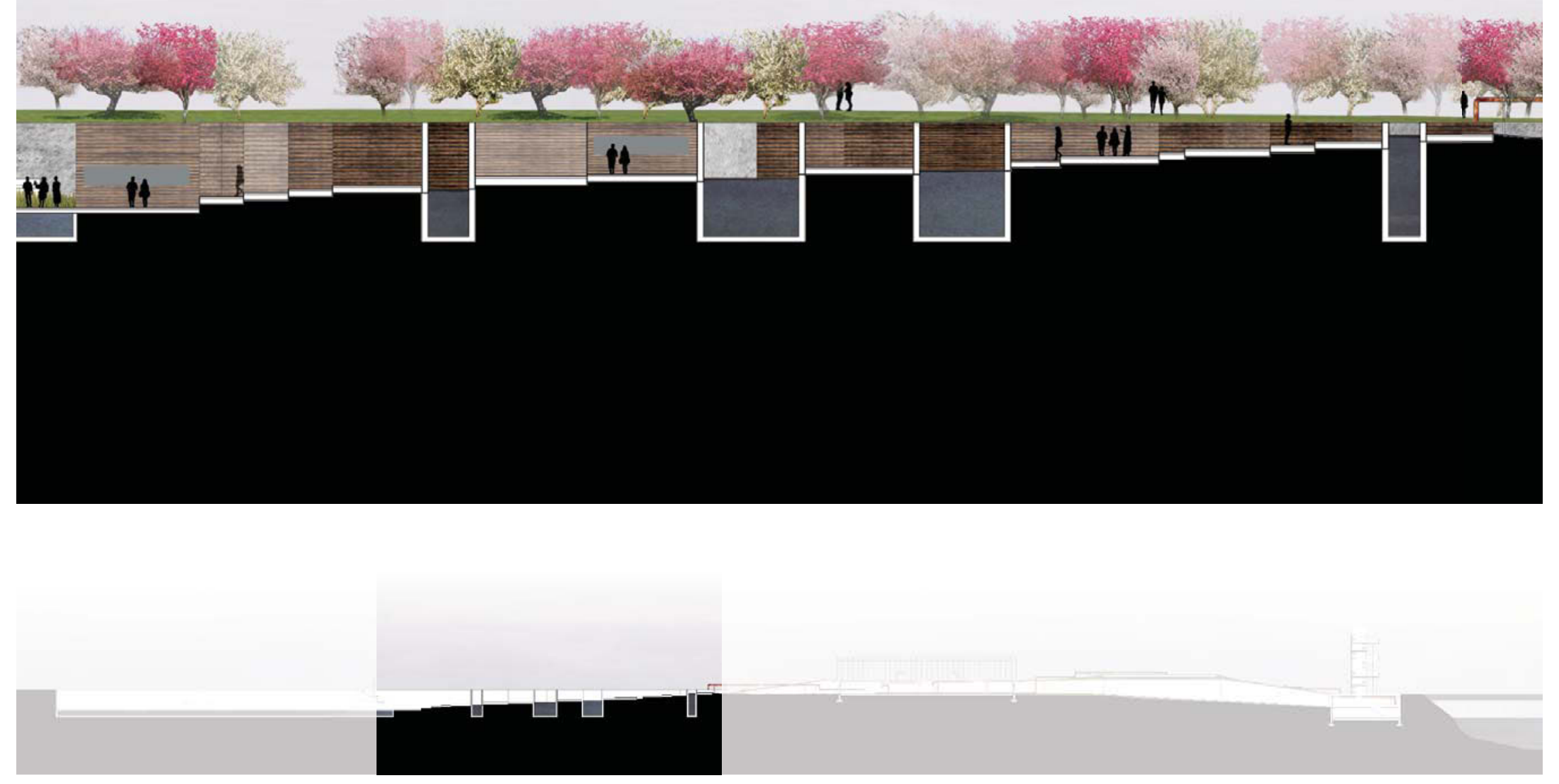

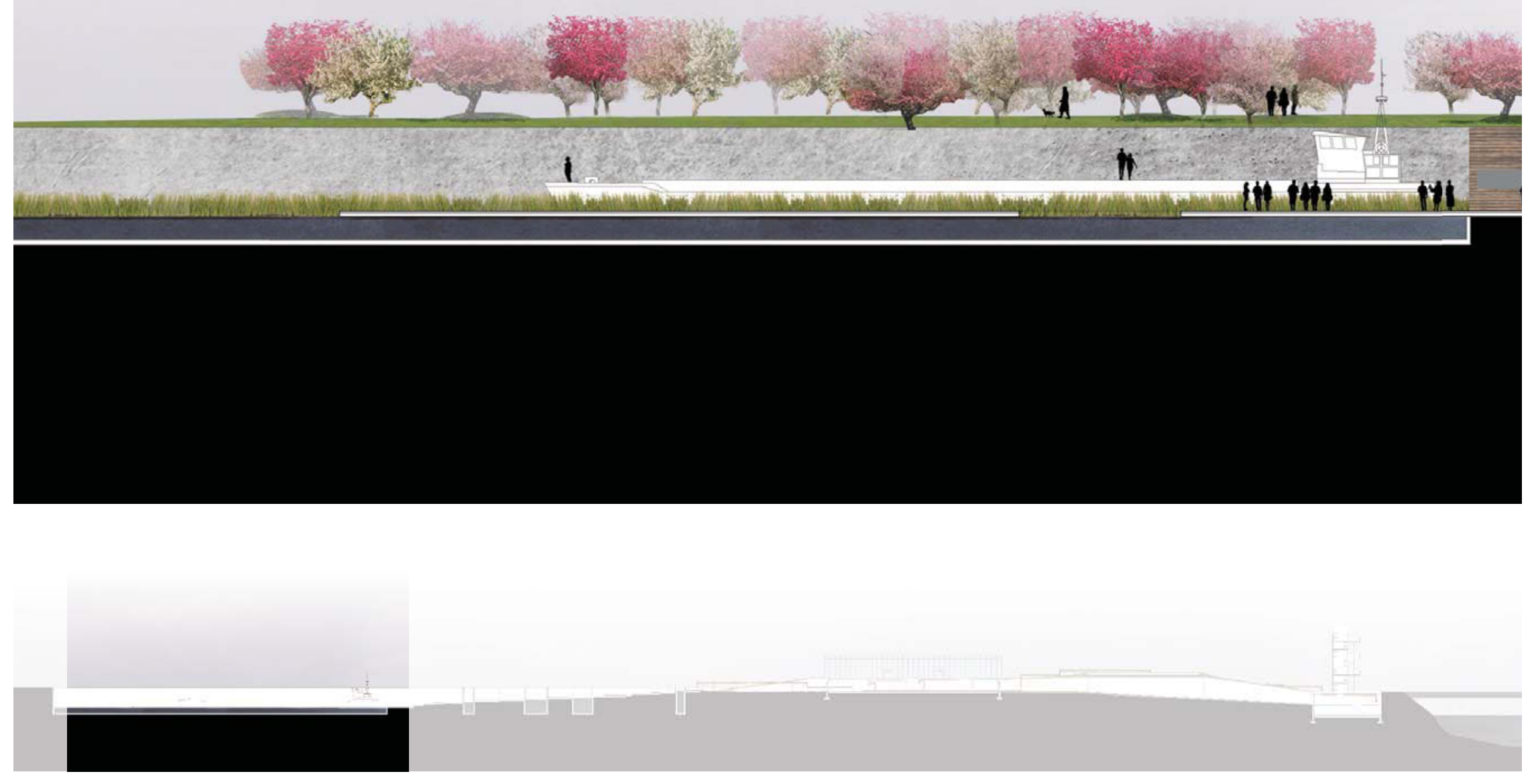

55. Path of the Water - Final Reed Bes and historic barge, C. TAylor, March 2014. 


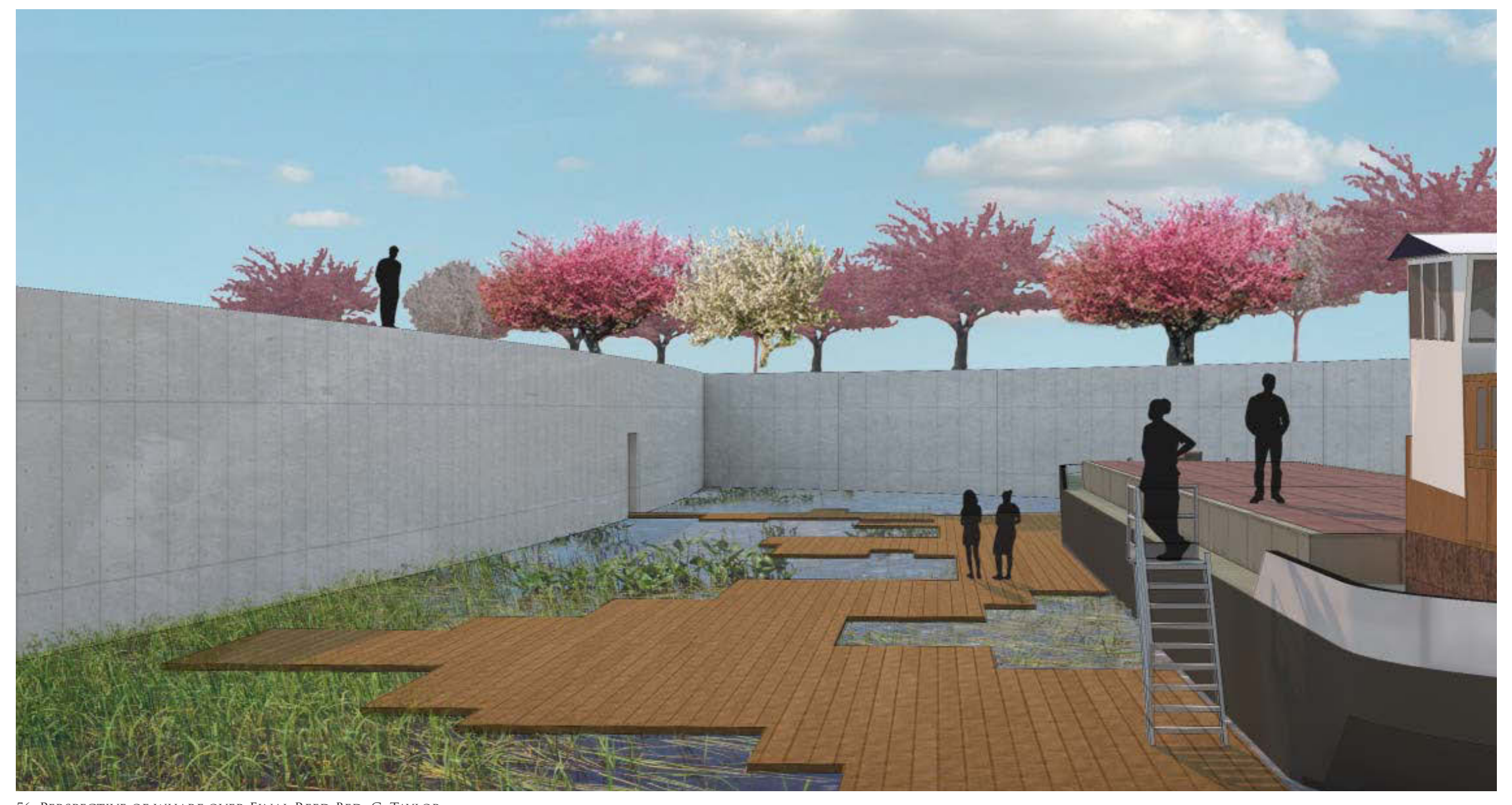

56. Perspective of wharf over Final Reed Bed, C. Taylor, 
Given that the site is located along a very busy road, careful attention was paid to the urban context and how to address this boundary. This led to the redesign of the existing standard size and unused sidewalk to a new 7 meter green orchard pathway that outlining the site. This particular location is highly contaminated with Cadmium, and Duisburg as a whole is polluted and would benefit from the inclusion of phytoremediation. The intention is that this green pathway could serve as a hub that would extend throughout the city and over time become the vegetational vernacular of the area. Figure 58 shows the orchard phydoremediated pathway and green house in perspective.

Trees are commonly used for phytoremediation as they are fast growing, have roots that extend deep into the soil and use a lot of water. Traditionally Poplar trees have proven to be very effective remediators, however local species of trees have proven to be successful and help restore the site's previous biodiversity. Willows, Cherry Blossoms and Mulberry therefore should be considered for this area of Germany as they are native species.

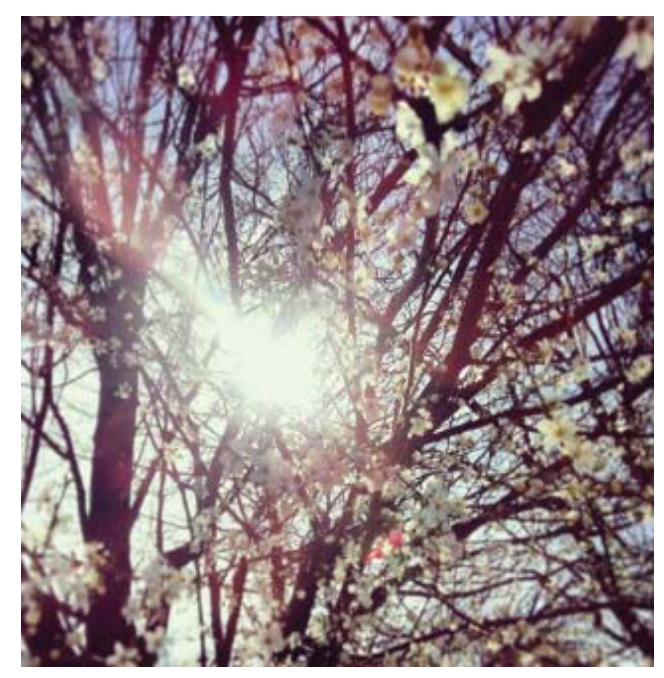

57. Local Flowering Tree. C. TAYlor, Feb 2014 


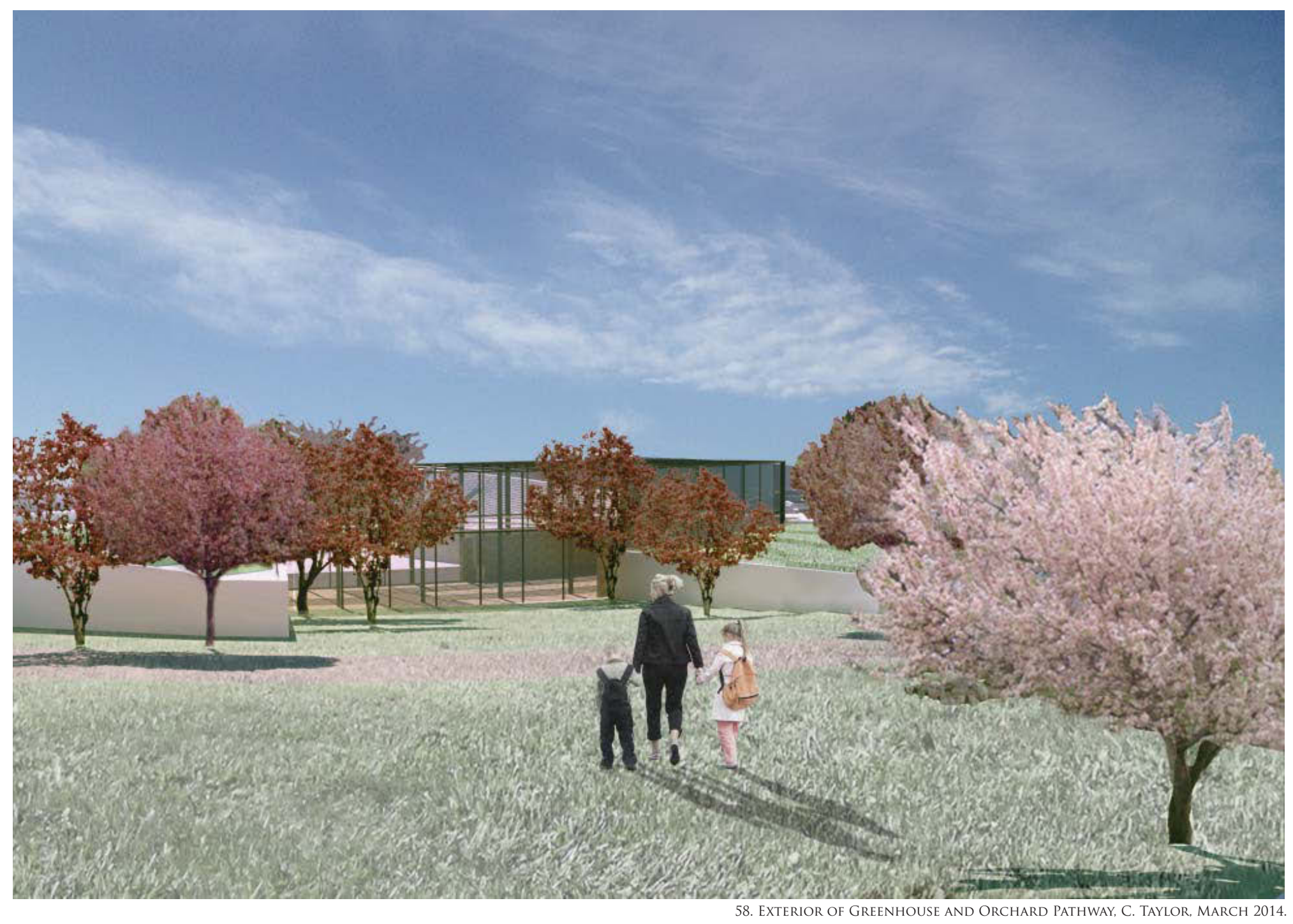


Duisburg's close proximity to the Rhine and the Ruhr rivers make it an ideal location for the passenger vessel to stop along Europe's most important waterway. The Rhine River is very wide; its size allows for sea going vessels to enter into Europe's mainland, making it Europe's busiest waterway. The Ruhr is significantly smaller; this constraint set the initial parameters for the design of the proposed tourist vessel. The vessel I chose to redesign adheres to the classification IV size limitations iin order to travel along the Ruhr River (figure 59).

The three primary design criteria for the passenger vessel are:

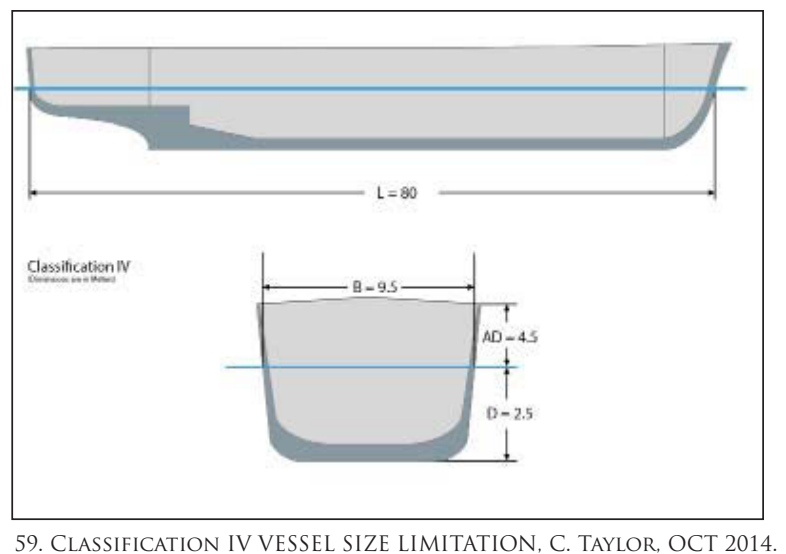

1) Ensuring the project is environmentally responsible

2) Ensuring authenticity in the experience of the journey

3) Fostering positive interactions between the local environment and travelers aboard the vessel

Programming and design should address all of these principles to ensure the success of this project. 
The most important aspect of these criteria is the emphasis on a responsible or ethical way of travelling with concern for the environment. Using the traditional cruise ship to highlight the pitfalls of water-based tourism, this design focuses on addressing issues of waste treatment and water consumption. Specifically, the main concern is to properly address the treatment of black/grey water, oily bilge water, and various other toxins. This polluted water will be stored in visible containers, and the process of pumping the sewage off of the barge to the Living Machine holding tanks will be equally visible.

Design elements that draw the attention of the passengers to the issue of sustainable water consumption will also be incorporated. This will include a transparent water tank visible from the common spaces on the main deck. Making visible the amount of available clean water will make passengers more aware of the water that they consume, with the hope of altering their habits.

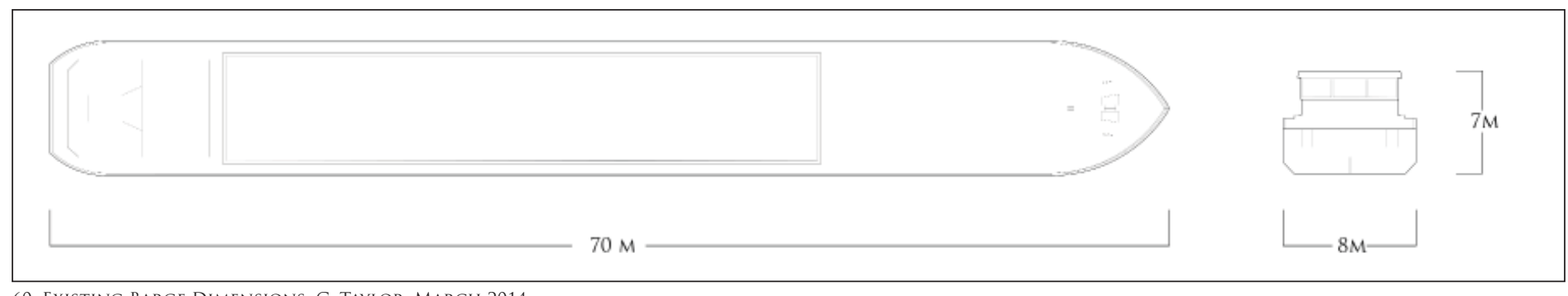

60. EXISTING BARGE DIMENSIONS, C. TAYLOR, MARCH 2014 


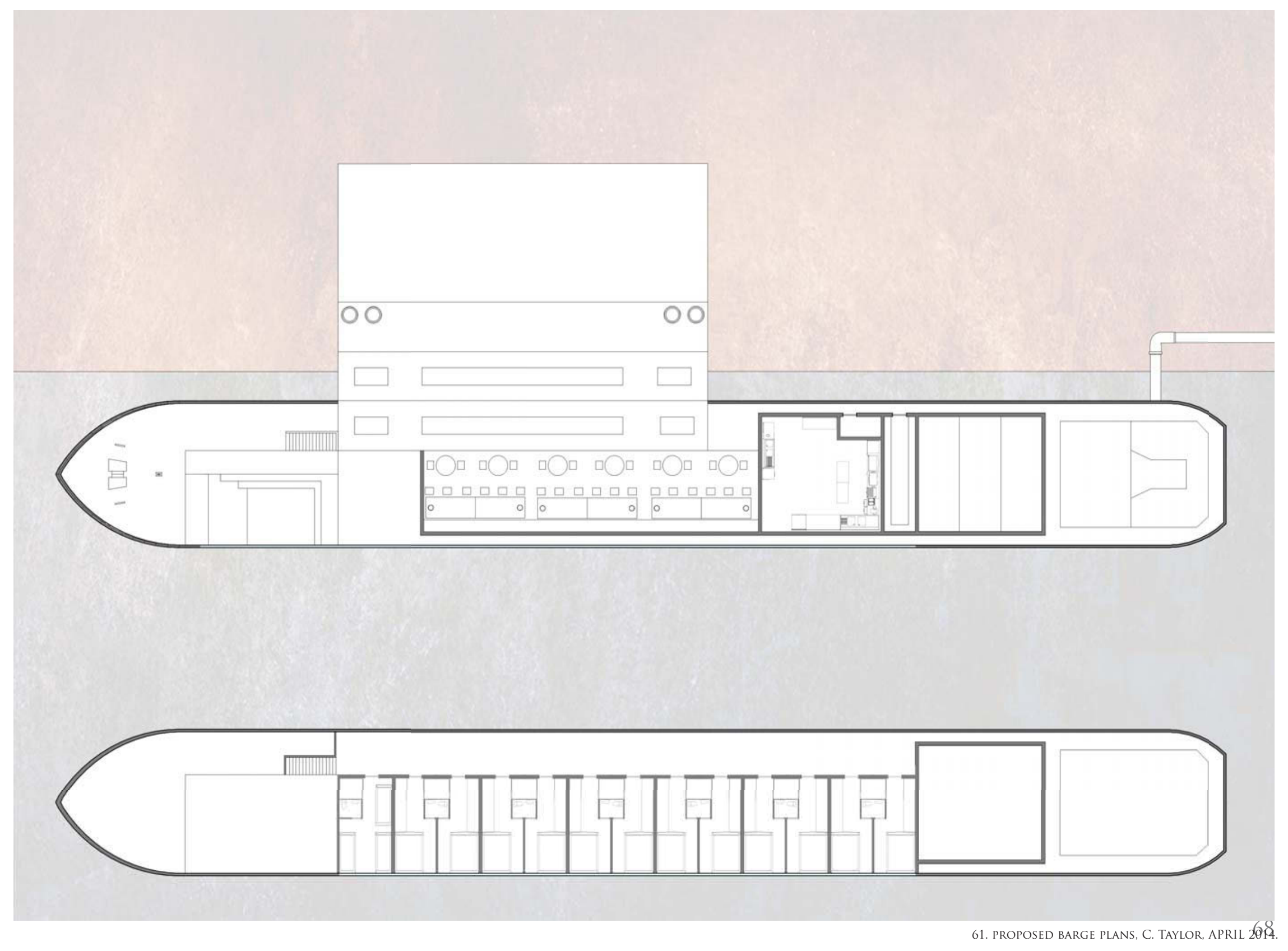


The very limited experience of place afforded by the cruise ship industry is extremely problematic. Passengers onboard often do not have time to engage with the ports they visit, and activities and interactions at ports are typically arranged by the cruise ship. The interaction or experience of the passenger and the water they are travelling on is also lacking due to the design of the typical vessels operated by the cruise ship industry. Cruise ships exist as floating luxury hotels and are fundamentally not designed with location in mind.

In contrast to the isolating nature of cruise ships, the proposed design intends that tourists fully experience the environments through which they travel. Considering the Rhine and the Ruhr both have such a unique history, it is important that those travelling on the barge are well connected to the river. The rivers should be ever present in the traveler's barge experience. This will be addressed in a number of ways. For instance, this project's design will prioritize the location of the individual rooms so that the passengers are able to fully experience the Rivers. (figure 61)

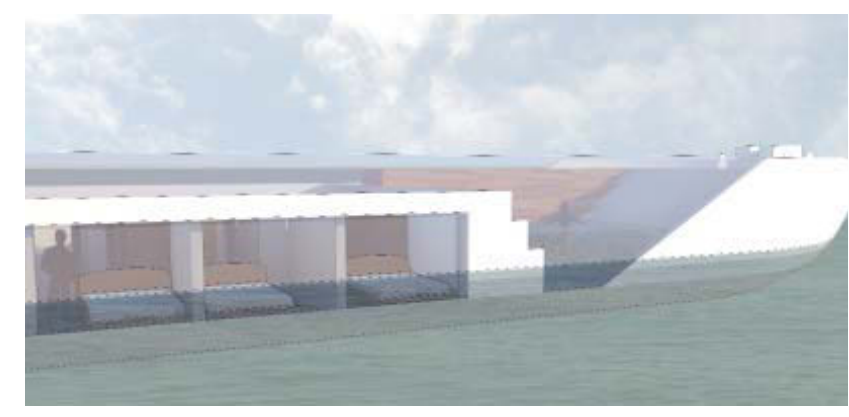
62. INDIVIDUAL CABIN AND HOt TUB CONNECTION WITH WATER C. TAYLoR, MARCH 2014. Additionally the loation of the hot tub on board (its proximity to the water) as well as it's transparent side will connect the passangers to the water. (figure 62) 
The emphasis of this proposal is to foster a mutually beneficial relationship between the tourist and the host city. The redesign of the Holzenhafen focuses on creating a space that is primarily beneficial to the residents of Duisburg. To this end, in addiciton to the programming of the Living Machine, the design of the port will include a programmed pedestrian space that can serve as a market while the vessel is in port and allows the vessel to open its restaurant space to the local population. When the vessel is not in port, the resulting plaza could be used as a performance space, as the stepped promenade provides ideal views and seating.

This amphitheatrical plaza also provides the opportunity for the community to interact with passengers when the vessel is at the port (figure 63). Additionally, the programming on the boat will include a restaurant space (kitchen and dining area) that will be accessible to locals when docked (figure 64). While at port, the restaurant will have access to fresh local ingredients from the market with which to cook while on the river. Furthermore, the passenger vessel will also have the capability to transport goods in extra storage space, taking supplies to and from the market if needed.

In order to foster an inviting interaction between the community at the port and onboard the vessel, a redesign of the boarding plank or ramp was necessary. The intermediary space between the barge and port, which traditionally is a dock or boarding platform, has been widened to include seating to invite a positive interaction 


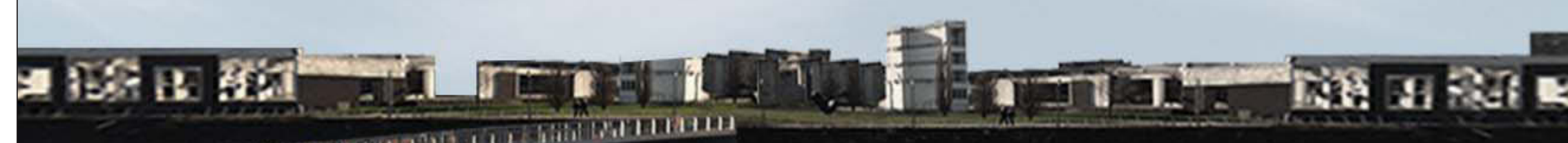

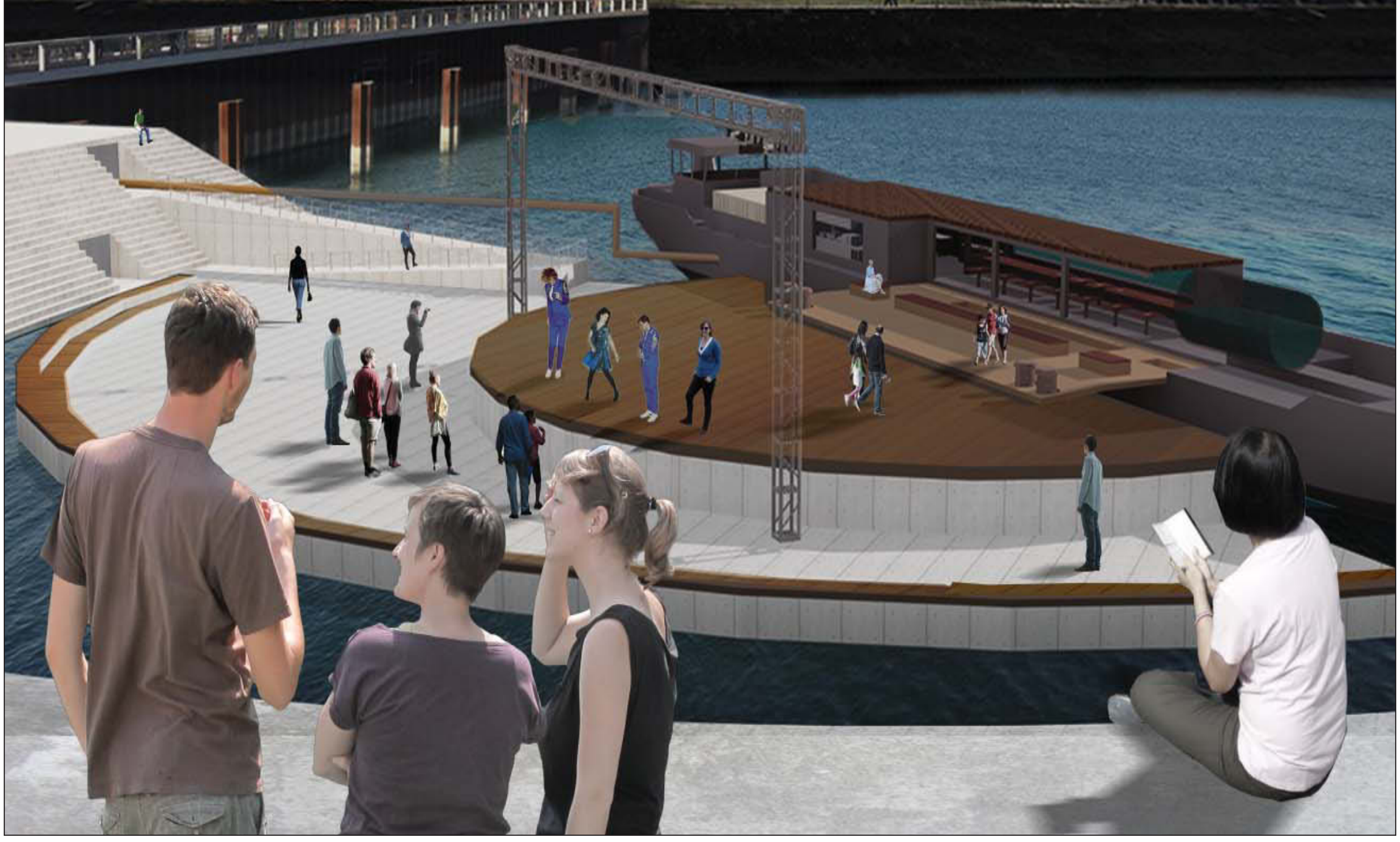




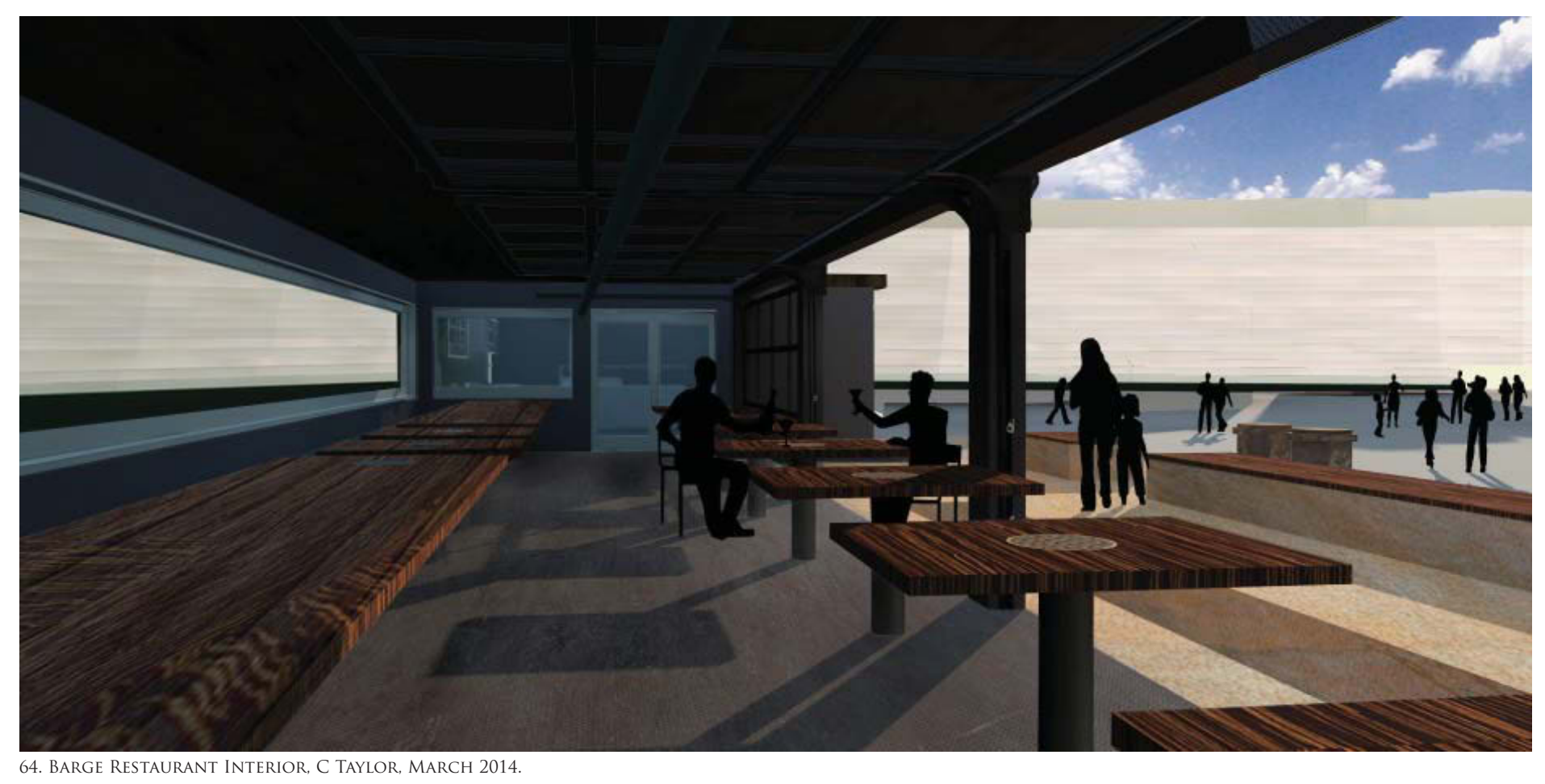


between the two spaces. The pedestrian platform is designed with a stepped section that can serve as a stage and also provides tourists and community members access to the stepped promenade area, the beginning of the pathway of the water and living machine via a ramp, and access to an elevator and a pavilion. 


\section{CONCLUSION}

As demonstrated in the previous chapters, Duisburg, and in particular Holzenhafen, is the ideal location to initiate a shift in the way we think about the cruise tourism industry. Duisburg as it exists today is highly contaminated with lead and cadmium, which is residual from decades of heavy industrialization. (see figues 65 and 66) Were this project to be built, the intention would be for it to serve as a model for future developments along the waterways of Europe. The design criteria for such future developments, as revealed through the design of the Duisburg project, are as follows:

1. Tourism ports should be designed to offer positive contributions to the local population and environment. There are a number of ways that this can be achieved:

To counteract one of the most negative impacts of the cruise industry, that of the production of waste by the tourist population, sustainable ways to address tourism waste treatment should be sought out and combined with local waste water and river water treatment.

Where possible, projects should be located on brownfield sites and adaptively reused existing structures.

Remediation of such sites should be an essential design element in their redevelopment.

Existing cultural and commercial events and activities should be enhanced by the addition of an infrastructure that serves both the tourist and local populations. 


\section{LEGEND}

High LeAD AND CADMIUM CONTAMINATION High Lead Contamination

high Cadmium Contamination

Moderate Lead AND Cadmium Contamination 


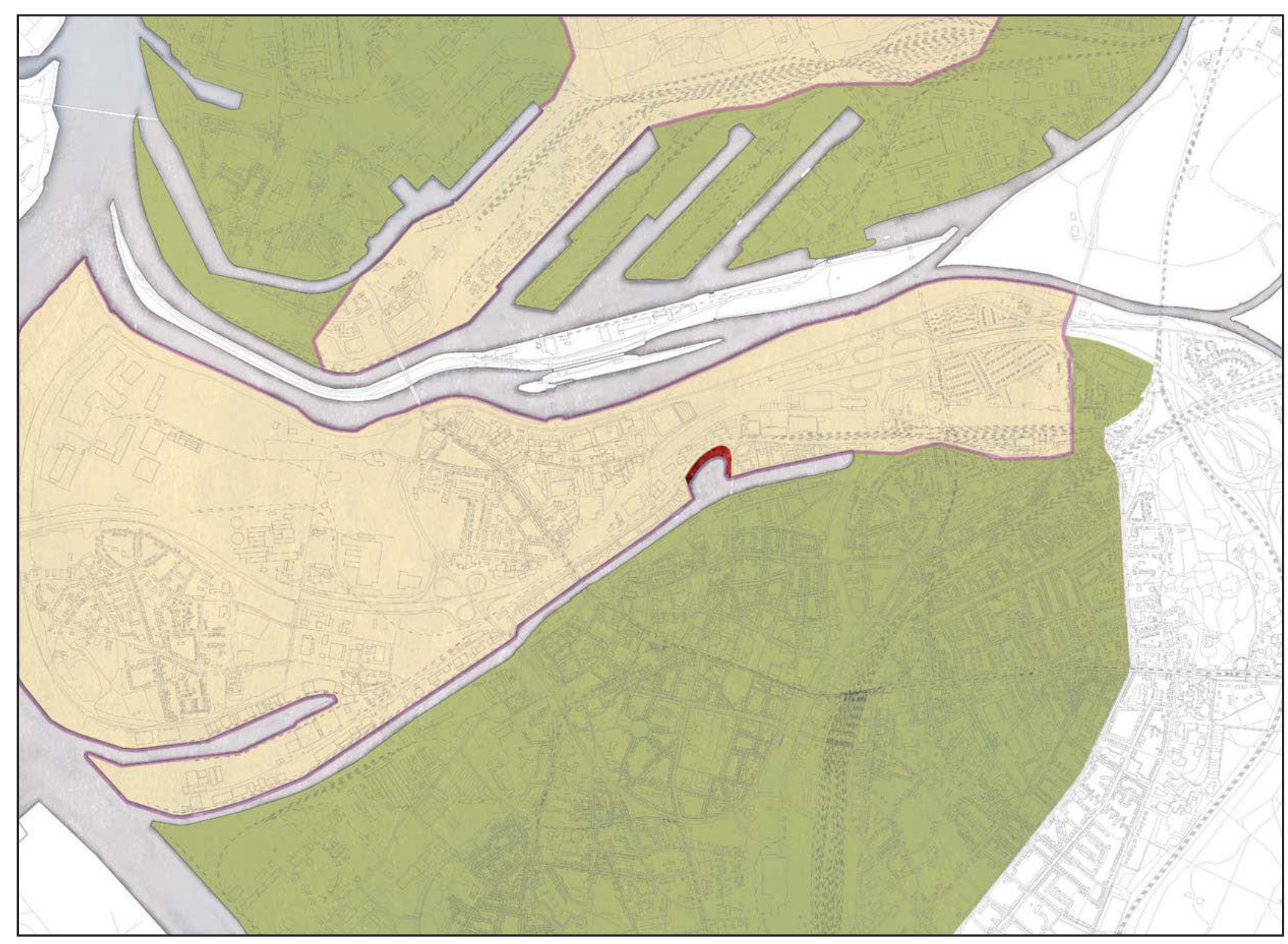

66. POlLution IN DUISBURG, C. TAYLOR, MARCH 2014. 
2. Tourism ports should function as an opportunity for discourse regarding sustainable development and design:

Where possible, sites should be located in visible locations in the host areas and should be tied into local educational and social networks.

Design emphasis should be placed on bringing attention to and making evident sustainable design practices and processes.

Building a greener. more sustainable river or region does not happen overnight. It will take decades for the water treatment and remediation systems to have a tangible effect on the local environment. This project is envisioned as the initial spark of revitalization that will spread first throughout Duisburg then throughout the Ruhr region. As the proposal of a tourist hub and barge in Holzenhafen addresses issues of education and reciprocity through urban planning and design so too could similar future developments, transforming the original rust belt into an area of green adaptive reuse that everyone can travel to, learn and benefit from.

Following this line of thinking, twenty years from now, Duisburg and the Ruhr region would look quite different. While preserving its industrial heritage the Ruhr region would have a fully developed network of orchard paths, revitalized waterways, and projects that help in the natural restoration of previous brown field sites. (see figure 67 for proposed adaptive reuse projects, their effects on the environment and vision of Duisburg in twenty years) Ideally the development of this tourist network would connect similar 


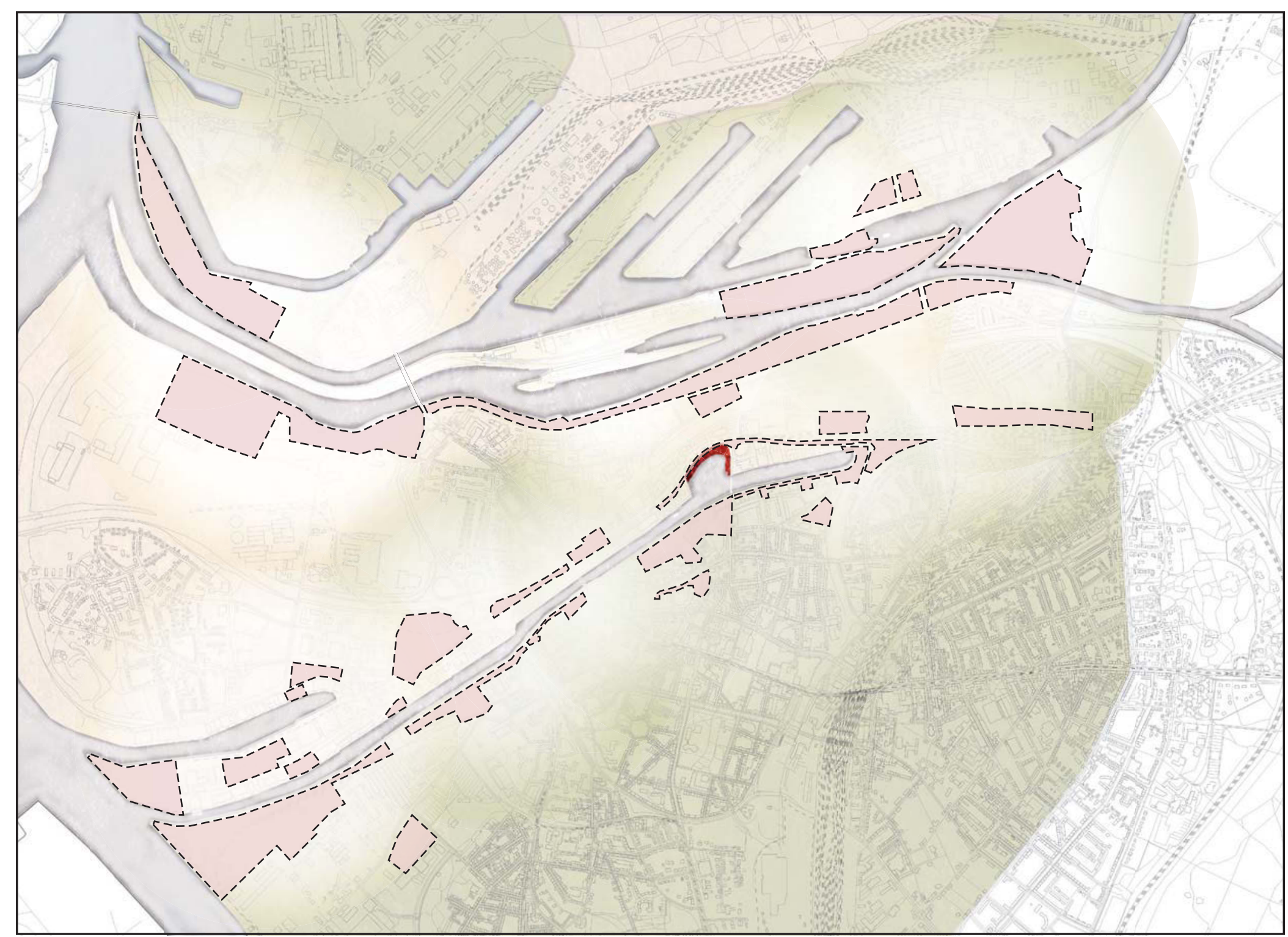

67. The Future Of Duisburg - Site Plan, C. TAYlor, MARCH 2014. 
Our most important responsibility to the future is not to coerce it but to attend to it. Collectively, [such actions] might be called 'future preservation', just as an analogous activity carried out in the present is called historical preservation. (Lynch 1972: 115) 


\section{LIST OF FIGURES}

all images are property of the author unless otherwise stated

* Title Page: InNenhafen Duisburg, htTP://WWW.Fotocommunity.de, FEB 2014

1. TAles on A BACKPACK, C. TAYlor, Feb 2014.

2. HOUSEBOATS UNDER THE MIDNIGHT SUN, C. TAYLOR, JULY 2012.

3. HOUSEBOATS ON GREAT SLAVE LAKE, C. TAYLOR, JULY 2012

4. TOURIST DEVELOPMENT IN RELATION TO ENVIRONMENTAL QUALITY. ASHGATE. OCT 2013.

5. WHY NORWEGIAN, WWW.NCL.COM, MARCH 2014.

6. WHY NORWEGIAN, WWW.NCL.COM, MARCH 2014.

7. NORWEGIAN SPA, CRUISE-INTERNATIONAL.COM, MARCH 2014

8. PRINCESS SHIP DOCKED AT ST. MARTIN, C. TAYLOR, JAN 2014.

9. M.S. BIZET IN PARIS. WWW.CNTRAVLER.COM. APRIL 2014

10. NCL CASINO, WWW.NCL.COM, MARCH 2014.

11. VIKING'S LUXURY INTERIOR, WWW.FROMTHEDECKCHAIR.COM , MAY 2014

12. CARgo Ship, FlightLesstraVEl.COM, MARCH 2014.

13. RHINE RIVER AND BINGEN. HTTP://WWW.WIKIPEDIA.COM. MARCH 2014

14. FULL MAP OF THE RHINE, CIOC 1 , NOV 2013.

15. RHINE AT DUSSELDORF WIKIPEDIA.ORG, MARCH 2014.

16. INDUSTRIES ON RUHR, CIOC 1, NOV 2013.

17. The Rhine at Duisburg, C TAYlor, Feb 2014.

18. RHINE AND RUHr AT DUISBURG, C TAYLOR, FEB 2014

19. ABANDONED BARGE ON RUHR, C TAYLOR, FEB 2014.

20. CONFluence of RHine AND Ruhr, C TAYlor, Feb 2014.

21. THe RuHr, RHine ANd Duisburg - Site Plan, C TAYLOR, MARCH 2014.

22. DUISPORT AND RUHR HTTP://WWW.PORTSTRATEGY.COM, FEB 2014.

23. DUISBURG RECYCLING Plant, C. TAYLOR FeB 2014

24. Men AT WORK, POSTMUSE.CA, FeB 2014.

25. Duisburg InNER HARbour - Site Plan, C TAYlor, MARCH 2014

26. Duisburg inner harbour, C. TAYlor, Feb 2014.

27. HOLZHAFEN PHOTO COLLAGE. C. TAYLOR, FEB 2014

28. Eurogate Site Plan, WWW.Fosterandpartner.COM, Feb 2014.

29. DUISBURG INNER HARBOUR (1900), EN.ACADEMIC.RU, MARCH 2014

30. Eurogate BuILDing Plan, WWW.FosterandPartner.COM, FeB 2014

31. EUROGATE SECTION, WWW.FOSTERANDPARTNER.COM, FEB 2014.

31. Duisburg INNER Harbour (1900), eN.ACADEMIC.RU, MARCH 2014.

32. Holzhafen Stepped Prominade LOOKING EASt, C TAYLOR, Feb 2014.

33. Behind STEPPED Prominade, C TAYlor, Feb 2014.

34. VieW From BRIDGe LOOKING NORTH-WeSt, C TAYLOR, FeB 2014.

35. HOLZENHAFEN - Site Plan, C TAYLOR, MARCH 2014

36. LANDSCHAFTSPARK. HTTP://EN.LANDSCHAFTSPARK.DE, NOV 2013. 2014

37. LANDSCHAFTSPARK DUISBURG-NORD, HTTP://EN.WIKIPEDIA., MARCH

2014

38. COAL BUNKERS . HTTP://EN.LANDSCHAFTSPARK.DE, NOV 2013.

39. GASOMETER. HTTP://EN.LANDSCHAFTSPARK.DE, NOV 2013.

40. GASOMETER DIVER, HTTP://EN.LANDSCHAFTSPARK.DE, NOV 2013

41. Pedestrian Path over Coal Bunkers. C. TAylor. Feb 2014.

42. LIGHT INSTALLATION. HTTP://EN.LANDSCHAFTSPARK.DE, FEB 2014

43. INTERIOR OF FINDHORN LIVING MACHINE. HTTP://WWW.GEOGRAPH.

ORG.UK/, FEB 2014

44. PROPOSAL PLANS FOR LIVING MACHINE AT CARLETON, NOV 2013

45. SCHEMATIC DIAGRAM FINDHORN LIVING MACHINE, HTTP://WWW.THEECOLOGIST.ORG MARCH 2014

46. LIVING GARDEN, HTTP://WEADARTISTS.ORG, MARCH 2014

47. DAEMON, HTTP://WEADARTISTS.ORG, MARCH 2014

48. LIVING GARDEN, CODAWORX.COM MARCH 2014

49. EUROPE CRUISE, VIKINGRIVERCRUISES.COM, MARCH 2014

50. FinAl DESIGN - SITE PLAN, C TAYLOR, MARCH 2014.

51. PATH of THE WATER - SECTION. C TAYLOR. APRIL 2014

52. Path of the Water - Observatory, TOWER, Circulation Hub \& Stage 1 SECTION, C. TAYLOR, MARCH 2014.

53. Path of the Water - Green House Section, C. Taylor, MarCh 2014

54. PATH OF THE WATER - HORIZONTAL FlOW WeTLANDS SECTION. C. TAY-

LOR, MARCH 2014.

55. Path of the Water - Final Reed bes and historic barge, C. TAylor,

MARCH 2014.

56. Perspective of Wharf over Final Reed Bed, C. TAYlor,

57. Local Flowering TREe. C. TAYLOR, Feb 2014

58. EXterior of GreEnhouse AND ORChard Pathway, C. TAYLOR, MARCH 2014.

59. CLASSIFICATION IV VESSEL SIZE LIMITATION, C. TAYLOR, OCT 2014

60. EXISTING BARGE DimENSIONS, C. TAYLOR, MARCH 2014

61. PROPOSED BARGE PLANS, C. TAYLOR, APRIL 2014.

62. INDIVIDUAL CABIN AND HOT TUB CONNECTION WITH WATER C. TAYLOR, MARCH 2014.

63. BARGE AND COMMUNITY INTERACTION, C. TAYLOR, MARCH 2014.

64. BARGE RESTAURANT INTERIOR, C TAYLOR, MARCH 2014.

65. POllution ALONG RHINE, WWW.DUISBURG.DE, MARCH 2014.

66. POLLUTION IN DUISBURG, C. TAYLOR, MARCH 2014.

67. The Future of DuisBurg - Site Plan, C. TAYlor, MARCH 2014

* Final page: Exterior of Greenhouse and Orchard pathway, C. TayLOR, MARCH 2014. 


\section{BIBLIOGRAPHY}

Social, Economic and Political Interrelationships. London [etc.: Routledge, 2006. Print.

Gössling, Stefan, and Colin Michael Hall. Tourism and Global Environmental Change: Baker. Phytoremediation." Phytoremediation Association of Canada. N.p., n.d. Web. an. 2014. http://www.phytoremediation.ca/

Ecological, Social, Economic and Political Interrelationships. London: Routledge, 006. Print.

Callahan, Jeri. Staying Afloat: Life aboard Houseboats, Barges and Liveaboards. Seattle, "Hidden Europe | A Manifesto for Slow Travel." Hidden Europe | A Manifesto for Slow WA: Peanut Butter, 2004. Print.

Cioc, Mark. The Rhine: An Eco-biography, 1815-2000. Seattle: University of Hueting, R., C. Van Der Veen, A. Ch Kiss, and H. U. Jessurun D’Oliveira. RhineWashington, 2002. Print.

pollution - La Pollution Du Rhin. Zwolle: Willink, 1978. Print.

Clark, Jayne. "Disney Earns Top Grade on Cruise Ship Green Report." The Hamilton Hunt, M. "River Cruises." The Travel Foundation. N.p., n.d. Web. 9 May 2014.

Spectator 26 Oct. 2013, Travel sec.: G14. Print.

Coghlan, Francis,et. Al. The Miniature Guide to the Rhine through Belgium and Parklands. N.p., n.d. Web. 3 Dec. 2013.

Holland, Northern and Southern Gerimany: With a Fashionable German Watering Places, Railway Routes, Steam Packets, \&c.; with a Map of Continental Railways and Rhine Panorama. London:, Paris, 1853. Print.

Cooper, M. River Tourism. Wallingford, U.K.: CABI, 2009. Print.

Klein, Ross A. Paradise Lost at Sea: Rethinking Cruise Vacations. Halifax, N.S. Fernwood Pub., 2008. Print.

Dennis, Ben, and Betsy Case. Houseboat, Reflections of North America's Floatin Homes: History, Architecture, and Lifestyles. Seattle, WA: Smuggler's Cove, 1977.
Print. Leslie, David. Responsible Tourism: Concepts, Theories and Practices. Cambridge,
MA: CAB International, 2012. Print.

Dennis, Ben. Houseboat : Reflections of North America's Floating Homes. Seattle Smugglers Cove Pub, 1977. Print.

"The Living Machine: Wastewater Treatment Fact Sheet." United States Environmental Protection Agency. N.p., Oct. 2002. Web. 3 Mar. 2014.

Dickinson, Janet, and Les Lumsdon. Slow Travel and Tourism. London: Earthscan, 2010. Print

"Living Water Park." Place Design Award. N.p.,n.d. Web. 26 Mar. 2014 Mann, Roy. Rivers in the City. New York: Praeger, 1973. Print.

Eadington, William R. Tourism Alternatives: Potentials and Problems in the Development of Tourism

Philadelphia, PA: University of Pennsylvania, 1992. Print.

"Earthship.com | Sewage Treatment." Earthship Biotecture. N.p., n.d. Web. 17 Oct.

Lynch, Kevin. What Time Is This Place? Cambridge: MIT, 1972. Print

Melnik, Anna. A Feasibility Analysis of a Living Machine For ES2. Thesis. Waterloo, 2004. N.p.: n.d. Print.

Niver n.d. Web. 15 Mar. 2014.

"EDF Joins EPA in Announcement of Historic U.S. Action to Protect Americans from Deadly Global Shipping Pollution." US Newswire. N.p., 30 Mar. 2009. Web. 10 Jan.

"EPA." Laws \& Regulations. N.p., n.d. Web. 23 Feb. 2014.

"Foster + Partners." Foster + Partners. N.p., n.d. Web. 1 Feb. 2014.

Smith, Valene L, and William R. Eadington. Tourism Alternatives: Potentials and Problems in the Development of Tourism. Chichester: Wiley, 1994. Print.

"Sustainable Design." Sustainable Sewage Design. N.p., n.d. Web. 17 Oct. 2013.

"Sustainable Solutions for Travelers." Sustainable Travel International. N.p., n.d. Web. 17 Sept. 2013.

Suvantola, Jaakko. Tourist's Experience of Place. Aldershot, Hampshire, England Frey, Beth. Floating Shelter: Living on Houseboats in Europe and North America. Ashgate, 2002. Print. [Cambridge? Mass.]: P. Droege, 1978. Print.

Fullagar, Simone, Kevin Markwell, and Erica Wilson. Slow Tourism: Experiences an Fullagar, Simone, Kevin Markwell, and Erica Wilson. Slow

"This Waste Management Machine Turns Waste Into Drinking Water." TrendHunter

com. N.p., n.d. Web. 17 Oct. 2013.

Gibson, Philip. Cruise Operations Management: Hospitality Perspectives. New York: Routledge, 2012. Print.

"Tourism, Globalisation and Sustainable Development." Tourism, Globalisation and

Gillin, Jaime. "Archite

Waymer, Kim. "Ship’s Soot Deadly, Study Shows." N.p., 17 Nov. 2007. Web. 10 Oct. Web. 25 July 2013.

Gossling, S., and C. M. Hall. Tourism \& Global Environmental Change: Ecological, a Toxic Secret. New York: HarperCollins, 2001. Print. 
